\title{
DIRECTORY TO U.S. GEOLOGICAL SURVEY PROGRAM ACTIVITIES IN COASTAL AREAS
}

1974-76

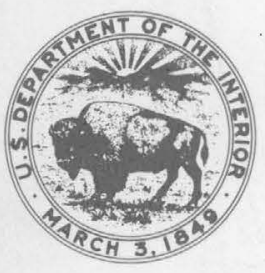

GEOLOGICAL SURVEY BULLETIN 1428 


\section{DIRECTORY TO U.S. GEOLOGICAL SURVEY PROGRAM ACTIVITIES IN COASTAL AREAS $1974-76$}

PHILIP A. MARCUS, EDITOR

GEOLOGICAL SURVEY B ULLETIN 1428

$A$ description of 16 U.S. Geological Survey program activities in Coastal areas during 1974-76

Resources and Land Investigations (RALI) Program

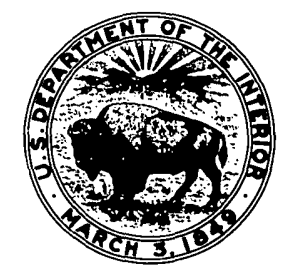




\section{UNITED STATES DEPARTMENT OF THE INTERIOR}

THOMAS S. KLEPPE, Secretary

\section{GEOLOGICAL SURVEY}

V. E. McKelvey, Director

\section{Library of Congress Cataloging in Publication Data}

United States. Geological Survey.

Directory to Geological Survey program activities in coastal areas, 1974-76.

(Geological Survey bulletin; 1428)

Bibliography: p.

Includes indexes.

1. Coasts--Research--United States. 2. United States. Geological Survey. I. Marcus,

Philip A. II. Title. III. Series: United States. Geological Survey. Bulletin; 1428.

QE75.B9 no. 1428 [GB460.A2] 557.3'08s [557'.07'2] 76-23091

For sale by the Superintendent of Documents, U.S. Government Printing Office Washington, D.C. 20402

Stock Number 024-001-02851-4 


\section{CONTENTS}

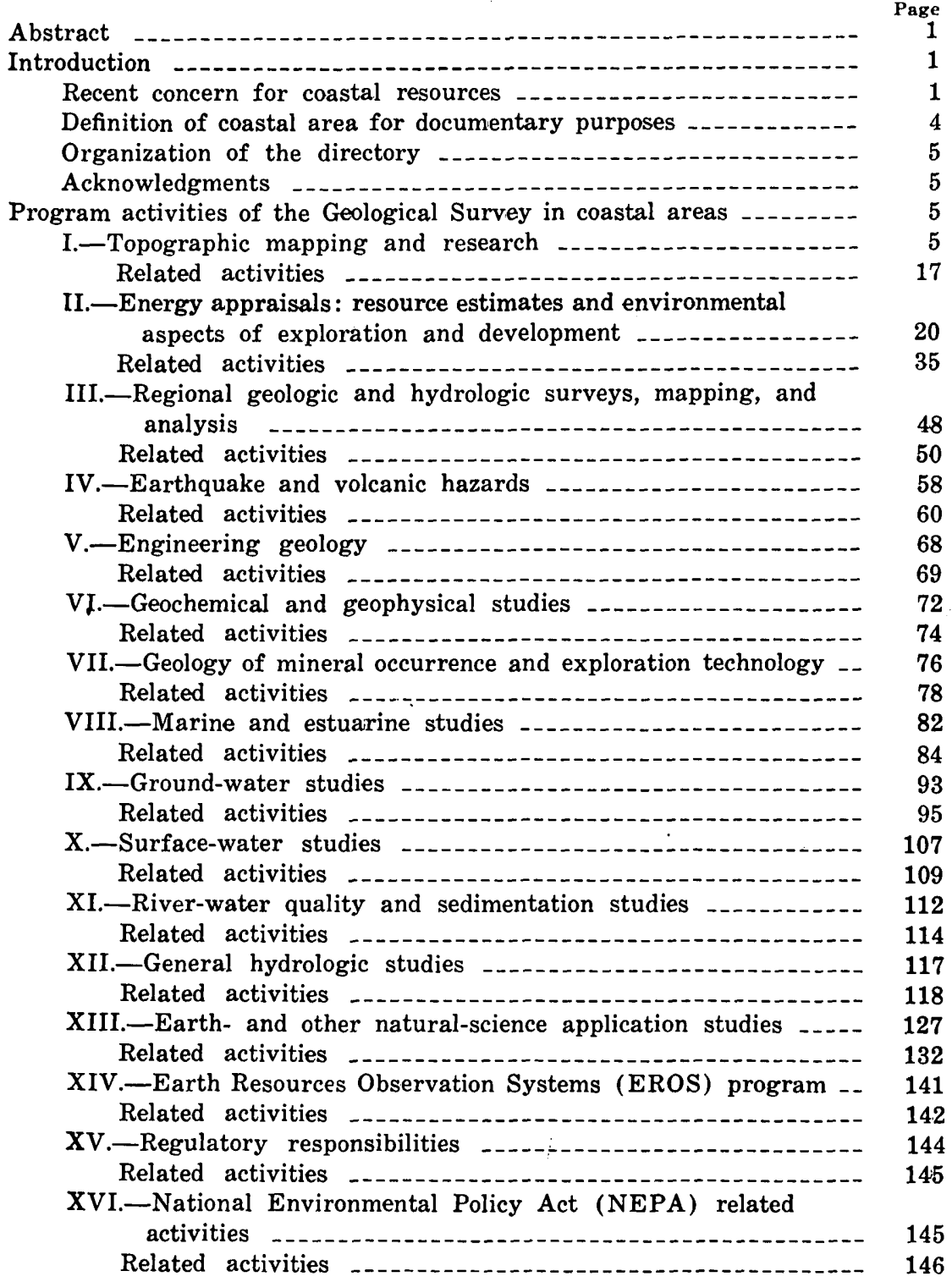


Indexes

Page

Principal contact code index

State index

References cited

\section{ILLUSTRATIONS}

Figure

1. Map showing coastal areas as designated in this directory

2-14. Maps showing status of-

2. Standard topographic mapping in the north Atlantic and eastern Great Lakes coastal regions

3. Standard topographic mapping in the western Great Lakes coastal region

4. Standard topographic mapping in the south Atlantic and Gulf coastal regions .........-

5. Standard topographic mapping in the Pacific coastal region -........-.

6. Standard topographic mapping in the Alaska

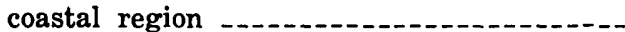

7. Standard topographic mapping in Hawaii ...--

8. Orthophotoquads of the north Atlantic and eastern Great Lakes coastal regions .....-

9. Orthophotoquads of the western Great Lakes coastal region

10. Orthophotoquads of the south Atlantic and

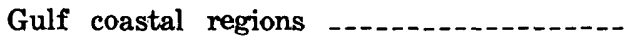

11. Orthophotoquads of the Pacific coastal region

12. The 1:250,000-scale topographic mapping -.--

13. National intermediate-scale topographic mapping

14. Land-use/land-cover map production

\section{TABLES}

TABLE 1. Major topographic map series of the U.S. Geological Survey

2. Scales of geologic maps commonly produced by the U.S. Geological Survey 


\title{
DIRECTORY TO U.S. GEOLOGICAL SURVEY PROGRAM ACTIVITIES IN COASTAL AREAS 1974-76
}

\author{
Philip A. Marcus, Editor
}

\begin{abstract}
This report describes 16 U.S. Geological Survey program activities in coastal areas of the United States and its territories during 1974-76 and lists the products of each project in the programs. It provides access to the Earthscience and other natural-science investigations in which the Geological Survey is currently engaged and which are capable of supporting coastal zone planning activities. Responsible individuals who can provide further assistance concerning project activities are listed. The text is organized by subject, and an index is provided for direct reference of projects on a State or territorial basis.
\end{abstract}

\section{INTRODUCTION}

The Geological Survey, a bureau of the U.S. Department of the Interior, performs research directed at increasing the understanding of the Earth's natural processes, history, and physical resources, including fuels, minerals, land, and water. The objective of Geological Survey research is to provide better information about resources which will enable more informed decisions to be made concerning their use and conservation. The purpose of this report is to provide the public with information on the activities of the Geological Survey in coastal areas of the United States and its territories during 1974-76.

This report is aimed at a broad audience, including Federal, State, and local officials, private interests, the scientific community, and the public, who are engaged in activities related to the use of coastal resources.

\section{RECENT CONCERN FOR COASTAL RESOURCES}

The use of coastal areas has recently emerged as a matter of high public concern for several reasons. Certain coastal ecosystems such as beaches, wetlands, and estuaries have been found to 
be quite susceptible to alteration and damage as a result of man's activities. A high value has been placed on many coastal areas because of their pristine biological nature, their ability to support the juvenile stages of many valuable fish species, and the preference of the public to use shorelands and beaches for recreation activities, among others.

Many coastal areas are suitable for industrial purposes also. In some cases, their proximity to lands with energy, mineral or other development potential, and ready access to markets and transportation facilities, coupled with an already large population and industrial base, have made them subject to multiple demands for use of a limited area. Moreover, many of these demands on coastal areas are incompatible with each other or are capable of seriously affecting the resource base and future utility to man of the coastal zone.

Two recent Congressional publications have documented present and anticipated multiple demands on the coastal zone (U.S. Senate Committee on Commerce, 1975a, b). Rapid population growth with its attendant requirements for housing and services represents a prime demand on coastal lands. Industries, particularly those requiring large amounts of water, have long favored coastal sites. The electric power industry, which is the largest user of cooling water, has already sited and is planning to site many large powerplants, both fossil and nuclear fueled, in coastal areas adjoining both the oceans and the Great Lakes. Other energyrelated facilities which prefer or require coastal sites include deepwater ports, undersea pipeline routings and their landfalls, refineries, liquid natural gas (LNG) storage and regasification facilities, and synfuels production facilities.

Recent new demands on the use of coastal areas have arisen from the decision by the Department of the Interior to accelerate the leasing schedule for Federal energy lands on the Outer Continental Shelf (OCS). The areas subject to leasing include those offshore of the East, Gulf, and Pacific Coast States and Alaska. All of these regions, with the exception of the gulf and parts of southern California, are considered "frontier" areas in that they have not yet experienced offshore oil and gas development.

Large uncertainties presently exist as to the occurrence, location, and the amount of commercially recoverable hydrocarbons on the OCS and the extent of the impacts-either positive or negative-which may befall States and localities which will provide support for OCS energy development activities. The uncertainties concerning the amounts of developable hydrocarbons present on 
the OCS will begin to be resolved as exploratory drilling is completed on those tracts leased. The net social, economic, and environmental impacts of OCS development may be addressed both by inquiries into the real effects that such development incurs and by measures to mitigate those short or long-term negative impacts which might occur.

These issues concerning the multiple use and guidance of development in the coastal zone are being addressed at both the Federal and State levels. The Coastal Zone Management Act of 1972 provides Federal support for eligible States to develop and implement comprehensive management plans for coastal resources. Eligible States are those bordering the Atlantic and Pacific Oceans, the Gulf of Mexico, and the Great Lakes and U.S. territories. Partial Federal support has been authorized for States whose management processes meet certain requirements. Bills have been passed in Congress to create funds for loans or grants to States which experience the onshore impacts of OCS energy development.

The 1972 Federal legislation provides administrative grants to eligible States to develop a number of planning and management functions. These include creating methods and procedures for determining permissible land and water uses, designating areas of particular concern, developing guidelines on the priority of uses in the coastal zone, and providing for the consideration of the national interest involved in the siting of facilities whose significance is more than local in nature.

The ability of the States to successfully develop the above methods and procedures will be determined in part by the adequacy of the earth- and natural-science information available to them. The information compiled, analyzed, and made available by the Geological Survey will be useful to the coastal States in their efforts to implement coastal zone management programs. Information is currently being provided by the Geological Survey for: (1) energy and mineral resource appraisals; (2) supervision of oil, gas, and mineral lease operations on Federal lands; (3) environmental assessment of proposed development; (4) the production of accurate maps on a variety of themes; (5) studies of water quality and quantity; and (6) applied earth- and other natural-science studies into issues in land and water use, among others.

As a directory to Geological Survey activities in coastal areas for the fiscal years of 1975 and 1976, (July 1974 to October 1976), this report presents an overview of areas of Geological 
Survey investigation and a description of current research. Bibliographies and references to principal contacts who can provide inquirers with more detailed information concerning project status, methods, and results are included.

Other printed sources of information on Geological Survey activities include Geological Survey Research, which summarizes the significant results of each year's investigations, New Publications of the Geological Survey, published monthly, and Publications of the Geological Survey, which contains all the new publications that have appeared in a given year.

This report will provide planners and decisionmakers access to earth-science and other natural-resources information that can serve as a basis for the resolution of issues associated with coastal resource management and use.

\section{DEFINITION OF COASTAL AREA FOR DOCUMENTARY PURPOSES}

The Coastal Zone Management Act of 1972 leaves the precise designation of the landward coastal zone boundary to State discretion but provides the following guidance for the landward boundary: "The coastal zone must include within it those lands which have any existing, projected or potential uses which have direct and significant impact upon the coastal water . . " (U.S. Dept. of Commerce, 1975). In 1976 many States are still in the process of defining their coastal zone.

For this report, the inland margin of the coastal area is defined as the landward boundaries of the coastal counties, townships, or parishes within the States and territories eligible for grants under the Coastal Zone Management Act of 1972. Geological Survey activities occurring outside that boundary have been included if the activity deals with processes or issues which have a direct and significant impact upon coastal water. In some cases the inland boundary of coastal wetlands or tidal waters exceeds the above defined boundary. In such situations, the inland margin of the coastal area will be described by the landward border of those counties, townships, or parishes which contain coastal wetlands. A separate definition was created for Alaska, which is not organized by counties. The Alaskan coastal area is defined to consist of the lands contained in the first two 15-minute topographic maps inland from the shore. In this report, the seaward margin of the coastal area will be the boundary of the OCS. Figure 1 is a map of the coastal areas for which current Geological Survey research is here being documented. All Geological Survey investigations that might be relevant to coastal zone planning that occur within, or 
that are pertinent to the coastal areas as defined above, are included in the lists of project references.

\section{ORGANIZATION OF THE DIRECTORY}

This directory is divided into 16 chapters describing program activities which are representative of broad Geological Survey research activities in coastal areas. A brief description is made of the program activity investigation, the issues, research needs, and goals which the program activities address, a description of characteristic products resulting from the program activity, and potential applications of study results for planning and management purposes.

After each program activity description is a listing of all fiscal year 1975-76 projects in coastal areas for the subject activity. Each project description contains the following: a title, index reference number, geographic location, a principal contact code which is keyed to an appendix of addresses where further information on the project and its products may be obtained, a statement on study objectives which describes the goals and approach of the project, and a bibliographic listing of project products published in fiscal years 1975 and 1976. The order of the project descriptions within a program activity is first those projects which have a national scope, then projects with a multi-State scope, and finally on a State by State basis.

An index lists all the project numbers on a State by State basis, so that direct reference may be made to the projects of interest.

\section{ACKNOWLEDGMENTS}

The text of this bulletin was compiled by the following individuals, whose efforts are greatly appreciated: Mark A. Boster, Wing L. Gee, Eugene R. Hampton, John L. Place, Edward J. Pluhowski, Stephen F. Pousardien, Michael O. Steed, and Paul G. Teleki.

\section{PROGRAM ACTIVITIES OF THE GEOLOGICAL SURVEY IN COASTAL AREAS I.-TOPOGRAPHIC MAPPING AND RESEARCH}

The Geological Survey publishes a number of standard topographic map series as well as several special maps of the United States and its territories. These maps are designed for general use and show the shape of the land and its drainage patterns, transportation and communications networks, other cultural developments, and timber coverage. Table 1 describes the major series of national topographic maps. 


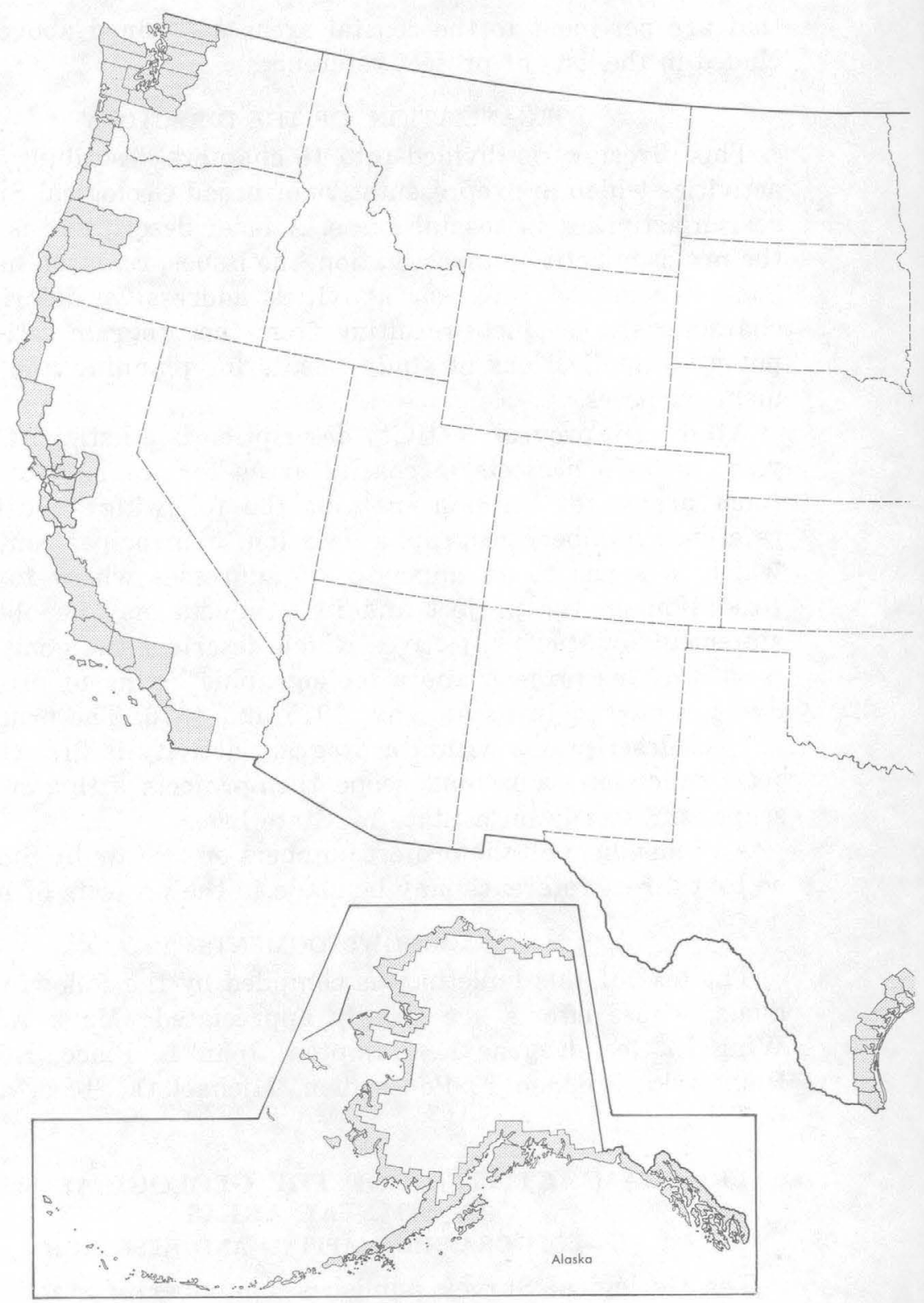

Figure 1.-Map showing coastal areas as designated in this directory.

Review of the 1:24,000-scale maps in the coastal zone is underway to determine which ones require revision. Photoinspection, the most common procedure used, consists of comparing the exist- 


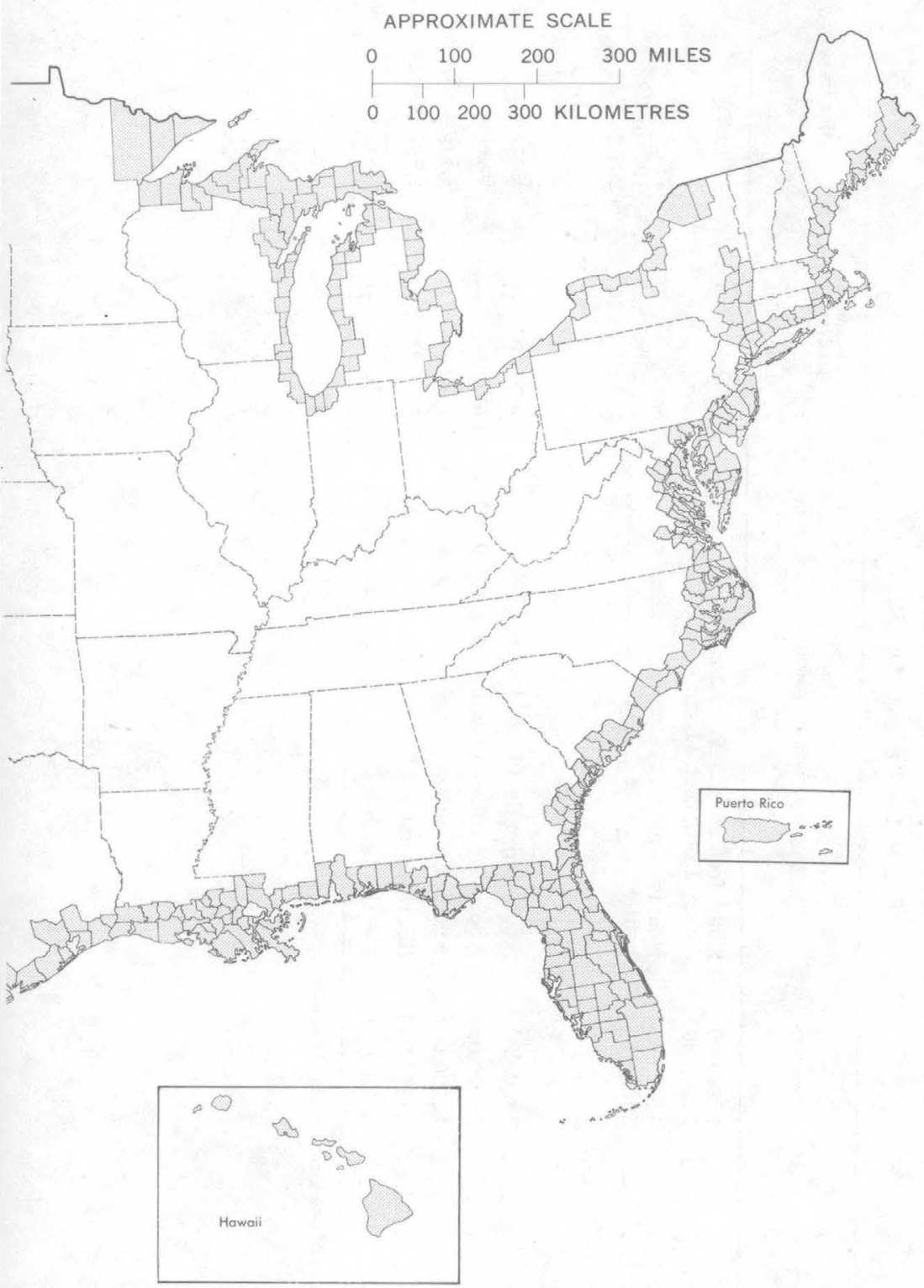

ing map with recent aerial photography. If sufficient changes are noted to warrant revision, the basic map is revised by using the same aerial photography. Changes are not usually field checked 
TABLE 1.-Topographic Maps.

\begin{tabular}{|c|c|c|c|c|}
\hline Series & Scale & 1 inch represents: & $\begin{array}{c}\text { Standard } \\
\text { quadrangle } \\
\text { size } \\
\text { (latitude- } \\
\text { longitude) }\end{array}$ & $\begin{array}{l}\text { Quadrangle } \\
\text { area } \\
\text { square } \\
\text { miles) }\end{array}$ \\
\hline $\begin{array}{l}71 / 2-\text { minute } \\
71 / 2 \text {-minute, Puerto Rico }--\end{array}$ & $\begin{array}{l}1: 24,000 \\
1: 20,000\end{array}$ & $\begin{array}{l}2,000 \text { feet } \\
\text { About } 1,667 \text { feet }(1 \mathrm{~cm} \text { equals } 200 \mathrm{~m})\end{array}$ & $71 / 2 \times 71 / 2 \mathrm{~min}_{--}$ & 49 to 70 \\
\hline $\begin{array}{l}\text { 15-minute } \\
\text { Alaska, } 1: 63,360\end{array}$ & $\begin{array}{l}1: 62,500 \\
1: 63,360\end{array}$ & $\begin{array}{l}\text { Nearly } 1 \text { mile } \\
1 \text { mile }\end{array}$ & $\begin{array}{l}71 / 2 \times 71 / 2 \min _{--} \\
15 \times 15 \text { min }-- \\
15 \times 20 \text { to } 36 \\
\quad \text { min }\end{array}$ & $\begin{array}{l}71 \\
197 \text { to } 282 \\
207 \text { to } 281\end{array}$ \\
\hline \multicolumn{5}{|l|}{ Intermediate scales: } \\
\hline County maps ------- & $\begin{array}{l}1: 50,000 \\
1: 100,000\end{array}$ & $\begin{array}{l}\text { About } 0.8 \text { mile }(1 \mathrm{~cm} \text { equals } 500 \mathrm{~m}) \\
\text { About } 1.6 \text { miles }(1 \mathrm{~cm} \text { equals } 1,000 \mathrm{~m})\end{array}$ & 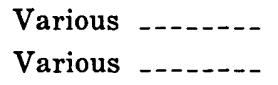 & $\begin{array}{l}\text { Various } \\
\text { Various }\end{array}$ \\
\hline Quadrangle maps --.- & $1: 100,000$ & About 1.6 miles $(1 \mathrm{~cm}$ equals $1,000 \mathrm{~m})$ & $30 \min \times 1^{\circ} \ldots$ & 1,590 to 2,100 \\
\hline U.S. $1: 250,000$ & $1: 250,000$ & Nearly 4 miles & ${ }^{1} 1^{\circ} \times 2^{\circ} \ldots$ & 4,580 to 8,669 \\
\hline U.S. $1: 1,000,000$ & $1: 1,000,000$ & Nearly 16 miles & ${ }^{1} 4^{\circ} \times 6^{\circ}$ & 73,734 to 102,759 \\
\hline
\end{tabular}

${ }^{1}$ Maps of Alaska and Hawaii vary from these standards. 
and are printed in purple for easy identification. If the original map is very old or of questionable accuracy, more complete methods of revision (up to and including complete remapping) are sometimes used. Once updating is completed, a 5-year photoinspection/revision cycle is established.

Many of the coastal areas not covered by 7.5-minute maps are covered by less current 15-minute 1:62,500-scale topographic maps in the conterminous United States and 15-minute 1:63,360scale maps in Alaska. Most of the 15 minute maps are more than 20 years old.

Figures 2-5 show the availability of standard quadrangle maps and the areas where new maps and revisions are in progress. The 7.5-minute series is emphasized on these graphics. The availability of the 15-minute series is shown only where the 7.5-minute series is not available, that is, only the 7.5-minute series is shown for areas where both series are available. Individual State topographic indexes should be consulted for more complete information on the availability of these two series. Figures 6 and 7 show the availability of the standard 1:63,360-scale topographic quadrangle mapping of Alaska and the 1:24,000-scale mapping of Hawaii, respectively.

Another 1:24,000-scale product available for many parts of the coastal zone is the orthophotoquad. An orthophotoquad is prepared from aerial photography in the standard 7.5-minute quadrangle format. The image is processed to eliminate distortion and to display each feature in its correct geographic position. These versatile products are used as interim maps for unmapped areas and as companions to published maps. Orthophotoquads often show the subtle changes in vegetative cover that may identify the margins of wetlands and certain other vegetative communities. Specific land-use patterns can also be identified and delineated with a great degree of accuracy on this product.

The availability of orthophotoquads is depicted in figures 8-11. Not all orthophotoquads are published. For those quadrangles not published, photographic and/or ozalid copy is available. The National Cartographic Information Center, described later, can provide more specific information on the availability of orthophotoquads.

The National Park map series provides coverage for selected National Parks, monuments, and historic sites. Many of these maps are available with shaded relief for a three-dimensional effect. National Park maps in the coastal zone that are published or are in progress include: 


\section{EXPLANATION}

71/2-minute mapping available

15-minute mapping available

Work in progress

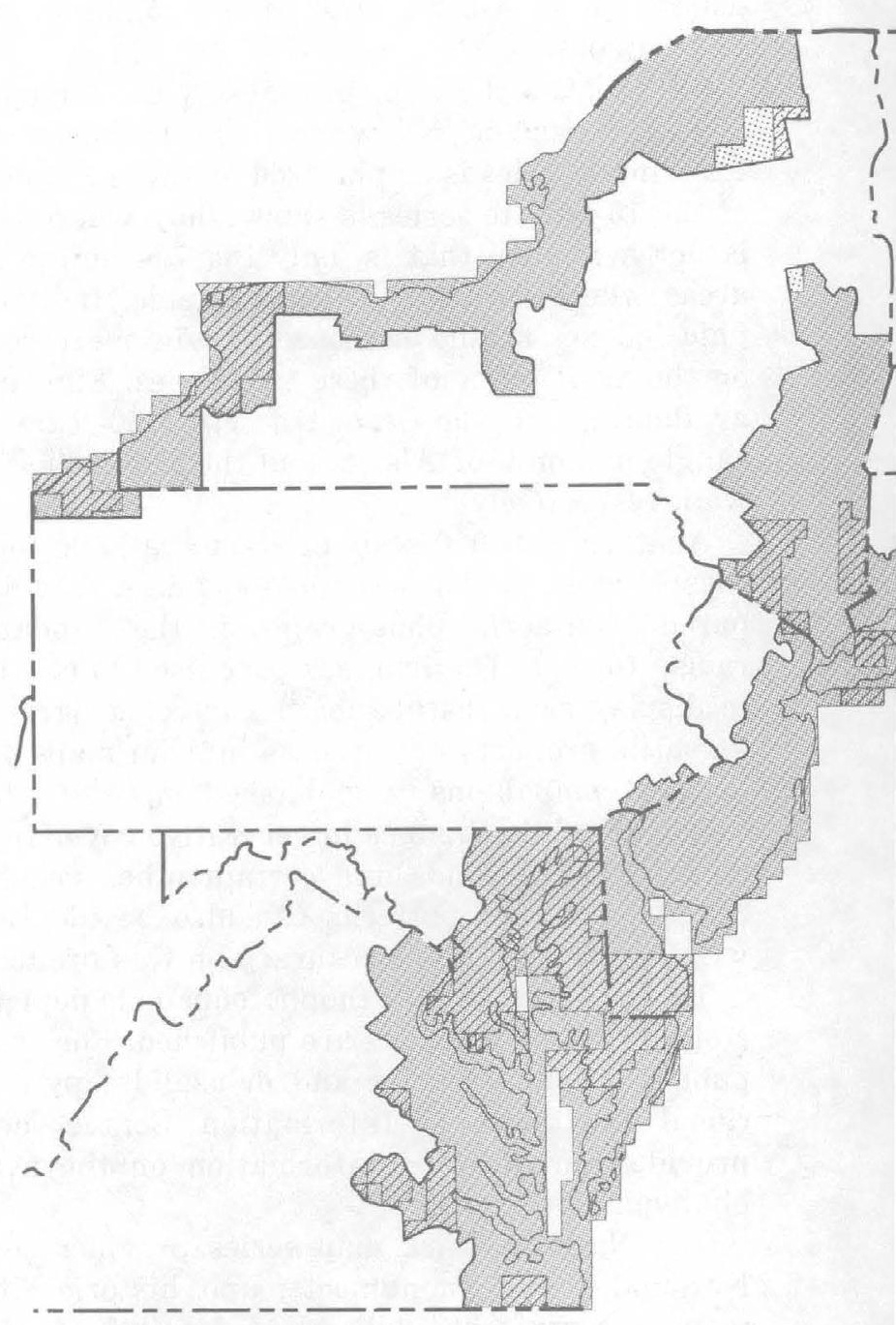

Figure 2.-Status of standard topographic mapping in the north Atlantic and eastern Great Lakes coastal regions. 


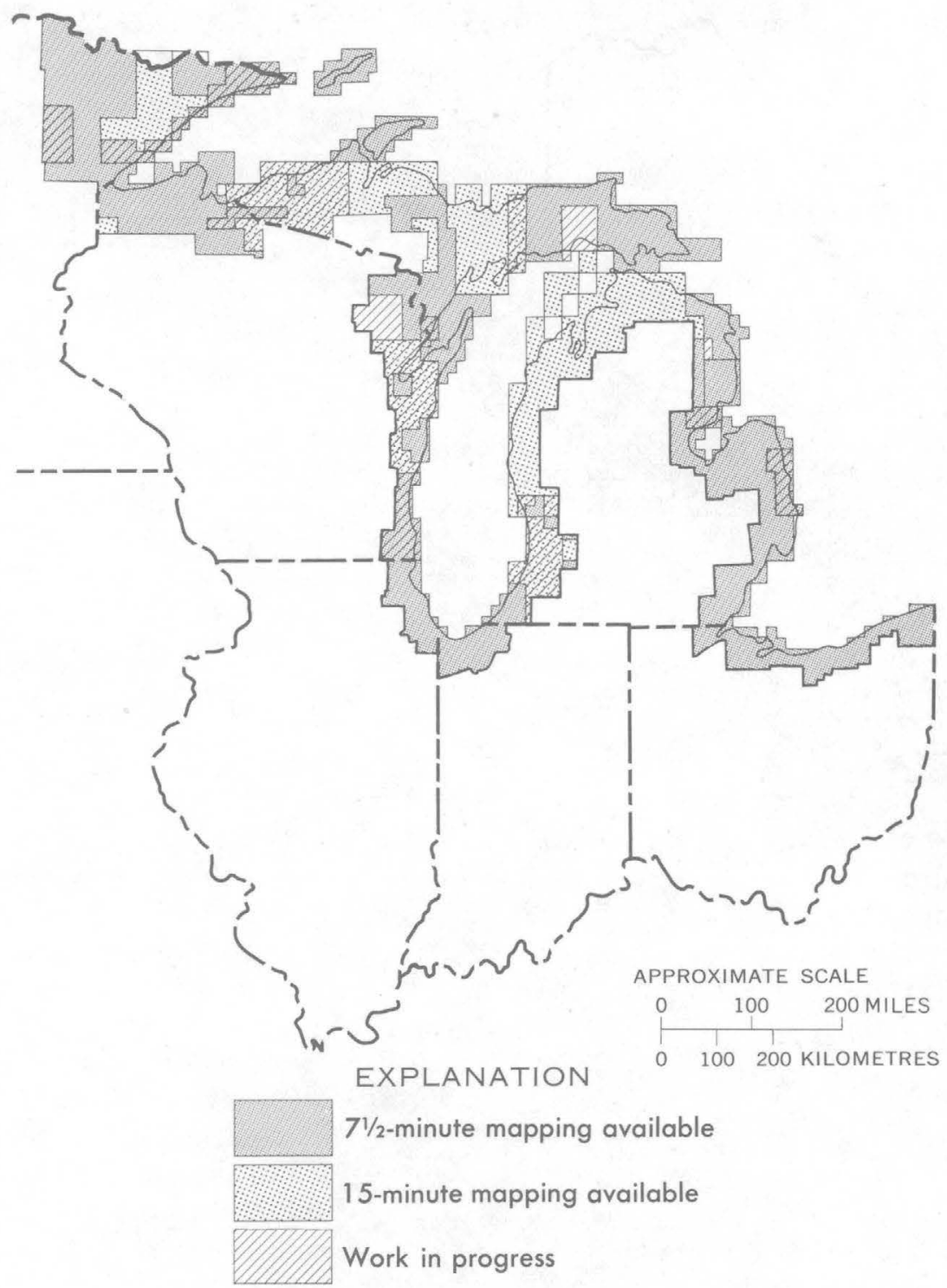

Figure 3.-Status of standard topographic mapping in the western Great Lakes coastal region.

Acadia National Park, Maine

Isle Royale National Park, Michigan

Olympic National Park, Washington

Point Reyes National Seashore, California 
Nationwide coverage, including the complete coastal zone, is provided by the $1: 250,000$-scale ( 1 inch $=\sim 4$ miles) topographic map series. Figure 12 shows the maps in this series that are currently being revised.

Other series available include the intermediate 1:50,000- and $1: 100,000$-scale topographic maps, $1: 500,000$ - and $1: 1,000,000$ scale State maps, and the 1:1,000,000-scale International Map of the World (IMW) sheets. The recently introduced intermediatescale maps are published in two scales and formats. The quadrangle format, 30 minutes in latitude by 1 degree in longitude, is published at the 1:100,000 scale. Other maps are prepared in a county format, primarily at the $1: 50,000$ scale but at the $1: 100,000$ scale for larger counties. Intermediate-scale maps published and in progress are depicted in figure 13. The State maps are available in three editions: base or planimetric, topographic, and shaded relief. Shaded relief maps are not generally available for States such as Florida where the terrain is flat. The IMW series are topographic quadrangles that use color tints in conjunction with the contour lines to aid in distinguishing elevations. Information on topography and bathymetry are both shown in metric units.

The Geological Survey and the National Ocean Survey (NOS) have entered into an agreement to combine topographic and hydrographic information on coastal maps and thus form a new product, the "topo-bathy" map. These maps are standard topographic maps, orthophotomaps, and orthophotoquads, together with as much bathymetry, including mean high water (MHW), mean low water (MLW), and other hydrographic data normally depicted on NOS products, as the published map scale permits. This product is designed to serve the map needs of land-use planners, physical scientists, conservationists, land surveyors, geologists, oceanographers, and others having an interest in management of the coastal zone, the wetlands, and the offshore environment. Two projects have been published to date. One is the Beauford, North Carolina-South Carolina 1:250,000-scale topo-bathy map, and the other is a group of three prototype 1:24,000-scale products, the orthophotoquad, the orthophotomap, and the topographic map, each with bathymetric data offshore. Other sheets in progress include five new intermediate-scale topo-bathy maps at the $1: 100,000$ scale along the Georgia coast.

In addition to the standard topographic maps, a number of special products and byproduct maps are also available. These include aerial photography, Landsat imagery and products, slope 


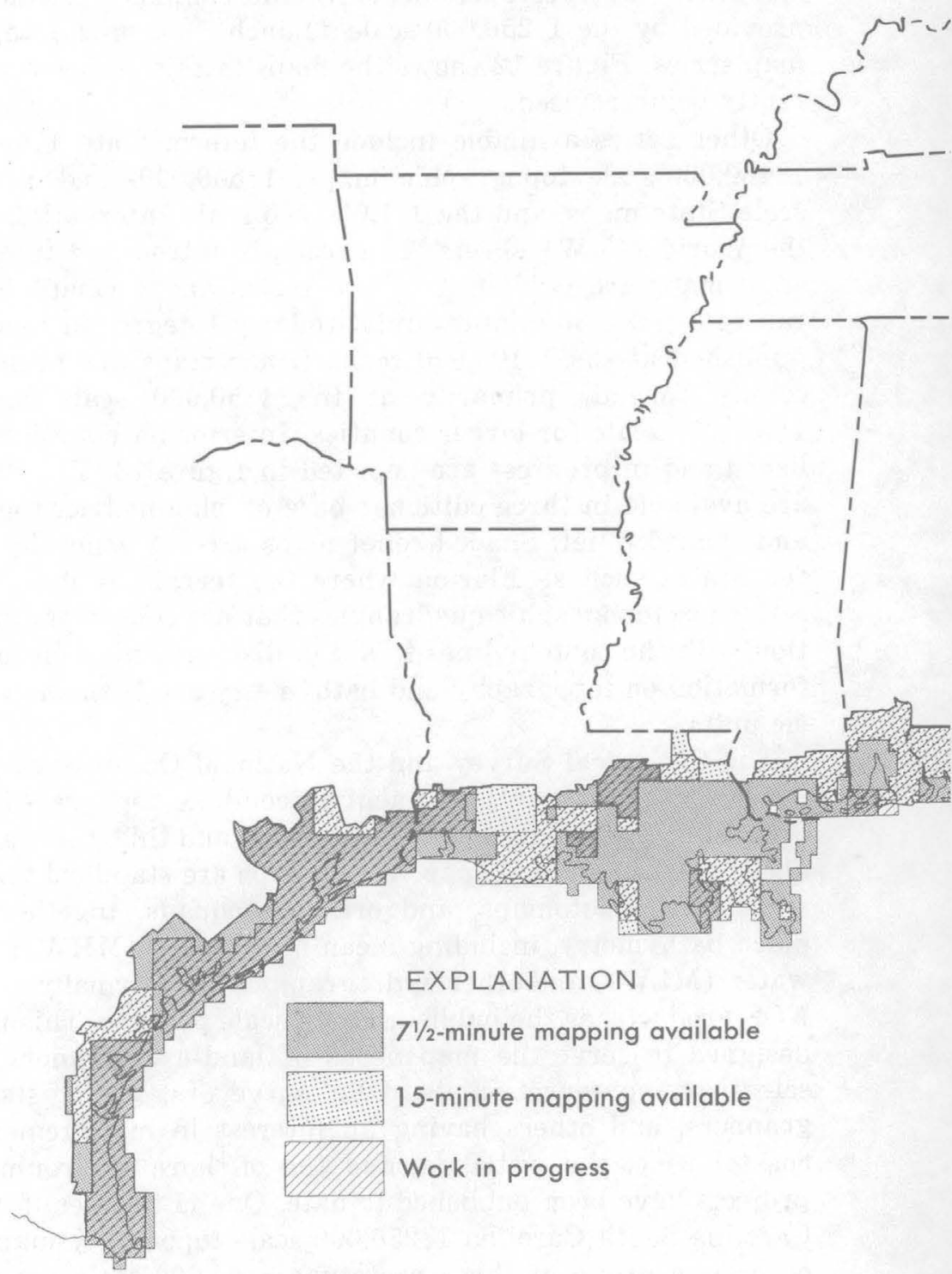

Figure 4.-Status of standard topographic mapping in the south Atlantic and Gulf coastal regions.

maps, and large-scale maps (scales $1: 1,200$ to $1: 6,000$ ) ; aerial photographic coverage for areas of 7.5-minute topographic and orthophoto quadrangle maps; digital data tapes containing the 


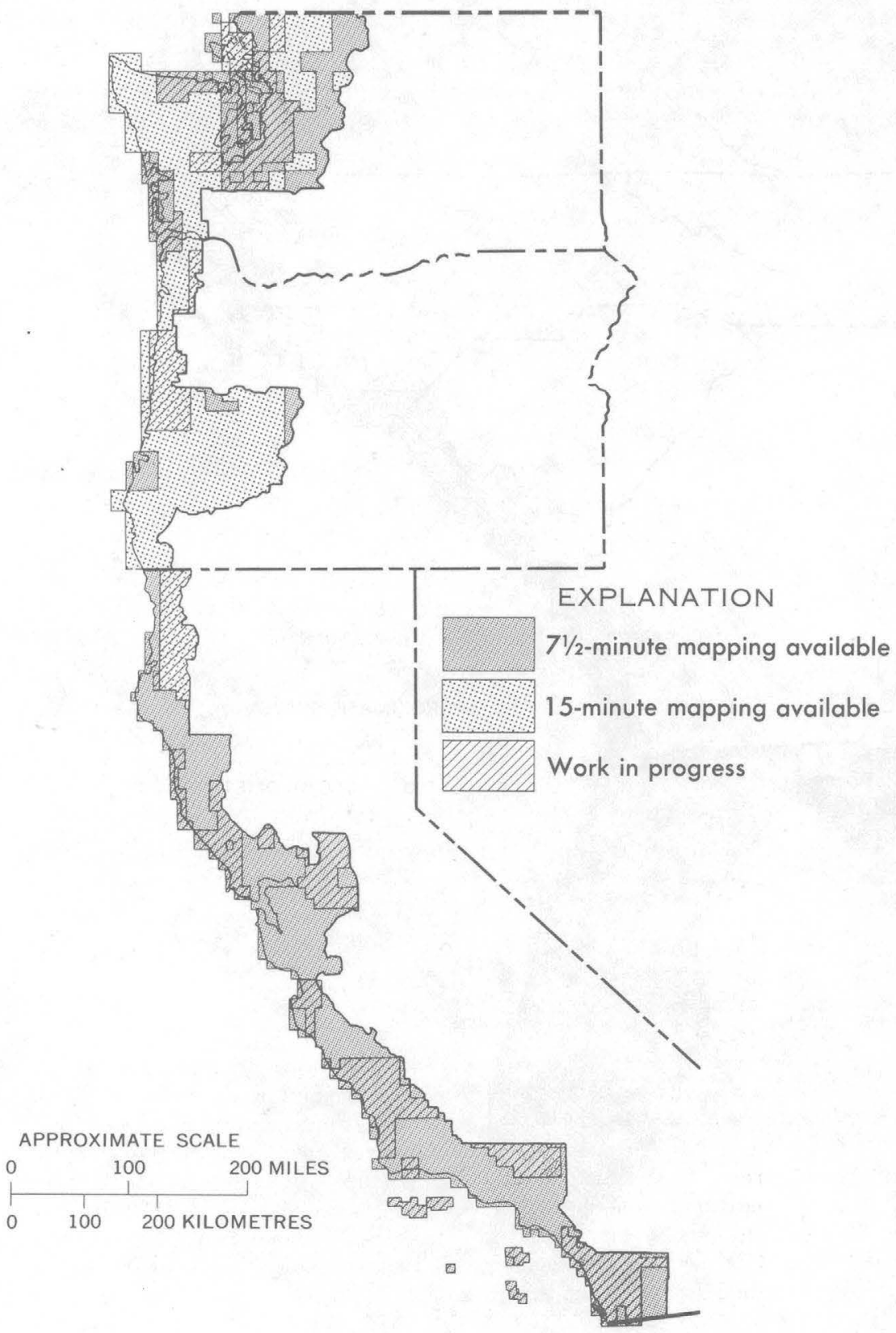

Figure 5.- Status of standard topographic mapping in the Pacific coastal region. 
Indexes showing published topographic maps are available free of charge for each State and for Puerto Rico, the Virgin Islands, Guam, and American Samoa. These indexes contain lists of special maps, addresses of local map reference libraries, local map dealers, and Federal map distribution centers. Indexes are not yet available for the intermediate-scale county and quadrangle maps. Indexes can be ordered from the Branch of Distribution, U.S. Geological Survey, 1200 South Eads Street, Arlington, VA 22202, for States east of the Mississippi River and also for Minnesota, Puerto Rico, and the Virgin Islands; and from the Branch of Distribution, U.S. Geological Survey, Federal Center, Box 25286, Denver, CO 80225, for States west of the Mississippi River and also for American Samoa and Guam.

The National Cartographic Information Center (NCIC) provides a central location for obtaining information on the cartographic data available for the Nation. The NCIC collects, organizes, and distributes, without charge, information about the maps, charts, aerial photography, survey monuments, and related cartographic data available from Federal and State government agencies and private sources. Information can be obtained by writing to the National Cartographic Information Center, 507 National Center, Reston, VA 22092. Information can also be obtained by telephoning (703) 860-6045 (FTS 928-6045) from 8 a.m. to 4 p.m. Monday through Friday. A telephone answering and recording service is provided at all other times.

\section{RELATED ACTIVITIES}

Title: Coastal Mapping Handbook (I-1)

Status: Ongoing FY 76 .

Location: Coastal areas of the United States and its territories

Principal Contact: TD-1

Objective: To provide general information and guidance on mapping in coastal areas. The handbook provides information on mapping products and data sources as well as on sources of technical assistance. The handbook will assist planners and managers of coastal programs in determining their mapping requirements, selecting the best maps and charts for their particular needs, and communicating effectively with data-producing organizations. The handbook is a joint effort of the National Ocean Survey and Office of Coastal Zone Management of the National Oceanic and Atmospheric Administration and the Geological Survey.

Product:

Baxter, F. S., Ellis, M. Y., Fitzgerald, I. Y., and Stang, P. R., 1976, Coastal zone mapping handbook, 500 p., draft.

Title: Remote Sensing and Mapping of Coastal Wetlands (I-2)

Status: Ongoing FY 76 


\section{EXPLANATION}

71/2-minute mapping available

15-minute mapping available

Work in progress

APPROXIMATE SCALE
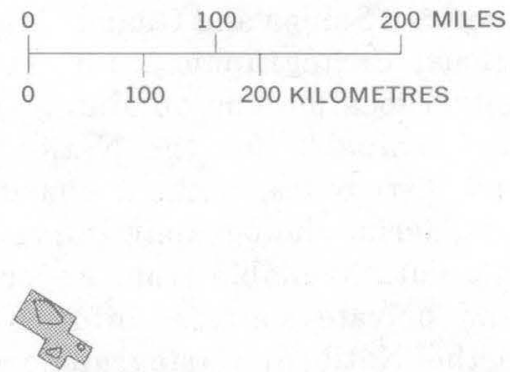

Figure 6.-Status of standard topographic mapping in the
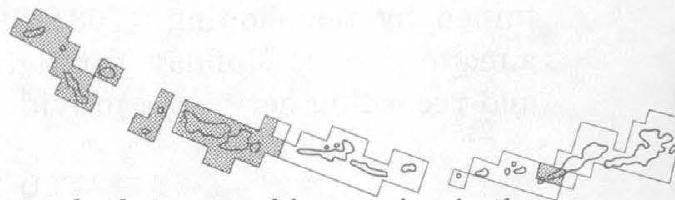
Alaska coastal region.

\section{Location: Sapelo Island, Georgia}

Principal Contact: TD-2

Objective: To investigate procedures for interpreting, delineating, and mapping coastal wetlands by using remote sensing and photogrammetric techniques. Orthophotoquads were prepared at the $1: 10,000$ scale with a format of 2.5 minutes of latitude and 3.75 minutes of longitude. Coastal wetland boundaries and species associations were interpreted from colorinfrared photographs and delineated on the orthophoto base. The study evaluates the accuracy, time, and cost for mapping coastal wetlands and the associated legal, engineering, and cartographic issues.

Products:

McEwen, R. B., Kosco, W. J., and Carter, Virginia, 1976, Coastal wetland mapping: Photogramm. Eng. and Remote Sensing, v. 42, no. 2, p. 221232.

U.S. Geological Survey, 1973, Coastal wetlands orthophotoquad, Doboy Sound 7.5-min quadrangle: 6 sheets, scale $1: 10,000$. 
EXPLANATION

71/2-minute mapping available

15-minute mapping available
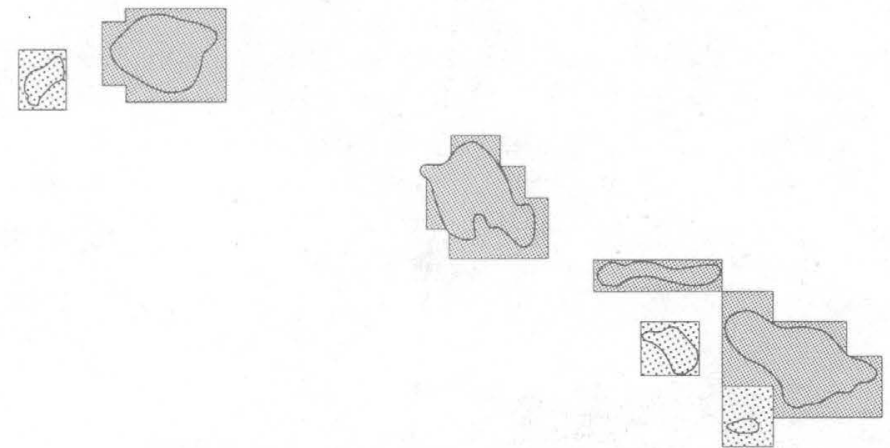

APPROXIMATE SCALE
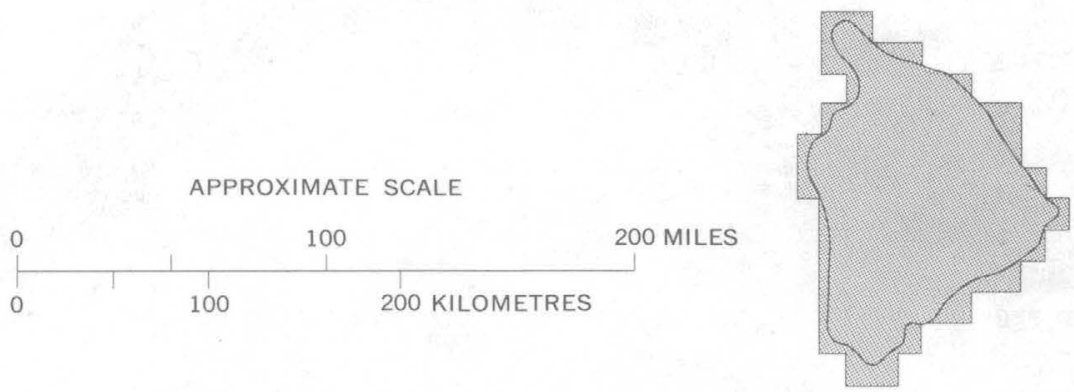

Figure 7.-Status of standard topographic mapping in Hawaii.

Title: Topographic Mapping and Research, Rocky Mountain Mapping Center (I-5)

Location: Alaska and Texas

Principal Contact: TD-1, TD-4

Title: Topographic Mapping and Research, Western Mapping Center (I-6) Location: California, Hawaii, Oregon, and Washington Principal Contact: TD-1, TD-5

II.-ENERGY APPRAISALS: RESOURCE ESTIMATES AND ENVIRONMENTAL ASPECTS OF EXPLORATION AND DEVELOPMENT

The Geological Survey is involved in qualitatively and quantitatively assessing the Nation's energy resources, evaluating the environments in which these resources may be found, and the impacts which may result from energy exploration and development. 
The energy resources which the Geological Survey is appraising are oil, gas, coal, oil shale, uranium, thorium, and geothermal. Energy-related activities are also discussed in several other sections in the text, particularly in "IV.-Earthquake and Volcanic Hazards," "V.-Engineering Geology," and "XIII.-Earth- and other Natural-science Application Studies."

The main objective of the Geological Survey's energy-resources studies is to provide information which will enable sound decisions to be made regarding resource allocation and environmental protection. The Geological Survey provides technical assistance to the Bureau of Land Management (BLM), which is the Interior agency responsible for leasing Federal lands. The Geological Survey assists in the selection of general areas subject to inclusion in a lease sale and is responsible for appraising the energy resources of an area after it has been proposed for mineral leas: ing and for establishing a fair market value on tracts to be leased.

Objectives of investigations relating to the oil and gas potential of Federal lands are: (1) to develop and apply technology capable of identifying and evaluating possible hydrocarbon source rocks; (2) to develop geophysical procedures for locating structural and stratigraphic traps likely to contain accumulations of oil and/or gas; and (3) to determine the recoverability of the oil and gas. Methods applied to meet these objectives are numerous and include studies on porosity and permeability of potential and commercial reservoirs, on anomalies identified by trace-element analysis, and borehole measurements of physical and chemical properties of the strata. Data obtained from these and conjunctive investigations are used to predict reservoir quality and areal extent of the resource.

Offshore oil and gas resource investigations focus on the assessment of potential oil and gas resources of the Outer Continental Shelf (OCS) lease areas. Substantial data collection is required prior to leasing offshore tracts. The Geological Survey acquires geologic data by conducting ship and airborne surveys or by purchasing proprietary data from industry. This information is subsequently coordinated with data obtained by other Government agencies for resource and environmental assessment purposes.

Objectives of these OCS oil and gas studies are: (1) to evaluate the regional oil and gas resources of the Continental Shelf, Slope, and Rise; (2) to determine local areas which have significant oil and gas potential and which may be included in additional OCS lease sales; and (3) to provide geological resource data and analysis to Federal and State Governments and the public. 
EXPLANATION

71/2-minute orthophotoquads available

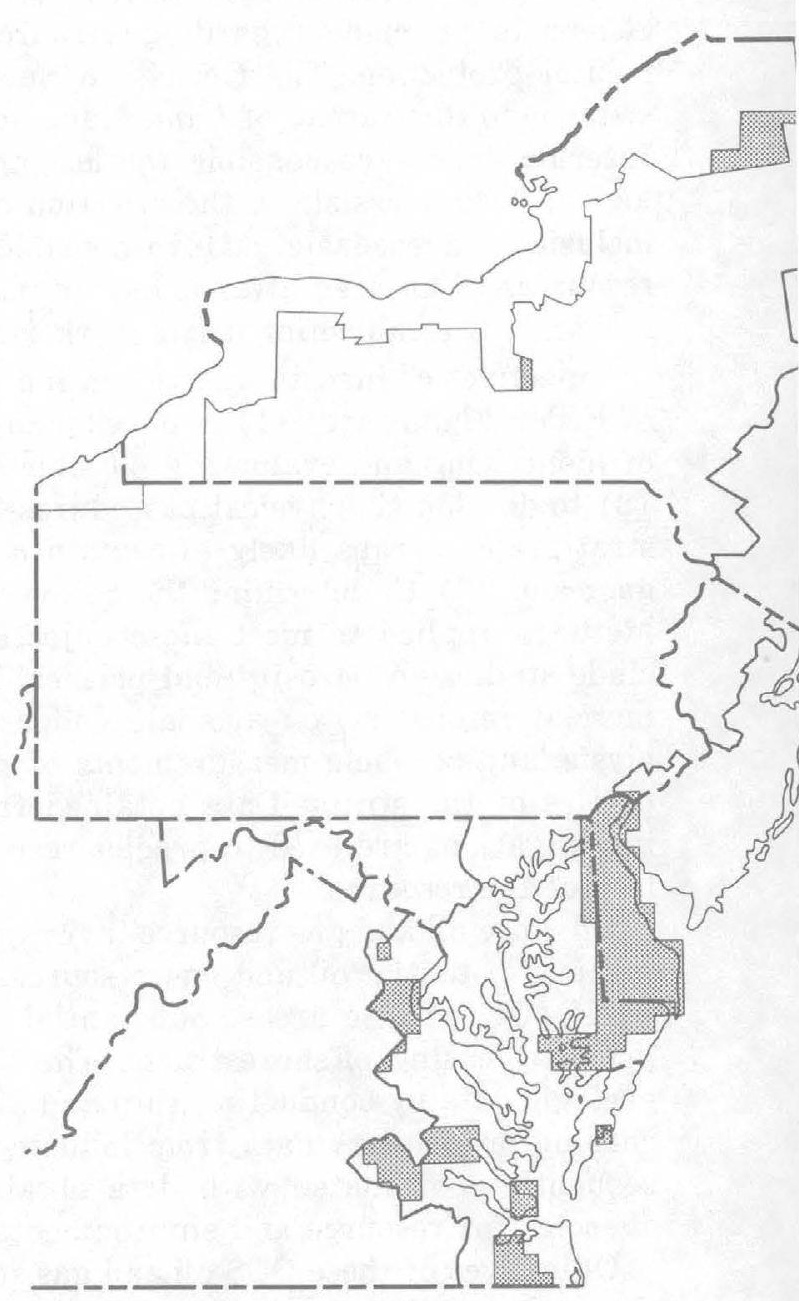

FIGURE 8.-Status of orthophotoquads in the north Atlantic and eastern Great Lakes coastal region. 


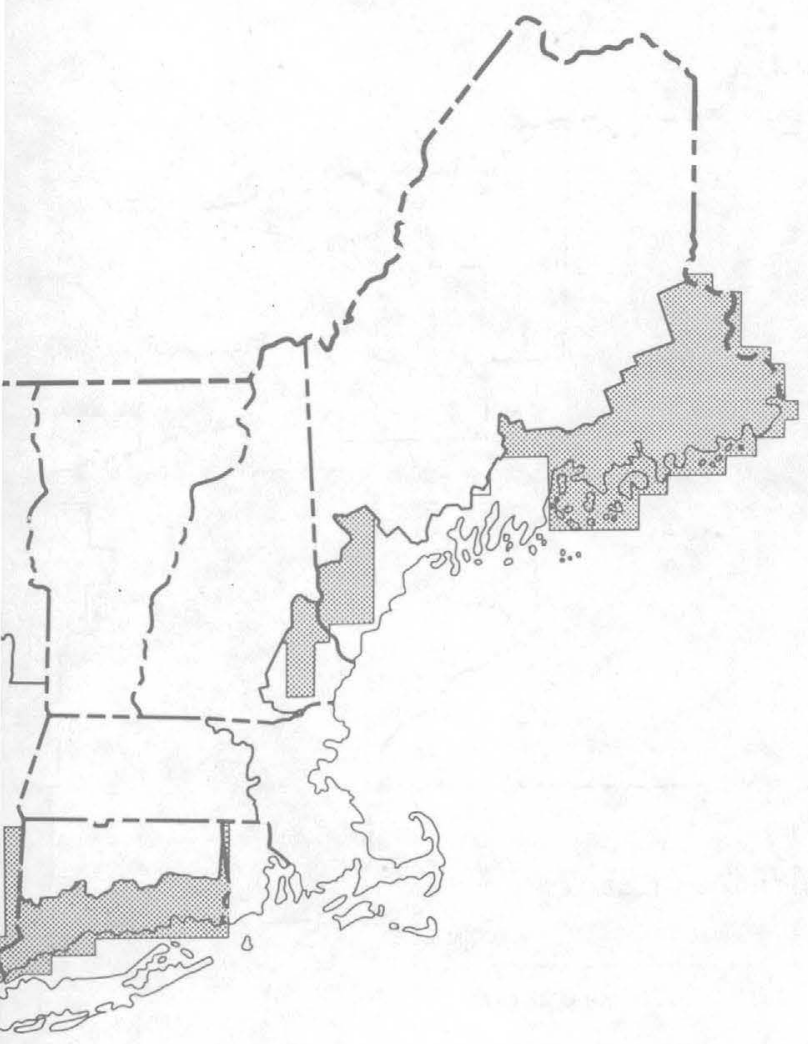

APPROXIMATE SCALE

$\left.\right|_{0} ^{0} \quad 1_{100} \frac{100}{200 \text { KILOMETRES }}$




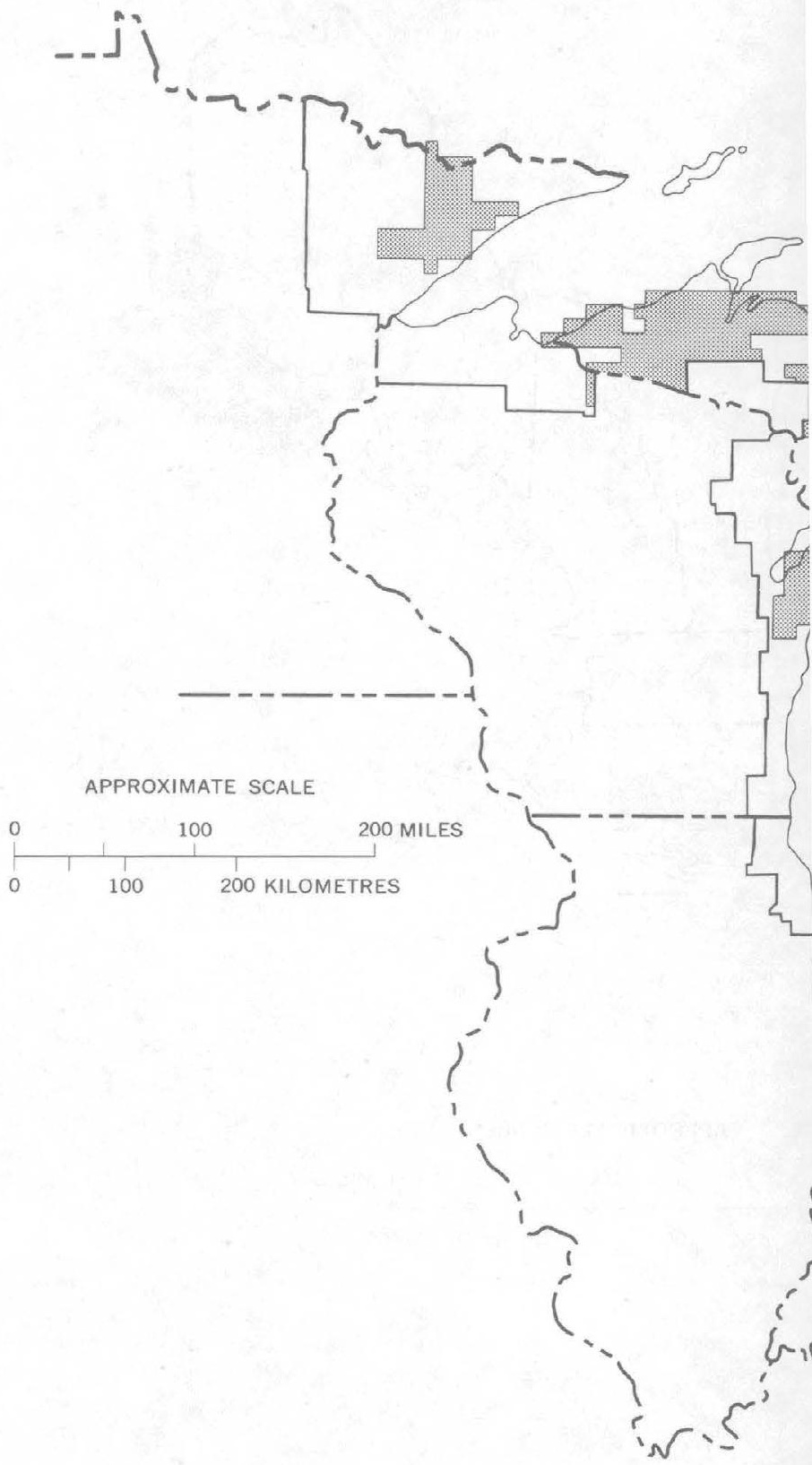

FIGURE 9.-Status of orthophotoquads in the western Great Lakes coastal region. 
EXPLANATION

71/2-minute orthophotoquads available

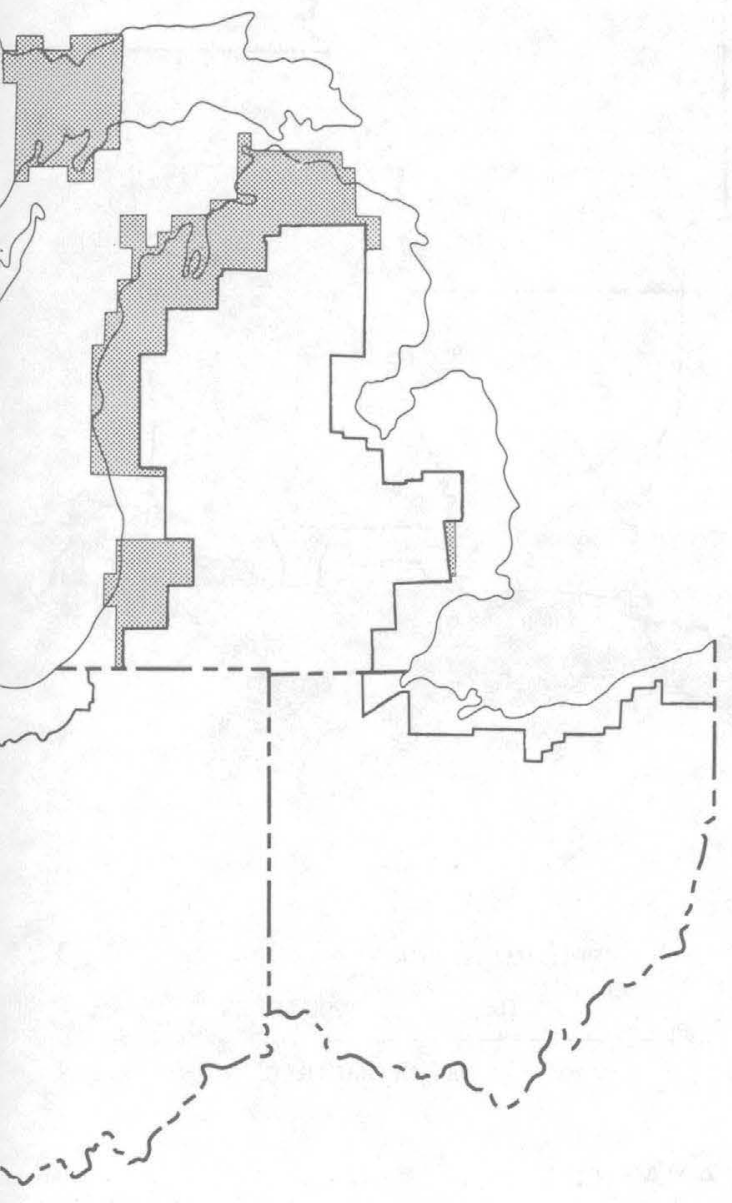




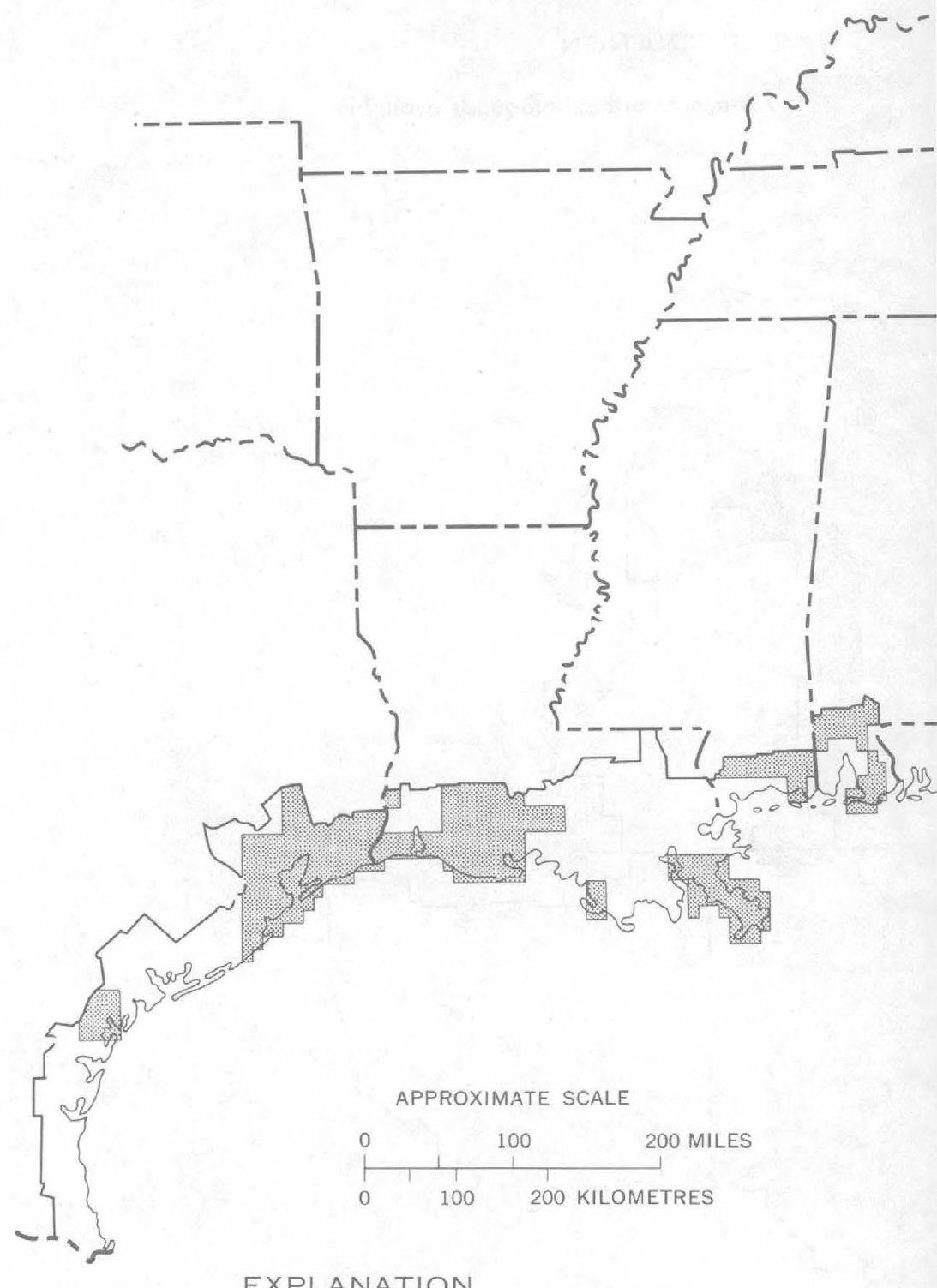

EXPLANATION

71/2-minute orthophotoquads available

Figure 10.-Status of orthophotoquads in the south Atlantic and Gulf coast regions. 


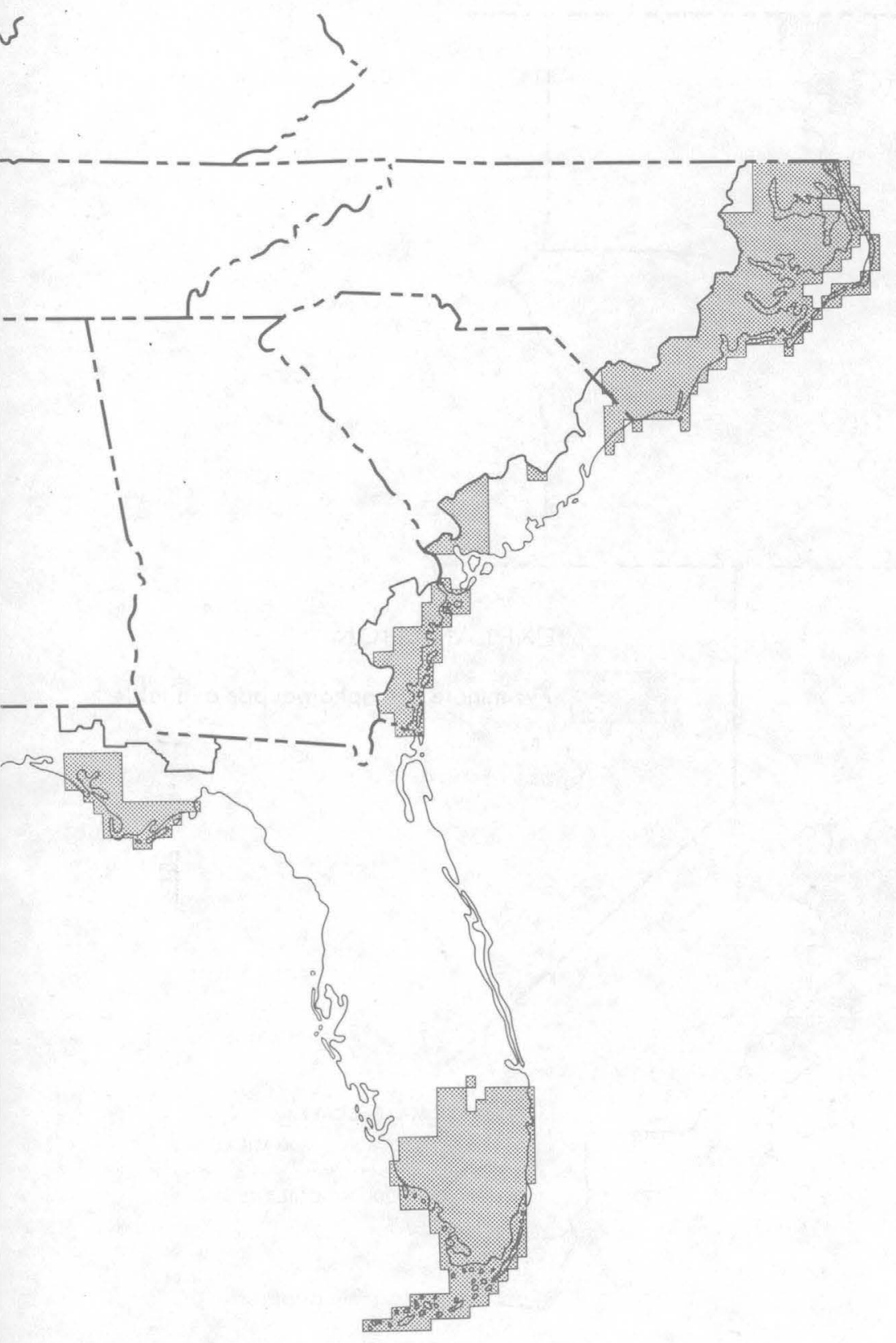




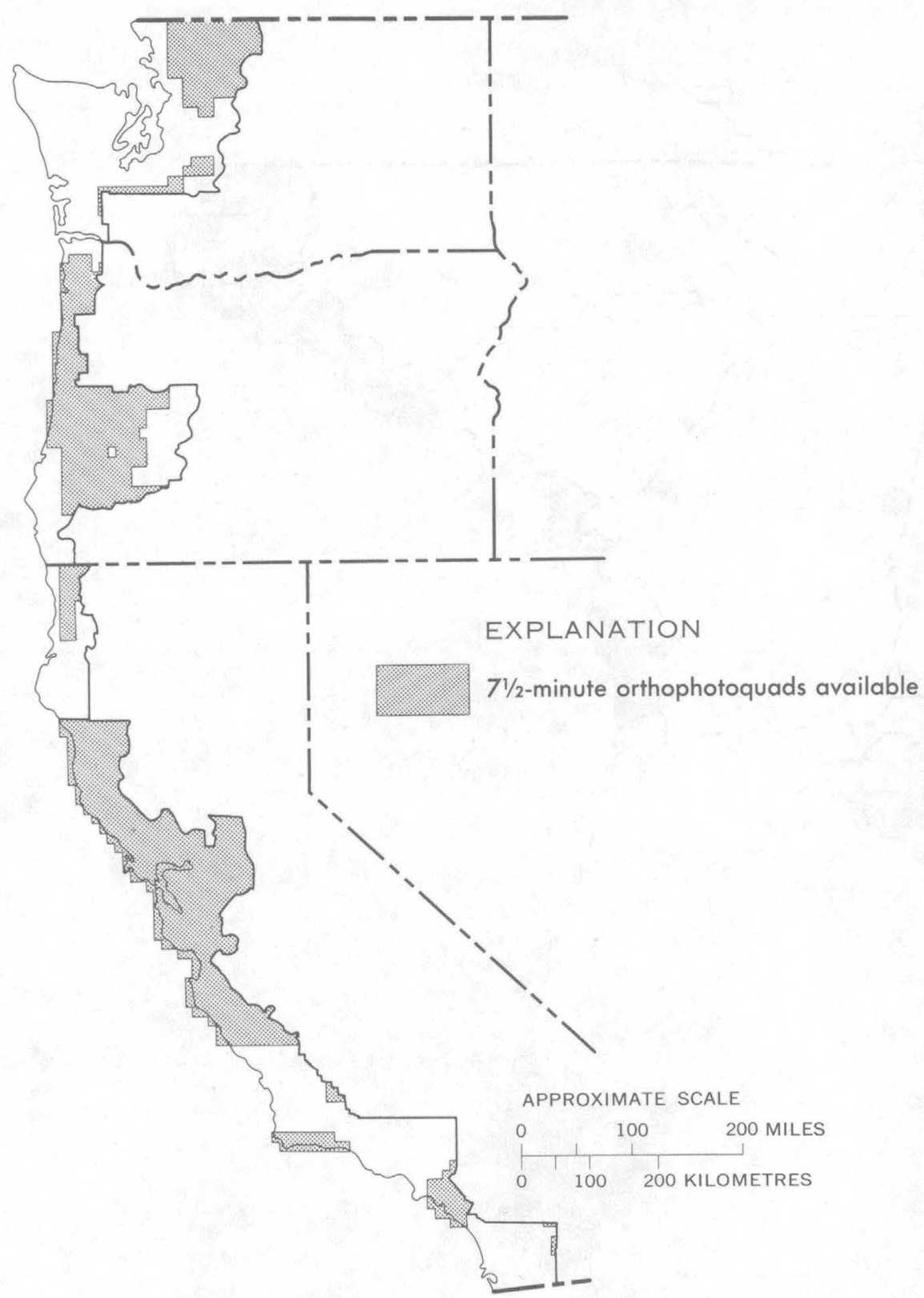

Figure 11.-Status of orthophotoquads in the Pacific coast region. 
The commonly used scientific approach in these "frontier" areas consists of delineation of sedimentary basins followed by the evaluation of the geologic conditions conducive to the accumulation of oil and gas in appreciable quantities, estimation of the area's potential volume of oil and gas, and the estimation of fair market value on a tract by tract basis. These activities have recently experienced considerable acceleration because of the Department of the Interior's accelerated OCS leasing schedule. Inhospitable environments, for example, that of Alaska, limit the necessary geophysical and environmental surveys to only a few months a year.

Geological Survey geologists, geophysicists, and petroleum engineers are continually conducting investigations on the occurrence of mineral deposits in the OCS by means of seismic and subsurface geologic mapping. This mapping provides the necessary information in evaluating tracts prior to leasing and in determining reserves of mineral deposits. Results of these investigations by Geological Survey personnel are primarily for internal support and are not published because of the confidential nature of the basic data, much of which is obtained from both private geophysical data collecting and oil companies.

The Geological Survey has received, and is currently receiving, information from deep stratigraphic tests drilled by industry on the OCS prior to leasing. These tests provide useful geological information which aids in making resource evaluations, as well as in the protection of the environment in the event of future resource development. Test holes are either underway or are planned in several OCS areas: Georges Bank, the Baltimore Canyon Trough, the Southeast Georgia Embayment and Blake Plateau, offshore from the Mississippi Delta and south Texas, the southern California Borderland, the Gulf of Alaska, and the Bering, Chukchi, and Beaufort Seas. Estimate ranges for recoverable oil and gas resources are developed on the basis of a comparison of the geologic history of the area to geologically similar areas with known oil and gas deposits. A detailed geophysical, geological, and engineering evaluation is conducted on a tract by tract basis prior to a lease sale in order to establish a fair market value for each tract. Each tract consists of a maximum of 5,760 acres (2,331 hectares). When a sale is held, companies or individuals may submit sealed bids for each tract offered. Bids which do not meet the minimum value established for a particular tract are subject to rejection. Geological Survey presale tract values are released on all tracts bid on after the sale has been held. Presale value for those tracts 


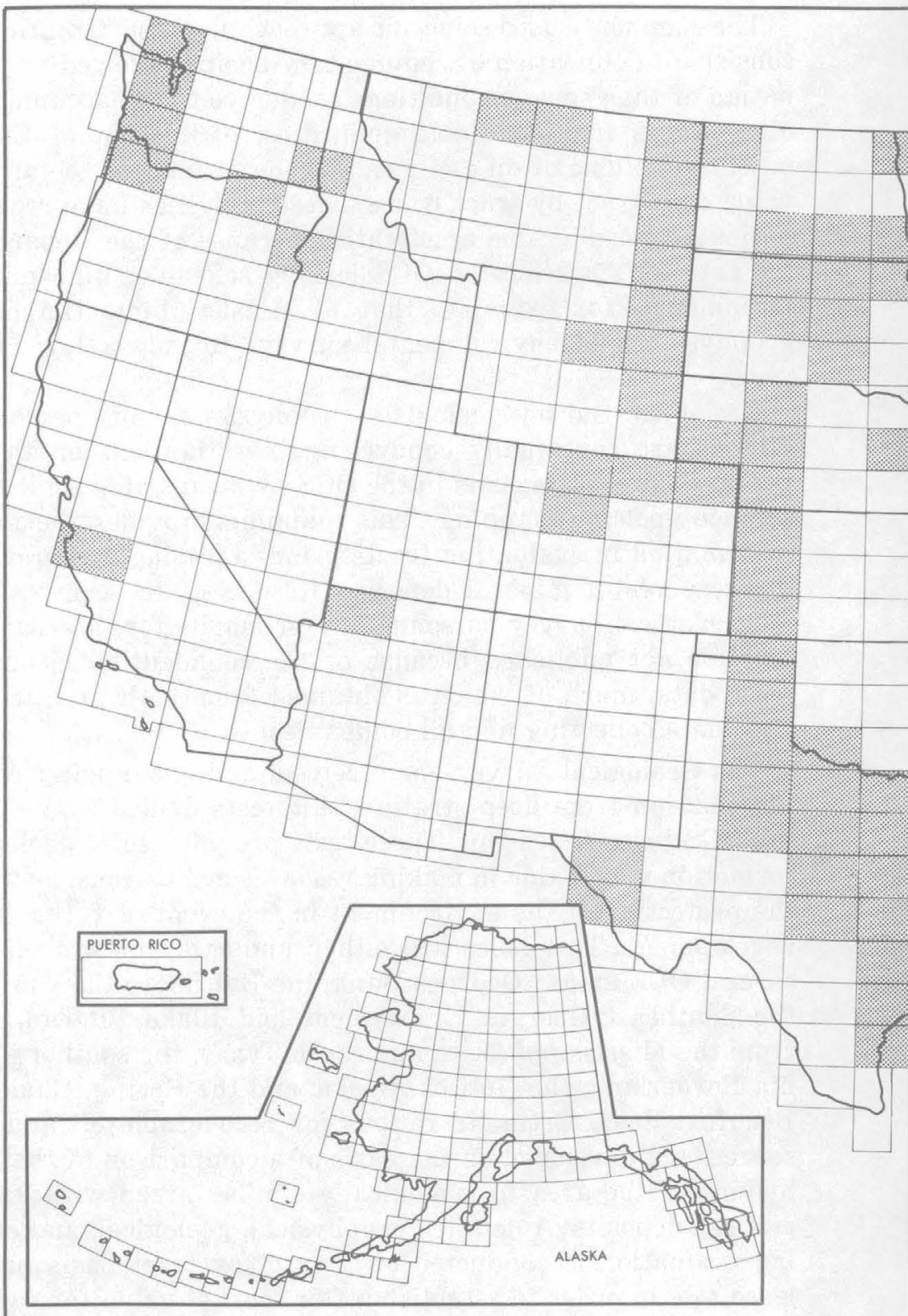

FIGURE 12.-Status of national 1:250,000-scale topographic mapping. 
APPROXIMATE SCALE

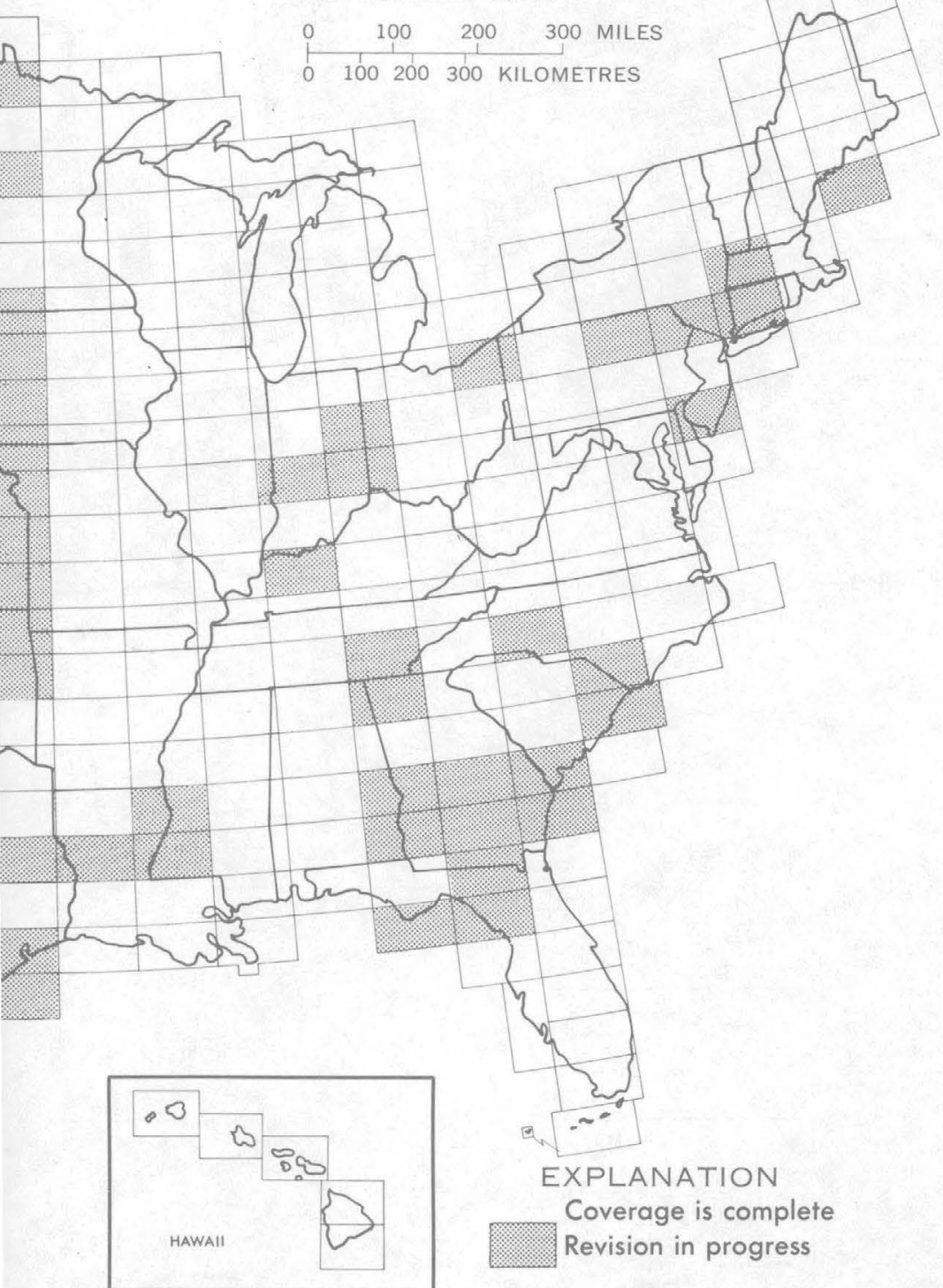




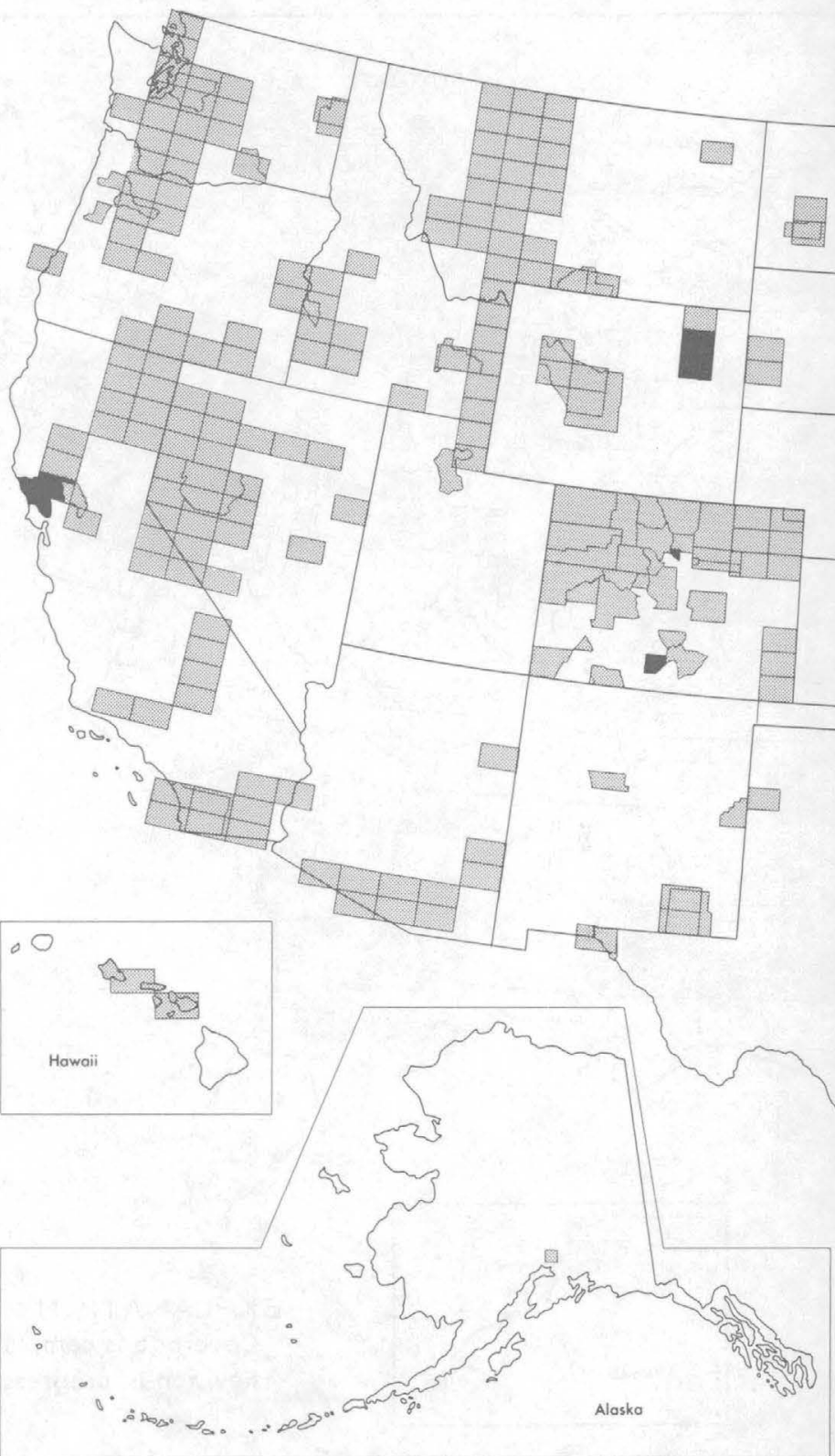

FIgURE 13.-Status of national intermediate-scale topographic mapping. 
not receiving bids remains proprietary. Oil and gas reserves are calculated and continually updated as OCS energy development proceeds.

Although the limited coal resources in coastal regions of the United States, are not being investigated at present, the processes of coal formation are under study in several States (South Carolina, Maine, and Florida) where peat deposits have been found, and their characteristics are being evaluated. In Florida they are being studied for what they may reveal about the origins of lowsulfur coal and lignite.

The principal nuclear energy sources that are increasing in demand as fuel are uranium and thorium; both commodities have been under study by the Geological Survey since 1939. Uraniumand thorium-related studies are responsible for improving our understanding of the nature and distribution of nuclear fuel resources.

Research activities are centered on determining the origin of uranium- and thorium-rich sandstone and vein-type deposits. In addition, studies of geophysical and geochemical exploration techniques (including instrument development) are underway, along with research analyzing the characteristics of structural and sedimentary basins associated with these deposits. As part of the resource assessments, a National Uranium Resource Data Bank has been established.

Studies relating to the environmental aspects of energy development complement the previously discussed energy-resource appraisal studies. The Geological Survey is responsible for providing environmental information on various aspects of energy-resource exploration and development on Federal lands including; geology, meteorology, oceanography, air and water quality, biological communities, and effects on alternative land or ocean uses. This information is provided BLM for inclusion in both draft and final environmental impact statements on energy mineral lease sales. For OCS lease sales, information is provided on terminal and storage facilities, refineries, ports, pipelines, and drilling and production platforms. This information assists in assessing the impact of oil and gas development in a particular area. During the detailed tract evaluation, potential geologic hazards which may threaten safe drilling are determined. Tracts where drilling stipulations will not adequately protect the environment are either withdrawn from the sale or are offered with additional stipulations on them. 


\section{RELATED ACTIVITIES}

Title: Resource Appraisal Group (Oil and Gas) (II-1)

Status: Ongoing FY 76

Location: Nationwide

Principal Contact: CO-1

Objective: To develop better hydrocarbon appraisal methods; to apply these methods to making estimates of the oil and gas resources of the United States and the other countries of the world on a continuing basis; and to make these estimates available to interested Government agencies and to the public.

Product:

Miller, B. M., and others, 1975, Geological estimates of undiscovered recoverable oil and gas resources in the United States: U.S. Geol. Survey Circ. $725,78 \mathrm{p}$.

Title: Characteristics of Chalk Reservoirs (II-2)

Status: Ongoing FY 76

Location: Federal Outer Continental Shelf

Principal Contact: $\mathrm{CO}-1$

Objective: To develop techniques for the recognition of potential oil and gas reservoirs in chalks. The origin and physical characteristics of chalk reservoirs are being studied in rock bodies of different geologic settings using petrographic and electron-scanning microscopy techniques, well logs, and petrographical analyses. Theoretical studies are applied to chalkreservoir problems related to the Atlantic Outer Continental Shelf province and other OCS areas where chalk reservoirs occur.

Title: Atlantic Continental Margin Geophysics (II-3)

Status: Ongoing FY 76

Location: Atlantic Continental Shelf, Slope, and Rise

Principal Contact: NR-7

Objective: To investigate the deep structure of the Continental Shelf and Slope of the Atlantic margin of the United States. Principal objectives include structural interpretations, and thickness and distribution evaluation of sedimentary rocks with emphasis on likely areas for petroleum exploration. The study is carried out using multichannel seismic profiles collected at grid intervals of 40 kilometres, with high-sensitivity aeromagnetic surveys flown between the Canadian border and Florida, and from the coast to 2,000 metres water depth. Gravity data, high-resolution seismic profiles, and seismic refraction data are also utilized.

Title: Atlantic Outer Continental Shelf Resources (II-4)

Status: Ongoing FY 76

Location: Offshore Maine, New Hampshire, Rhode Island, Connecticut, Massachusetts, New York, New Jersey, Delaware, Maryland, Virginia, North Carolina, South Carolina, Georgia, and Florida.

Principal Contact: NR-7

Objective: To assess the petroleum potential of the Atlantic Outer Continental Shelf by coordinated geological and geophysical studies conducted in the area from Florida to the northeastern edge of Georges Bank. South of Cape Hatteras, North Carolina, outcrop and well data are used to pro- 
vide control for marine geophysical surveys. Studies north of Cape Hatteras are designed to refine estimates of petroleum potential, that is, the stratigraphic interpretation of Mesozoic sediments which are expected to have the highest petroleum potential. In the Baltimore Canyon Trough and Georges Bank area, the study is examining the likelihood of petroleum traps.

Products:

Minard, J. P., Perry, W. J., Jr., Weed, E. G. A., Rhodehamel, E. C., Robbins, E. I., and Mixon, R. B., 1974, Preliminary report on geology along Atlantic continental margin of northeastern United States: Am. Assoc. Petroleum Geologists Bull. v. 58, no. 6, pt. 2, p. 1169-1178.

Perry, W. J., Jr., Minard, J. P., Weed, E. G. A., Robbins, E. I., and Rhodehamel, E. C., 1975, Stratigraphy of Atlantic coastal margin of United States north of Cape Hateras-brief survey: Am. Assoc. Petroleum Geologists bull., v. 59 , no. 9 , p. $1529-1548$.

Weed, E. G. A., Minard, J. P., Perry, W. J., Jr., Rhodehamel, E. C., and Robbins, E. I., 1974, Generalized pre-Pleistocene geologic map of the northern United States Atlantic continental margin: U.S. Geol. Survey Misc. Inv. Ser. Map I-861, scale 1:1,000,000.

\section{Title: Geology of Oil Potential, Continental Margin (II-5)}

\section{Status: Ongoing FY 76}

Location: Offshore Maine, New Hampshire, Rhode Island, Connecticut, Massachusetts, New York, New Jersey, Delaware, Maryland, Virginia, North Carolina, South Carolina, Georgia, and Florida.

Principal Contact: NR-7

Objective: To examine and collect single and multichannel continuous seismic reflection profiles to be used to infer the geometry of basins beneath the Atlantic Continental Margin having petroleum potential. The project is concerned with the development of other "trailing" edge margins. The project seeks to outline the shape and thickness of Mesozoic and Cenozoic strata above the crystalline basement. The project aims to outline areas of anomalously thick accumulation of sediment, block-faulted basement, or any other conditions that could have a bearing on petroleum accumulation.

Products:

Schlee, John, 1975, Sand and gravel, With a section by Peter Sanko: MESA New York Bight Atlas Mon. 21, 26 p. (Albany, N. Y., New York Sea Grant Inst.)

\section{Title: Site Survey Atlantic OCS (II-6)}

\section{Status: Ongoing FY 76}

Location: Offshore Maine, New Hampshire, Massachusetts, Rhode Island, Connecticut, New York, New Jersey, Delaware, Maryland, Virginia, North Carolina, South Carolina, Georgia, and Florida

Principal Contact: NR-7

Objective: The primary purpose of this project is to generate possible future shallow coring (1,000 feet ( 305 metres) maximum) sites which can disclose most effectively the age and nature of the rocks forming the United States Atlantic Continental Shelf and Slope. Another function of the work is to assure that the sites selected are not petroleum traps which would conceivably leak as a result of drilling and cause pollution of the ocean. 
Title: OCS Sale \#42 (II-7)

Status: Proposed sale date, 1977

Location: Offshore North Atlantic, Georges Bank area-Maine, New Hampshire, Massachusetts, Rhode Island, and Connecticut

Principal Contact: DC-1

Objective: Tract selection for Sale \#42 includes 206 tracts totaling 1,172,796 acres $(475,000$ hectares $)$. Evaluation of these tracts is in progress and will be completed prior to the sale.

Title: Environmental Assessment of the Atlantic Outer Continental Shelf (II-8)

Status: Ongoing FY 76

Location: Offshore New Jersey, Delaware, and Maryland

Principal Contact: NR-7

Objective: To outline the characteristics and variability of various environmental parameters within selected areas of the Outer Continental Shelf which may be leased for petroleum exploration in the future. To date, the project has been concerned with bottom instability in the Baltimore Canyon Trough area (the Continental Shelf off New Jersey, Delaware, and Maryland). By means of high-resolution seismic reflection records, bathymetric maps, and bottom-sediment samples, both by grab and core techniques, the aim is to determine the equilibrium or nonequilibrium of the surface sediments within the modern environment. Such determinations are important for decisions on specific areas to be leased and, subsequently, for safe drilling and transfer operations.

Products:

Knebel, H. J., 1974, Movement and effects of spilled oil over the Outer Continental Shelf-Inadequacy of existent data for the Baltimore Canyon Trough area: U.S. Geol. Survey Circ. $702,17 \mathrm{p}$.

Knebel, H. J., and Hardin, N. S., 1975, The responsibilities and environmental programs of the U.S. Geological Survey in the Baltimore Canyon Trough area, in Outer Continental Shelf Conf. and Workshop on Marine Environmental Implications of Offshore Oil and Gas Development in the Baltimore Canyon Region of Mid-Atlantic Coast, Proc.: Wachapreague, Virginia, Estuarine Research Federation, p. 7-17.

Sheridan, R. E., and Knebel, H. J., 1975, Evidence of youthful faulting on the Outer Continental Shelf [Abs.]: Geol. Soc. America Abs. with Programs, no. 7, p. 1268.

Title: OCS Sale \#40 (II-9)

Status: Proposed sale date, August 1976

Location: Offshore mid-Atlantic Baltimore Canyon area-Maryland, Delaware, and New Jersey

Principal Contact: DC-1

Objective: Tract selection for Sale \#40 includes 178 tracts totaling 1 million acres $(404,858$ hectares $)$. Evaluation of these tracts is in progress and will be finished prior to the sale date.

Title: Natural Resources and Tectonic Framework of the Caribbean Region (II-10)

Status: Completed FY $\mathbf{7 5}$

Location: Puerto Rico and U.S. Virgin Islands 
Principal Contact: CA-3

Objective: To compile data and publish a series of maps for regional tectonic syntheses, to evaluate potential oil and gas basins, and to evaluate metallogenic belts. A tectonic map of the Caribbean Sea and surrounding land areas has been compiled at a scale of $1: 2,500,000$ which shows rock units, folds, faults, and structure contours on several horizons. In addition, free-air and Bouguer gravity, magnetic-intensity, seismicity, and heatflow data were compiled at that scale.

Title: Appraisal of Thorium in Beach Placer Deposits (II-11)

Status: Ongoing FY 76

Location: Virginia, North Carolina, South Carolina, Georgia, and Florida

Principal Contact: NR-7

Objective: To furnish data on thorium, rare-earth, and titanium resources, which represent an important source of thorium for use in nuclear generators. The approach is to study Holocene and Pleistocene beach placers of the southern Atlantic coast to determine their distribution, extent, total heavy-mineral content, amount of titanium minerals, mode of formation, source of heavy minerals, and the environmental impact if the placers were exploited.

Title: Origin of Low-Sulfur Coal (II-12)

Status: Ongoing FY 76

Location: Florida, Georgia, and Louisiana

Principal Contact: NR-7

Objective: To map the occurrence and determine the geologic history of peat and other late Cenozoic sediments in the Everglades and other coastal swamps; to establish the geomorphic and hydrologic controls affecting the accumulation of various kinds of peat; to determine the compositional and areal variations in the properties of peat and associated sediments; to establish the sulfur content in the waters and peat and the relative importance of the various forms of sulfur; and to apply the knowledge gained to lignite deposits of the coastal plains and the Dakotas and to other ranks of coal.

Title: OCS Sale \#38-A (II-13)

Status: Held July 1975

Location: Offshore southwest Louisiana and southeast Texas from Matagorda Island to east Cameron area.

Principal Contact: LA-2

Objective: Sale \#38-A consisted of 345 tracts totaling 1.77 million acres (0.72 million hectares) Eighty tracts received bids for a total bonus of $\$ 171.4$ million. Bids on 14 tracts were rejected as insufficient. Sixty-six tracts were leased.

Product:

U.S. Department of the Interior, 1975, Final environmental statement proposed 1975 Outer Continental Shelf oil and gas general lease sale offshore central Gulf of Mexico, OCS sale No. 38: Washington, D.C., FES 75-37, 2 v.

Title: OCS Sale \#41 (II-14)

Status: Held February 1976 
Location: Gulf of Mexico offshore-Florida, Alabama, Mississippi, Louisiana, and Texas

Principal Contact: LA-2

Objective: Sale \#41 consisted of 134 tracts totaling 687,604 acres $(278,273$ hectares). Forty-one tracts received bids for a total bonus of $\$ 1.76$ million. Bids on seven tracts were rejected as insufficient. Thirty-four tracts were leased.

Product:

U.S. Department of the Interior, 1976, Final environmental statement, proposed 1976 Outer Continental Shelf oil and gas general lease sale Gulf of Mexico, OCS sale No. 41: Washington, D.C., FES 75-101, 3 v.

Title: OCS Sale \#S-1 (II-15)

Status: Held July 1974

Location: Offshore Louisiana and southeast Texas

Principal Contact: LA-2

Objective: Sale \#S-1 consisted of 258 tracts totaling 1.3 millions acres $(526,000$ hectares). This sale consisted of tracts which were not leased in the Louisiana deepwater Sale \#33 and the Texas deepwater Sale \#34. Bids were received on 49 tracts, 19 of which were accepted for a total high bonus bid of $\$ 30.2$ million. Thirty bids that did not meet Geological SurProducts : vey minimum evaluations were rejected.

Adams, M. V., and others, 1974, Mineral resource management of the Outer Continental Shelf: U.S. Geol. Survey Circ. 720, 32 p.

U.S. Department of the Interior, 1974, Final environmental statement, proposed 1974 Outer Continental Shelf oil and gas general lease sale offshore Louisiana, OCS sale No. 33: Washington, D.C., FES 74-6, 3 v.

1974 , Final environmental statement, proposed 1974 Outer Continental Shelf oil and gas general lease sale offshore Texas, OCS sale No. 34: Washington, D.C., FES 74-14, 3 v.

Title: Significance of Plate Tectonics to Petroleum Generation and Emplacement in Pacific Coast Provinces-Offshore California, Washington, and Oregon (II-16)

Status: Completed FY $\mathbf{7 5}$

Location: California, Washington, and Oregon

Principal Contact: CO-1

Objective: To apply current concepts concerning the interrelation of plate tectonics and petroleum occurrence to the geology of Pacific coast provinces and especially to the nonproductive and marginally productive provinces so as to arrive at estimates of the petroleum potential of the area.

Title: Environmental Geologic Studies of the Oregon and Washington Continental Shelf and Margin (II-17)

Status: Ongoing FY 76

Location: Offshore Oregon and Washington

Principal Contact: CA-3

Objective: To delineate and evaluate geologic hazards, such as fault disruption, sea-floor instability, excessive erosion, and deposition, along with the development of an inventory of potential sinks for introduced contaminants on the Oregon and Washington Outer Continental Shelf. 
The approach is to characterize the present geologic environment through the study of the distribution, lithology, and age of sediments and the location and character of major structural elements.

Title: Oregon-Washington Continental Margin (II-18)

Status: Ongoing FY 76

Location: Offshore Oregon and Washington

Principal Contact: CA-3

Objective: To perform geologic and geophysical mapping of the OregonWashington Continental Margin so as to unravel the geologic history and the relation of this history to mineral resources accumulation, geologic hazards, and regional tectonic and igneous events. Two tectonically distinct areas selected for detailed studies are offshore central Oregon and northernmost Washington. In both areas shale diapirs which form structures suitable for oil and gas accumulation are being investigated, as are major faults on the Oregon shelf, deposits of sand and gravel on inner shelves, and the outwash sand and gravel on the Washington shelf and in the Strait of Juan de Fuca. Information is being summarized in a tectonic map of scale 1:500,000, being prepared for the Oregon and Washington Continental Margin using data acquired by the Geological Survey and National Oceanic and Atmospheric Administration contracts with Oregon State University and the University of Washington.

Products :

Snavely, P. D., Jr., and MacLeod, N. S., 1974, Yachats Basalt-An upper Eocene differentiated volcanic sequence in the Oregon Coast Range: U.S. Geol. Survey Jour. Research, v. 2, no. 4, p. 395-403.

Snavely, P. D., Jr., MacLeod, N. S., Rau, W. W., Addicott, W. O., and Pearl, J. E., 1975, Alsea Formation-an Oligocene marine sedimentary sequence in the Oregon Coast Range: U.S. Survey Bull. 1395-F, 21 p.

Title: Aretic Environmental Studies (II-19)

Status: Ongoing FY 76

Location: Alaska

Principal Contact: CA-3

Objective: To collect and synthesize pertinent engineering-geologic data made available during construction of the trans-Alaska hot oil pipeline and data of other related structures in order to determine the adequacy of preconstruction predictive techniques related to geotechnical and environmental problems in arctic areas. Special consideration is given to the character and distribution of surficial deposits and permafrost, Pleistocene and Holocene stratigraphy, glacial chronology, periglacial features, seismic phenomena, and geologic processes that are either unique to or are especially active in the arctic environment.

Title: Cook Inlet (II-20)

Status: Ongoing FY 76

Location: Alaska

Principal Contact: CA-3

Objective: To provide a geologic framework of the lower Cook Inlet (Kalgin Island southwest) for offshore lease sales in that area. Project goals include obtaining a 500-mile (805-kilometre) network of geophysical lines involving the following: high-resolution (sparker) data, gravity 
data, and magnetic data. In certain selected areas, onshore gravity and magnetic data are to be collected. In the Seldovia area on the Kenai Peninsula and in the areas southwest of Iniskin Peninsula, Kamishak Hills, and Cape Douglas, mapping and measurement of stratigraphic sections are to be carried out.

Title: Environmental Geologic Studies of the Beaufort and Chukchi Seas (II-21)

Status: Ongoing FY 76

Location: Offshore Alaska

Principal Contact: CA-3

Objective: To obtain baseline geologic information for the poorly known environment of the Beaufort Sea. Goals are to determine the dynamic processes and avenues of sedimentation in the modern arctic environment including source areas, physical and chemical composition of bottom materials, paths and rates of movement of sediments, relation of sediment transport regime to river effluents, ice rafting, turbidity, ice gouging, and nearshore and bottom currents. The onshore portion of the project includes coring and outcrop examination for investigation of stability of geologic materials.

Title: Environmental Geologic Studies of the Eastern Gulf of Alaska (II-22)

Status: Ongoing FY 76

Location: Offshore Alaska

Principal Contact: CA-3

Objective: To investigate the Gulf of Alaska Continental Shelf, which will lead to an understanding of the geologic processes that have shaped its development and resources and that might have an adverse effect on the exploration for mineral and petroleum resources on the Continental Shelf. Sediment sampling and high-resolution geophysical profiling are used to ascertain the distribution of surface faults, the seismic history of the gulf, the movement of modern sediment, the relationships among shelf sediments, the location of potentially unstable sediment deposits, and other environmental hazards to mineral resource development.

Products :

Carlson, P. R., and Molnia, B. F., 1975, Massive submarine slide in the Gulf of Alaska [abs.]: Geol. Soc. America, Abs. with Programs, v. 7, no. 7, p. 1018.

Molnia, B. F., 1975a, Geology of Pamplona Ridge, northern Gulf of Alaska [abs.] : Am. Assoc. Petroleum Geologists Pacific Sec., Ann. Mtg. Long Beach, Calif., 1975, Program, p. 1203.

- 1975b, Surface sediment types of the northern Gulf of Alaska Continental Shelf [abs.], in Symposium on Science, Resources, and Technology in the Gulf of Alaska, Oct. 1975: [2 p.].

Molnia, B. F., and Carlson, P. R., 1975, Shelf sediment distribution: Northern Gulf of Alaska [abs.]: Am. Assoc. Petroleum Geologists, Pacific Sec., Ann. Mtg. Long Beach, Calif., 1975, Program, p. 1203.

Title: Environmental Geologic Studies of the Northern Bering Sea (II-23)

Status: Ongoing FY 76

Location: Offshore Alaska 
Principal Contact: CA-3

Objective: To study transgressive marine and continental sediments containing potentially economic quantities of gold and possible toxic amounts of mercury in nearshore areas of the Bering shelf and in intrashelf Tertiary basins which are potential petroleum provinces. Investigations focus on the age, provenance, dispersal, and depositional history of these sedimentary bodies and on defining placer and toxic metal concentrations in modern paralic environments and in ancient subsea beaches, alluvial channels and deltas.

Title: Environmental Geologic Studies of the Western Gulf of Alaska (II-24)

Status: Ongoing FY 76

Location: Offshore Alaska

Principal Contact: CA-3

Objective: To map the geophysics and geology of the sea floor and subsea floor and to assess environmental problems resulting from potential energy-mineral development of the Outer Continental Shelf of the western Gulf of Alaska. Sediment sampling and high-resolution geophysical profiling are being used to determine the distribution of surface faults, the seismic history of the gulf, the movement of modern sediment, the relationship between shelf sediment types, the location of potentially unstable sediment deposits, and other environmental hazards.

Title: Geologic Framework and Resource Assessment of the Aleutian-Bering Sea Area (II-25)

Status: Ongoing FY 76

Location: Off shore Alaska

Principal Contact: CA-3

Objective: To assess the resource potential of the summit basins of the Aleutian Ridge and the large basins of the Bering shelf. In addition, the origin of the igneous crust of the Bering Sea Basin and the thickness of of its overlying sedimentary section are being investigated. Techniques used include shipborne geophysical and geological surveys of the southern Bering Sea Shelf and adjacent Slope and Basin. Data collected include 24-channel seismic-reflection data, gravity, magnetic, bathymetric, and intermediate and high-resolution seismic-reflection data, and dredge, core, and grab samples.

Title: Geologic Framework and Resources Assessment of the BeaufortChukchi Seas (II-26)

Status: Ongoing FY 76

Location: Offshore Alaska

Principal Contact: CA-3

Objective: To perform a reconnaissance study of the geologic structure and mineral fuel potential of the Alaskan Continental Shelf and Slope in the Chukchi and Beaufort Seas using acoustic, magnetic, and gravity profiling and seabed sampling. Geophysical profile data now cover some 450,000 square kilometres of the Chukchi and Beaufort Seas and adjacent Arctic Ocean areas. 


\section{Products :}

Grantz, Arthur, Holmes, M. L., and Kososki, B. A., 1975, Geologic framework of the Alaskan continental terrace in the Chukchi and Beaufort Seas, in Yorath, C. J., Parker, E. R., and Glass, D. J., eds., Canada's contitinental margins and offshore petroleum exploration: Canadian Soc. of Petroleum Geologists Mem. 4, p. 669-700.

Title: Geologic Framework and Resource Assessment of the Eastern Gulf of Alaska (II-27)

Status: Ongoing FY 76

Location: Offshore Alaska

Principal Contact: CA-3

Objective: To investigate both the Gulf of Alaska Continental Shelf, which will lead to an understanding of the geologic processes that have shaped its development, and the envinonmental hazards which might have an adverse effect on the development of mineral and petroleum resources on the Continental Shelf. The study is carried out through sediment sampling and high-resolution geophysical profiling. Emphasis is on environmental hazards, the distribution of surface faults, the seismic history of the gulf, the movement of modern sediment, the relationship between shelf sediment types, and the location of potentially unstable sediment deposits.

Product:

Bruns, Terry, and Plafker, George, 1975, Preliminary results of a 1974 geophysical study of the offshore Gulf of Alaska Tertiary province [abs.]: Amer. Assoc. Petroleum Geologists, Pacific Sec., Ann. Mtg., Long Beach, Calif., 1975, Program, p. 32.

Title: Geologic Framework and Resources Assessment of Western Gulf of Alaska (II-28)

Status: Ongoing FY 76

Location: Offshore Alaska

Principal Contact: CA-3

Objective: To delineate the geologic framework and the geologic history of the area between Hinchinbrook-Middleton Islands to Chirikof Island just south of Kodiak in order to provide the basic data from which mineral-resource potential can be evaluated. Longer range objectives are to prepare geologic, tectonic, and geophysical maps and to determine the geologic evolution of the areas.

Title: Gulf of Alaska Tertiary Province (II-29)

Status: Ongoing FY 76

Location: Alaska

Principal Contact: CA-3

Objective: To delineate the major geologic features of a potential petroleum province, including a unique sequence of late Cenozoic marine glacial sediments. Data have been collected on the history of shoreline deformation along the coast, the rate of glacier movement, and the nature of earthquake-related flood waves at Lituya Bay. Other goals include reconnaissance-scale mapping of newly discovered Tertiary rocks in the Chugach Mountains. Results will be published on geologic maps (1:250,000 scale) for the entire 9,000-square-mile (23,310-square-kilometre) 
outcrop area of the Tertiary basin. Maps of scale 1:63,360 or larger of selected quadrangles are also planned.

Title: OCS Sale \#39 (II-30)

Status: Held April 1976

Location: Offshore Gulf of Alaska from Icy Bay to Kayak Island

Principal Contact: CA-2

Objective: Sale \#39 consisted of 189 tracts totaling 1.0 million acres $(405,000$ hectares). Bids were received on 81 tracts for a total high bonus bid of $\$ 571.9$ million.

Product:

U.S. Department of the Interior, 1976, Final environmental impact statement OCS proposed oil and gas leasing in the northern Gulf of Alaska, OCS sale No. 39: Washington, D.C., FES 75-93, 4 v.

Title: Regional Petroleum Geology, Alaska-North Slope (II-31)

Status: Ongoing FY 76

Location: Alaska

Principal Contact: CA-2

Objective: To study the Carboniferous Lisburne Group rocks in the western Brooks Range and the Cretaceous rocks along the north flank of the Brooks Range. Goals are to determine the nature of thrust sheets along the mountain front and to evaluate the hydrocarbon reservoir potential of the subsurface Lisburne in the eastern North Slope. The work includes correlations between wells and outcrop, identification of porosity trends, and determination of porosity and lithofacies relationships. North Slope geophysical data, both public and private, are used. Offshore seismic surveys in the Prudhoe Bay area are being correlated with available onshore data and wells.

Title: Central California Continental Margin (II-32)

Status: Completed FY 75

Location: Offshore California

Principal Contact: CA-3

Objective: To perform a geologic and geophysical study of the central California Continental Margin to evaluate the deep and shallow crustal structure, geologic history, relation to regional tectonics and the potential for economic commodities such as petroleum, glauconite, phosphorite, and nearshore placer deposits; and tectonic hazards of such major geologic features as the Santa Maria, Sur, Santa Cruz, Bodega, and Pt. Arena basins; the Santa Lucia, Farmallon, Santa Cruz, and Oconostota ridges; and the San Andreas, San Gregorio, and Santa Lucia bank-fault systems.

Title: Environmental Geological Studies of the Northern and Central California Continental Shelf and Margin (II-33)

Status: Ongoing FY 76

Location: Offshore California

Principal Contact: CA-3

Objective: To describe the geologic structure of the Continental Shelf and Slope, especially in areas of known and suspected active faulting. The project also includes the study of the flux of materials both natural and man-introduced, on the shelf and in adjacent estuaries, with emphasis 
on processes and rates that act as sources and sinks for hydrocarbons, trace elements and trace metals, and synthetic organic compounds. Measurements of long- and short-term sediment flux in representative hydraulic environments and assessment of areas of sea-floor instability related to seismic and aseismic events will also be undertaken.

Title: Environmental Geologic Studies of the Southern California Borderland (II-34)

Status: Ongoing FY 76

Location: Offshore California

Principal Contact: CA-3

Objective: To delineate and evaluate the environmental conditions of the proposed California oil and gas lease area. Specific goals and approaches are: to determine the locations, distribution, and ages of faulting within the borderland and to relate active faulting to the seismicity of the region; to determine the locations and distribution of sea-floor instability features such as landslides and slumps; to evaluate engineering properties of surficial sediment on the sea floor in an attempt to estimate the loadbearing parameters and stability of these materials; to inventory the locations and distribution of hydrocarbon seeps; to devise techniques for sampling and analyzing sediment samples for hydrocarbons and to devise a method for tagging hydrocarbon sources; to evaluate effects of recent sedimentary processes, including identification of areas of erosion and sedimentation and bedrock exposures, microsedimentary structures, trace elements and benthic fauna distributions, and to determine the source, locations, and distribution of contaminant pathways and traps; to identify freshwater aquifers, determine the location and distribution of potential saltwater-intrusion entrance sites into ground-water bodies, and relate these entrance sites to contaminant pathways and traps.

Title: Geologic Framework and Resources Assessment of the North and Central California Continental Shelf and Margin (II-35)

Status: Ongoing FY 76

Location: Offshore California

Principal Contact: CA-3

Objective: To compile geologic and geophysial maps for the Outer Continental Shelf and Margin of California north of $34^{\circ} 30^{\prime}$ and to establish the geologic history of this area. Five major offshore late Tertiary sedimentary basins exist in this area, and project goals include a determination of their structure, stratigraphy, geologic history, hydrocarbon sourcerock assessment, and the type, magnitude, and quality of potential reservoir rocks within each basin. Data from all available sources, from marine geological and geophysical investigations and offshore exploration wells, are being compiled, interpreted, and synthesized into maps of regional scope. Complimentary investigations on the onshore extensions of these basins will also be conducted in order to determine whether offshore basins can be viewed as analogs of onshore production areas.

Product:

Taylor, J. C., 1975, Estimating potential oil resources in the central California coastal zone: Calif. Univ., Santa Cruz, Coastal Marine Studies Spec. Pub. 3, p. 21-35. 
Title: Geologic Framework and Resource Assessment of the Southern California Borderland (II-36)

Status: Ongoing FY 76

Location: Offshore California

Principal Contact: CA-3

Objective: To compile geologic and tectonic maps of the continental borderland of southern California. Data from all available sources of marine geological and geophysical investigations are compiled, interpreted, and synthesized into maps of regional scope. These maps provide information to assist in the understanding of the stratigraphy, depositional history, structural evolution, and tectonic development of this critical area and to provide for preliminary resource and environmental evaluations.

Title: OCS Sale \#35 (II-37)

Status: Held December 1975

Location: Offshore southern California

Principal Contact: CA-2

Objective: Sale \#35 consisted of 231 tracts totaling 1.3 million acres $(526,000$ hectares). Seventy tracts received bids for a total bonus of $\$ 105.2$ million. High bids on 14 tracts were rejected as insufficient. Sixty-six tracts were leased.

Product:

U.S. Department of the Interior, 1975, Final environmental statement, proposed 1975 Outer Continental Shelf oil and gas general lease sale offshore southern California, OCS sale No. 35: Washington, D.C., FES 7568,3 v.

Title: Environmental Impact Statement, Ocala National Forest (II-38)

Status: Completed July 1974

Location: North-central Florida

Principal Contact: DC-1

Objective: To assess the environmental impact of oil and gas exploration in the Ocala National Forest. The Department of the Interior authorized exploratory oil and gas operations in the Ocala National Forest in July 1974 after all possible consequences of its approval were examined. On July 13, 1975, Amoco Production Company commenced drilling operations on well No. 1 , USA $6-4$ in the SW1/4SW1/4 sec. 6, T. 15 S., R. 20 E., Marion County, Florida, with a projected total depth of 4,500 feet (1,370 metres).

Product:

U.S. Department of the Interior, 1974, Final environmental statement, proposed oil and gas operations in the Ocala National Forest, Florida: Washington, D.C. FES 74-29.

Title: OCS Sale \#36 (II-39)

Status: Held October 1974

Location: Offshore Louisiana

Principal Contact: LA-2

Objective: Sale \#36 consisted of 297 tracts totaling 1.37 million acres $(554,000$ hectares). One hundred and fifty-seven tracts received bids for a total bonus of $\$ 1.44$ billion. High bids on 13 tracts were rejected as insufficient. One hundred and forty-four tracts were leased. 


\section{Product:}

U.S. Department of the Interior, 1974, Final environmental statement, proposed 1974 Outer Continental Shelf oil and gas general lease sale offshore Louisiana, OCS sale No. 36: Washington, D.C., FES 74-41, 3 v.

Title: OCS Sale \#38 (II-40)

Status: Held May 1975

Location: Offshore of south-central and southeast Louisiana from Vermilion to Main Pass Area

Principal Contact: LA-2

Objective : Sale $\# 38$ consisted of 283 tracts totaling 1.34 million acres $(542,000$ hectares). One hundred and two tracts received bids for a total bonus of $\$ 250$ million. High bids on 16 tracts were rejected as insufficient. EightyProduct: six tracts were leased.

U.S. Department of the Interior, 1975, Final environmental statement, proposed 1975 Outer Continental Shelf oil and gas general lease sale offshore central Gulf of Mexico, OCS sale No. 38: Washington, D.C., FES 75-37, $2 \mathrm{v}$.

Title: Core Sound Area, North Carolina (II-41)

Status: Ongoing FY 76

Location: North Carolina

Principal Contact: NR-7

Objective: To evaluate environmental factors that influence the distribution, chemical composition, and diagenesis of peaty materials in recent sediments and to characterize peaty deposits that are progenitors of coal. The project is part of a long-range systematic study of the distribution of organic material in the various environments of the Pamlico Sound area, North Carolina, of which Core Sound is a small part. Depositional environments studied in the project area are shallow-water estuarine, paludal, and littoral marine, containing largely carbonaceous sand and mud deposits with a high proportion of plant debris.

Title:Environmental Geologic Studies, South Texas Outer Continental Shelf (II-42)

Status: Ongoing FY 76

Location: Offshore Texas

Principal Contact: CO-1

Objective: To study geologic processes on the Continental Shelf. Goals include mapping of Holocene surface sediments, regional thickness patterns, internal and biogenic structures, and erosional depositional patterns; determining the paleotopography of the upper Pleistocene surface and delineating the characteristics of its deposits and their facies relations across the shelf; determining late Pleistocene-Holocene sea-level fluctuations; mapping geologic features of hazardous nature to offshore engineering development (faults, sediments that have slumped or may be subject to slumping, and excessive erosional scour); determining the amounts of trace metals in suspended and surficial sea-floor sediments and mapping their regional distribution patterns. 
Title: OCS Sale \#37 (II-43)

Status: Held February 1975

Location: Offshore of south Texas from Corpus Christi to South Padre Island Principal Contact: LA-2

Objective: Sale \#37 consisted of 515 tracts totaling 2.9 million acres (1.2 million hectares). One hundred and forty-three tracts received bids for a total bonus of $\$ 300$ million. High bids on 30 of these tracts were rejected as insufficient. One hundred and thirteen tracts were leased.

Product:

U.S. Department of the Interior, 1975, Final environmental statement, proposed 1975. Outer Continental Shelf oil and gas general lease offshore Texas, OCS sale No. 37: Washington, D.C., FES 74-63, 4 v.

\section{III.-REGIONAL GEOLOGIC AND HYDROLOGIC SURVEYS, MAPPING, AND ANALYSIS}

A fundamental aspect of all earth-science studies is the production of maps that display geologic or hydrologic data. Maps are regional representations of geologic knowledge, depicting the distribution of rocks, soils, streams, and ground water, identifying the age, origin, and physical and structural interrelationships. Information summarized in this manner is useful to the assessment of resources, to the prediction of environmental impacts, and to the planning of a rational use of the land. As an example of the utility of these products, several agencies of the State of California used Geological Survey geologic and hydrologic inventory maps in their recent formulation of coastal zone planning and legislation.

The geologic mapping program produces geologic maps in various scales depending on their purpose and intended use. Common scales are $1: 2,500,000,1: 500,000,1: 250,000,1: 100,000$, and $1: 24,000$; additionally some maps are produced at scales $1: 63,360$, $1: 62,500$, and $1: 20,000$. Table 2 indicates the types of information usually associated with each scale.

Fossils are commonly used to date the geologic strata in which they occur. Paleontologic and stratigraphic studies compile basic data on the distribution of fossils within the stratigraphic column, applying these data mainly to correlations with distant strata, but also to the study of the evolution of different forms and the interpretation of geologic history.

Hydrologic Investigation Atlases, which summarize the water resources of a specific basin or depict areas inundated by past floods, are produced by the Geological Survey. These atlases are designed to display detailed hydrologic information using maps, geologic profiles, tables, graphs, and block diagrams. Short bibliographies are also included. Hydrologic Investigation Atlases are 
TABLE 2.-Scales of geologic maps commonly produced by the U.S. Geological Survey

\begin{tabular}{|c|c|c|}
\hline Scale & Type of Information & Purpose \\
\hline $\begin{array}{l}1: 2,500,000 \\
\quad(1 \text { inch }=40 \mathrm{miles})\end{array}$ & $\begin{array}{l}\text { General distribution of } \\
\text { limited number of large } \\
\text { and heterogeneous rock } \\
\text { units. No information } \\
\text { on depth. No topo- } \\
\text { graphic base. }\end{array}$ & $\begin{array}{l}\text { General planning and } \\
\text { resource evaluation } \\
\text { over large regions } \\
\text { (Federal regions and } \\
\text { large States). }\end{array}$ \\
\hline $\begin{array}{l}1: 500,000 \\
\quad(1 \text { inch }=8 \text { miles })\end{array}$ & $\begin{array}{l}\text { General distribution of a } \\
\text { larger number of some- } \\
\text { what less heterogeneous } \\
\text { rock units. Little } \\
\text { information on depth. } \\
\text { No topographic base. }\end{array}$ & $\begin{array}{l}\text { General planning and } \\
\text { resource evaluation } \\
\text { over large regions } \\
\text { (large States and river } \\
\text { basins). Common scale } \\
\text { for older State maps. }\end{array}$ \\
\hline $\begin{array}{l}1: 250,000 \\
\quad(1 \text { inch }=4 \text { miles })\end{array}$ & $\begin{array}{l}\text { Semidetailed distribution } \\
\text { of large numbers of } \\
\text { fairly homogeneous rock } \\
\text { units. Some information } \\
\text { on depth. Often has } \\
\text { topographic base. }\end{array}$ & $\begin{array}{l}\text { More detailed planning } \\
\text { and resource evalua- } \\
\text { tion in medium-sized } \\
\text { areas (small States, } \\
\text { large counties, national } \\
\text { forests, and mineral- } \\
\text { ized belts). }\end{array}$ \\
\hline $\begin{array}{l}1: 100,000 \\
(1 \text { inch }=1.6 \text { miles }), \\
1: 63,360 \text { (Alaska) } \\
(1 \text { inch }=1 \text { mile }), \text { and } \\
1: 62,500 \text { (1 inch= } \\
0.99 \text { miles })\end{array}$ & $\begin{array}{l}\text { Detailed distribution of } \\
\text { large number of homo- } \\
\text { geneous rock units with } \\
\text { considerable informa- } \\
\text { tion on thickness and } \\
\text { depth. Generally has } \\
\text { topographic base. }\end{array}$ & $\begin{array}{l}\text { Detailed planning and } \\
\text { land management } \\
\text { (mining districts, } \\
\text { urban areas, and many } \\
\text { counties). }\end{array}$ \\
\hline $\begin{array}{l}1: 24,000 \\
(1 \text { inch }=2,000 \mathrm{ft}) \\
1: 20,000 \text { (Puerto Rico) } \\
(1 \text { inch }=1,667 \mathrm{ft})\end{array}$ & $\begin{array}{l}\text { Very Detailed distribution } \\
\text { of large number of } \\
\text { homogeneous rock units. } \\
\text { Surficial deposits may } \\
\text { be shown on separate } \\
\text { map. Much information } \\
\text { on thickness and verti- } \\
\text { cal extent of rock units. }\end{array}$ & $\begin{array}{l}\text { Detailed planning, zon- } \\
\text { ing, site selection, } \\
\text { and resource evalua- } \\
\text { tion and exploration } \\
\text { (cities and towns, } \\
\text { subdivisions, mining } \\
\text { districts, mine sites, } \\
\text { and large construction } \\
\text { projects). }\end{array}$ \\
\hline
\end{tabular}

designed to assist planners and designers in the rapid and accurate appraisal of the salient hydrologic features of an area. Information is provided on a variety of hydrologic topics, including local flood stages due to extraordinary storms, profiles of water surfaces during floods, availability of ground water and surface water, and the concentration of some chemical element or compound in a specific aquifer or watercourse. Map scales vary widely, depending on the size of the study area and the need for focusing on a particular hydrologic feature.

The Geological Survey's flood-prone area mapping program began in 1969, in cooperation with the Federal Insurance Agency of the Department of Housing and Urban Development, to help establish approximate flood zones as required by the National 
Flood Insurance Act of 1968. The boundaries of the 100-year flood were prepared on 1:24,000-scale Geological Survey topographic quadrangle maps. The 100-year flood boundary is used by the Federal Insurance Administration to determine areas which qualify for a federally supported flood-insurance guarantee. Maps of flood-prone areas covering nearly all urbanized parts of the Nation's coastal zone have been prepared. The maps are frequently requested by planners, developers, State and local officials, and the general public as an aid in resolving future flood-plain management problems. Copies of "flood-prone area" maps may be obtained free from district offices of the Geological Survey, located in each State.

The passage of the Federal Disaster Protection Act of 1973 required highly detailed flood data to assist the Federal Insurance Administration in enforcing the Act's provisions. The Federal Insurance Administration requested that the Geological Survey make flood-insurance studies of selected urban areas. These detailed studies are summarized in reports which provide 100 -year and 500-year flood boundaries on the most accurate large-scale maps available, as well as profiles of selected floods from 10-year to 500-year recurrence intervals. The study areas are divided into zones, each having a specific flood potential or hazard. The special flood-flow characteristics of each zone are clearly outlined in the reports. In addition to assisting Federal authorities, these reports are of considerable interest to State and local officials and to the construction industry in developing flood-plain management policies.

\section{RELATED ACTIVITIES}

Title: Mesozoic and Cenozoic Marine Paleontologic Studies-Modern Foraminifers, Gulf and Atlantic Shelf (III-1)

Status: Ongoing FY 76

Location: Offshore Maine, New Hampshire, Rhode Island, Connecticut, Massachusetts, New York, New Jersey, Delaware, Maryland, Virginia, North Carolina, South Carolina, Georgia, and Florida.

Principal Contact: NR-7

Objective: To determine the patterns and causes of the distribution of modern benthic foraminifers on the Continental Shelf and Slope of the Gulf of Mexico and western North Atlantic Ocean. Electron and optical microscopy and statistical methods will be used.

Title: Recent Foraminifers, Atlantic Shelf (III-2)

Status: Ongoing FY 76

Location: Off shore Maine, New Hampshire, Rhode Island, Connecticut, Massachusetts, New York, New Jersey, Delaware, Maryland, Virginia, North Carolina, South Carolina, Georgia, and Florida. 
Principal Contact: NR-7

Objective: To evaluate distribution patterns and environmental controls, in terms of both relative and absolute abundances of the species, and to investigate species diversity and spatial distribution of the forminiferal assemblages. Foraminiferal faunas from over 2,000 recent samples on the Atlantic Margin from Maine to Florida are being studied.

\section{Title: Northern Coastal Plain (III-3)}

Status: Ongoing FY 76

Location: Massachusetts, New York, New Jersey, Delaware, Maryland, Virginia, and North Carolina

Principal Contact: NR-7

Objective: To construct a skeletal geologic framework for the Atlantic Coastal Plain physiographic province which will aid in correlations along strike and downdip under the shelf, facilitating the location of mineral resources of possible economic significance. This information is pertinent to the relationship between offshore petroleum-resource development and the protection of environmental variables.

\section{Products:}

Minard, J. P., 1974, Geology of the Betterton quadrangle, Kent County, Maryland and a discussion of the regional stratigraphy: U.S. Geol. Survey Prof. Paper 816, 27 p.

- 1974, Slump blocks in the Atlantic Highlands of New Jersey: U.S. Geol. Survey Prof. Paper 898, 24 p.

Minard, J. P., Perry, W. J., Jr., Weed, E. G. A., Rhodehamel, E. C., Robbins, E. I., and Mixon, R. B., 1974, Preliminary report on geology along Atlantic continental margin of northeastern United States: Am. Assoc., Petroleum Geologists Bull., v. 58, No. 6, Pt., 2 p. 1169-1178.

Perry, W. J., Jr., and others, 1975, Stratigraphy of Atlantic coastal margin of U.S. north of Cape Hatteras-brief survey: Am. Assoc. Petroleum Geologists, v. 59, no. 9, p. 1529-1548.

Weed, E. G. A., and others, 1974, Generalized pre-Pleistocene geologic map of the northern United States Atlantic continental margin: U.S. Geol. Survey Misc. Inv. Ser. Map I-861, 2 sheets, scale 1:1,000,000.

Title: Mesozoic and Cenozoic Marine Paleontologic Studies-Biostratigraphy of the Atlantic Continental Margin (III-4)

Status: Ongoing FY 76

Location: Offshore Massachusetts, New York, New Jersey, Delaware, Maryland, Virginia, North Carolina, South Carolina, Georgia, and Florida.

Principal Contact: NR-7

Objective: To collect and analyze dredge and core samples from the Atlantic Continental Margin. The goals of the project include: biostratigraphic analysis of Continental Margin deposits by the use of ostracodes and calcareous nannofossils; correlating of offshore and onshore Mesozoic and Cenozoic marine deposits; describing the paleobiogeography of ostracodes and calcareous nannofossils; and describing the paleoenvironment of the Continental Margin.

Title: Cenozoic and Mesozoic Stratigraphy of Gulf and Atlantic Coastal Plains-Cretaceous Gastropods and Stratigraphies, Atlantic and Gulf Coastal Plains (III-5) 
Status: Ongoing FY 76

Location: New Jersey, South Carolina, Alabama, and Mississippi

Principal Contact: NR-7

Objective: To study the Cretaceous biostratigraphy and analyze the paleoenvironment of the New Jersey Coastal Plain and Cretaceous deposits of the Chattahoochee River region. The study is centered around the integration of the molluscan zonation of these deposits with the zonations based upon the planktonic Foraminifera and nannofossils. Field activities include detailed collections of the fauna of the Eutaw Formation and Selma Group rocks in the Tombigbee River drainage arda of western Alabama and east-central Mississippi.

Title: Mesozoic and Cenozoic Marine Diatoms, Atlantic Coastal Plain (III-6)

Status: Ongoing FY 76

Location: Maryland, Virginia, North Carolina, South Carolina, Georgia, and Florida

Principal Contact: NR-7

Objective: To determine the stratigraphic ranges of diatom genera and species in the marine Mesozoic and Cenozoic strata of the Atlantic and Gulf Coastal Plains. Diatom assemblages from this area will be used in determining the paleoecology of the Coastal Plain sediments and in geologic Product: age determination and stratigraphic correlation on a worldwide basis.

Andrews, G. W., 1974, Systematic position and stratigraphic occurrence of the marine Miocene diatom Raphidodiscus marylandicus Christian: Nova Hedwigia, Beiheft 45, p. 231-243.

Title: Stratigraphic Studies of the Miocene, Atlantic Coastal Plain (III-7) Status: Ongoing FY 76

Location: New Jersey, Maryland, Virginia, and North \Carolina

Principal Contact: NR-7

Objective: To assist in the description of the tectonic history of the Atlantic Coastal Plain by studying the distribution, paleoenvironmental relationships, stratigraphic significance, and taxonomy of the Foraminifera and several groups of Mollusca in the Miocene strata of the Atlantic Coastal Plain.

Title: Cenozoic and Mesozoic Stratigraphy of Gulf and Atlantic Coastal Plains Cenozoic Vertebrates, Eastern North America (III-8)

Status: Ongoing FY 76

Location: Maryland, Virginia, North Carolina, South Carolina, Georgia, Florida, Alabama, Mississippi, and Louisiana

Principal Contact: NR-7

Objective: To study the Cenozoic terrestrial and marine mammals from the Atlantic and Gulf Coastal Plains. Goals are to reconstruct land and sea paleoecology, make evolutionary studies of marine mammals, and to improve correlation with terrestrial deposits of the Rocky Mountain area (by studying land mammals) and the west coast of the United States.

Title: Cenozoic and Mesozoic Stratigraphy of Gulf and Atlantic Coastal Plains-Upper Cenozoic Mollusks and Stratigraphy-Atlantic Coastal Plain (III-9)

Status: Ongoing FY 76 
Location: Florida, Georgia, Maryland, North Carolina, South Carolina, and Virginia

Principal Contact: NR-7

Objective: A biostratigraphic and lithostratigraphic analysis is being performed on upper Cenozoic deposits of the Atlantic Coastal Plain to assist in reconstructing the geologic history of this area. Other tasks include the mapping and biostratigraphic and lithostratigraphic analysis of the rocks of the Coastal Plain.

Products:

Mcintyre, I. G., Blackwelder, B. W., Land L. S., and Stuckenrath, Robert, 1975, North Carolina shelf-edge sandstone: Age, environment of origin, and relationship to pre-existing sea levels: Geol. Soc. America Bull., v. 86, no. 8, p. 1073-1078.

Ward, L. W., and Blackwelder, B. W., 1975, Chesapecten, a new genus of Pectinidae (Mollusca:Bivalvia) from the Miocene and Pliocene of eastern North America: U.S. Geol. Survey Prof. Paper 861, 24 p.

Title: Cenozoic Stratigraphic Paleontology, Pacific Coast (III-10)

Status: Ongoing FY 76

Location: California, Oregon, Washington, and Alaska

Principal Contact: CR-3

Objective: To integrate previous paleontologic studies with multidisciplinary Geological Survey projects in the marine Cenozoic basins in the Pacific Coast States and Alaska. The primary research goal is the refinement of the marine invertebrate chronology of the Pacific Coast Cenozoic province through continuing biostratigraphic and taxonomic studies of shallowwater molluscan invertebrate faunas. Secondary objectives are paleoecological studies and environmental reconstruction, zoogeographic analysis, and paleoclimatic analysis.

Title: Cenozoic and Mesozoic Stratigraphy, Pacific Coast and AlaskaCenozoic Vertebrates, Pacific Coast (III-11)

Status: Ongoing FY 76

Location: California, Oregon, Washington, and Alaska

Principal Contact: CA-3

Objective: To provide age and faunal data for Tertiary and Quaternary formations in California, western Oregon, Washington, and Alaska.

Products :

Addicott, W. O., 1975a, Early Miocene age of the Clallam Formation, western Washington: U.S. Geol. Survey Bull. 1405-A, p. A26.

1975b, Provincial age and correlation of the Clallam Formation, northwestern Washington [abs.]: Geol. Soc. America, Abs. with Programs, v. 7 , no. 3, p. 289.

Allison, R. C., and Addicott, W. O., 1976, The North Pacific Miocene record of Mytilus (Plicatomytilus), a new subgenus (Bivalvia), U.S. Geol. Survey Prof. Paper 962, 21 p. [in press].

Snavely, P. D., Jr., MacLeod, N. S., Rau, W. W., Addicott, W. O., and Pearl, J. E., 1975, Alsea Formation-an Oligocene marine sedimentary sequence in the Oregon Coast Range: U.S. Geol. Survey Bull. 1395-F, 21 p.

Title: Cenozoic Floras of Alaska and the Pacific Northwest (III-12)

Status: Ongoing FY 76

Location: Oregon, Washington, and Alaska 
Principal Contact: CA-3

Objective: To study plant megafossils of Tertiary age from Alaska, Oregon, and Washington.

Title: Alaskan Gravity Surveys (III-13)

Status: Ongoing FY 76

Location: Alaska

Principal Contact: CA-3

Objective: To prepare a Bouguer anomaly map of the State of Alaska with a 10-milligal contour interval at a scale of 1:2,500,000 which is similar to the present gravity map of the conterminous United States. The map will be based primarily on data obtained from onshore and offshore traverses. The project includes a study of gravitational fields associated with the major topographic and geologic features, a study of isostatic adjustment, the estimation of regional gradients, and the location of thick sedimentary accumulations suitable for more detailed petroleum exploration. A controlled network of base stations and gravimeter calibration loops now provides control for most commercial and university gravity surveys in Alaska. This network is now being converted to the datum of the International Gravity Standardization Net.

\section{Title: Craig 1:250,000 quadrangle (III-14)}

Status: Ongoing FY 76

Location: Alaska

Principal Contact: CA-3

Objective: To establish the necessary stratigraphic and structural controls, which will facilitate correlations around the northern Pacific. This will include the estabiishment of biostratigraphic standards for Paleozoic rocks of the Cordilleran geosyncline in Alaska. A subtask will complete a

\section{Products :} modern geologic map of the Craig quadrangle at a scale of 1:250,000.

Churkin, Michael, Jr., 1974a, Deep sea drilling for landlubber geologistsThe southwest Pacific, an accordion plate tectonic analog for the Cordilleran geosyncline: Geology, v. 2, no. 7, p. 339-342.

1974b, Paleozoic marginal ocean basin-volcanic arc systems in the Cordilleran foldbelt, in Modern and ancient geosynclinal sedimentation: Soc. Econ. Paleontologists and Mineralogists Spec. Pub. 19, p. 174-192.

Churkin, Michael, Jr., and McKee, E. H., 1974a, Subcontinental crust of the Great Basin-inherited from Paleozoic marginal ocean basins? [abs.]: Geol. Soc. America, Abs. with Programs v. 6, no. 3, p. 155.

$1974 \mathrm{~b}$, Thin and layered subcontinental crust of the Great Basin, western North America, inherited from Paleozoic marginal ocean basins: Tectonophysics, v. 23, no. 1, p. 1-15.

Tchudinova, I. I., Churkin, Michael, Jr., and Eberlein, G. D., 1974, Devonian syringoporoid corals from southeastern Alaska: Jour. Paleontology, v. 48 , no. 1 , p. 124-134.

Title: Northern and Central California Tectonic Studies (III-15)

Status: Ongoing FY 76

Location: California

Principal Contact: CA-3 
Objective: To determine the pre-Miocene history of the San Andreas fault and its influence on the tectonic and sedimentary history of California duing the Late Cretaceous and Tertiary periods. The history of movement is being studied by determining offsets of strata that once extended across the fault but are now displaced by as much as hundreds of kilometres. By determining off sets of rocks of various ages along the San Andreas and other strike-slip faults, the pattern, amounts, and times of active movement can be determined. The influence of the fault on sedimentation and tectonics is being studied by careful sedimentologic and stratigraphic analyses, combined with detailed paleontologic work, of various basins along, within, and adjacent to the San Andreas fault. These studies can delineate the activity and type of movement on the fault and its influence and effects on paleogeography.

\section{Products :}

Nilsen, T. H., Brabb, E. E., and Simoni, T. R., Jr., 1975, The Nation River Formation a late Devonian deep-sea fan deposit in east-central Alaska [abs.]: Abs. with Program Alaska Geol. Soc. Symposium on recent and ancient sedimentary environments in Alaska, Anchorage p. 7.

Nilsen, T. H., and Clarke, S. H., Jr., 1975, Sedimentation and tectonics in the early Tertiary continental borderland of central California: U.S. Geol. Survey Prof. Paper 925, $64 \mathrm{p}$.

Nilsen, T. H., Dibblee, T. W., Jr., and Howell, D. G., 1975, Offsets of lower Tertiary strata in the Transverse Ranges of California by the San Andreas fault [abs.]: Geol. Soc. America, Abs. with Programs, v. 7, no. 3, p. 356 .

Nilsen, T. H., and Link, M. H., 1975, Stratigraphy, sedimentology and off set along the San Andreas fault of Eocene to lower Miocene strata of the northern Santa Lucia Range and the San Emigdio Mountains, Coast Ranges, central California [abs.]: Am. Assoc. Petroleum Geologists Pacific Sec. Ann. Mtg., Long Beach, Calif., 1975, Program, p. 629.

Wright, R. H., and Nilsen, T. H., 1975, New U.S. Geological Survey map [MF-550] quantifies the distribution of landslides: California Geology, v. 28 , no. 4 , p. 2 .

Title: Environmental Geology San Francisco Bay Region Part C-Flatlands Materials (III-16)

Status: Completed FY 75

Location: California

Principal Contact: CA-3

Objective: To map and differentiate the Quaternary geologic deposits of the San Francisco Bay. Engineering properties, geologic processes and hazards were investigated to assist future planning activities.

Title: Connecticut Cooperative Geologic Program (III-17)

Status: Ongoing FY 76

Location: Connecticut

Principal Contact: NR-7

Objective: To map and publish the bedrock and surficial geology of the State at the 1:24,000 scale on an intermittent basis and compile bedrock and surficial maps of the State at the scale of $1: 125,000$. 
Title: Flood Inundation Mapping, Northeastern Illinois (III-18)

Status: Ongoing FY 76

Location: Northeast Illinois

Principal Contact: IL-1

Objective: To provide readily understood flood information to decisionmakers.

Title: Blue Hill and Catine Quadrangles (III-19)

Status: Ongoing FY 76

Location: Maine

Principal Contact: NR-7

Objective: To construct detailed bedrock geological maps containing information on major regional fault and fold patterns, regional stratigraphy, paleontologic and isotopic geochronology, and polymetamorphism. The relationship of base metal mines to the Castine Volcanics, granitic intrusions, faulting, and metamorphism is also being studied.

Products:

Stewart, D. B., 1974, Precambrian rocks of Seven Hundred Acre Islands and development of cleavage in the Islesboro Formations, in New England Intercollegiate Geol. Conf., 66th Ann. Mtg., Orono, Me., Oct. 12-13, 1974, Guidebook for fieldtrips in east-central and north-central Maine: Orono, Me., Univ. Maine, p. 86-98.

Stewart, D. B., and Wones, D. R., 1974, Bedrock geology of northern Penobscot Bay area, in New England Intercollegiate Geol. Conf., 66th Ann. Mtg., Orono, Me., Oct. 12-13, 1974, Guidebook for fieldtrips in east-central and north-central Maine: Orono, Me., Univ. Maine, p. 223-239.

Title: Orland Quadrangle, Lucerne Pluton, Maine (III-20)

Status: Ongoing FY 76

Location: Maine

Principal Contact: NR-7

Objective: To establish the geologic setting, chemistry, and crystallization history of Lucerne Pluton, Maine, and other granitic plutons in the New England States; to establish the stratigraphy, structure, and metamorphic rocks north of Penobscot Bay; and to determine the extent of the mineralized areas and the relationship of those areas to bedrock geology. Information is coordinated with surficial geologic and geophysical data in order to contribute to geologic studies of Maine coastal areas and structures underlying the Gulf of Maine.

Product:

Wones, D. R., 1974, Igneous petrology of some plutons in the northern part of the Penobscot Bay area in New England Intercollegiate Geol. Conf., 66th Ann. Mtg. Orono, Me., Oct. 12-13, 1974, Guidebook for fieldtrips in east-central and north-central Maine: Orono, Me., Univ. Maine, p. 99-125.

Title: Maryland Cooperative Project (III-21)

Status: Ongoing FY 76

Location: Maryland

Principal Contact: NR-7

Objective: To produce a Bouguer gravity map of Maryland. This project is being conducted jointly by the Maryland Geological Survey and the U.S. Geological Survey. Gravity measurements are being made at an average spacing of about one per 2 square miles ( 5 square kilometres) in the 
central part of the State where the crystalline rocks are at or near the surface and at somewhat wider spacing for the remaining area. The study will assist in the interpretation of the regional geological structure of Maryland.

\section{Title: Massachusetts Cooperative Geologic Program (III-22)}

Status: Ongoing FY 76

Location: Massachusetts

Principal Contact: NR-7

Objective: To map and publish the bedrock and surficial geology of Massachusetts at the 1:24,000 scale on an intermittent basis and compile bedrock and surficial maps of the Commonwealth at the scale of $1: 125,000$. Aeromagnetic maps have been published for the entire Commonwealth except for the outer tip of Cape Cod and the offshore islands of Martha's Vineyard and Nantucket at the scale of 1:24,000.

Products:

Nelson, A. E., 1974a, Changes in nomenclature of upper Precambrian to lower Paleozoic(?) formations in the Natick quadrangle, eastern Massachusetts, and their tentative correlations with rocks in Rhode Island and Connecticut: U.S. Geol. Survey Bull. 1395-E, 14 p.

1974b, Surficial geologic map of the Natick quadrangle, Norfolk, and Middlesex Counties, Massachusetts: U.S. Geol. Survey Geol. Quad. Map GQ-1151, scale $1: 24,000$.

Oldale, R. N., 1974a, Geologic map of the Dennis quadrangle, Barnstable County, Cape Cod, Massachusetts: U.S. Geol. Survey Geol. Quad Map GQ-1114, scale 1:24,000.

1974b, Geologic map of the Hyannis quadrangle, Barnstable County, Cape Cod, Massachusetts: U.S. Geol. Survey Geol. Quad Map GQ-1158, scale $1: 24,000$.

1975, Geologic map of the Sandwich quadrangle, Barnstable County, Cape Cod, Massachusetts: U.S. Geol. Survey Geol. Quad Map GQ-1222, scale 1:24,000.

Volckmann, R. P., 1975, Surficial geologic map of the Medfield quadrangle, Norfolk and Middlesex Counties, Massachusetts: U.S. Geol. Survey Geol. Quad, Map GQ-1218, scale 1:24,000.

Title: Flood Hazard Information, House Document 465 (III-23)

Status: Ongoing FY 76

Location: Michigan

Principal Contact: $\mathrm{MI}-1$

Objective: To outline flood-prone areas on existing U.S. Geological Survey maps in response to the national program to provide flood-hazard information.

Title: Puerto Rico Cooperative Geologic Mapping (III-24)

Status: Ongoing FY 76

Location: Puerto Rico

Principal Contact: NR-7

Objective: To produce detailed, large-scale $(1: 20,000)$, multipurpose geologic quadrangle maps of Puerto Rico. The maps are intended to provide basic and derivative geologic data required by the Commonwealth for the effective use of rock, mineral, and land resources in programs of public works, 
conservation, recreation, and industrial and economic development. This project is a cooperative effort with the Puerto Rico Department of Natural Resources and will continue until geologic mapping of the island is complete. Special purpose and derivative maps pertinent to problems and prospects of land and mineral resource utilization in Puerto Rico will also be produced.

Title: Cape Flattery Area, Washington (III-25)

Status: Ongoing FY 76

Location: Washington

Principal Contact: CA-3

Objective: To establish the geologic evaluation of the Continental Shelf adjacent to parts of Washington. This project involves geologic mapping (scale 1:48,000) and stratigraphic, structural, and petrologic studies of the Cape Flattery area, in the northwestern Olympic Peninsula of Washington, and also reconnaissance geologic studies of selected coastal areas in western Washington. Mineral resources potential, geologic hazards, and the land use problems are being evaluated.

\section{IV.-EARTHQUAKE AND VOLGANIC HAZARDS}

Natural disasters, such as earthquakes and volcanic eruptions, can cause serious loss to life and property. The average annual national loss from earthquakes is about $\$ 630$ million, but a single large earthquake in a large metropolitan area could cause damages up to $\$ 50$ billion. Events, such as the eruption of Mauna Loa, Hawaii, on July 5-6, 1975, increased thermal emissions on Mount Baker since March 1975, and the San Fernando, California, earthquake of 1971, have accentuated the concern for better prediction of the events and the need for mitigation of their effects wherever possible.

Coastal States which have experienced damaging earthquakes recently include California, Alaska, Hawaii, and Washington, but past records indicate that several other States and regions are susceptible to them. Most of the U.S. earthquake-prone regions are coastal: New England and the Southeast Atlantic and the Pacific coastal areas are most vulnerable. Because 15 percent of the population (31 million people) live in areas of high risk, the hazards to life are great.

The earthquake hazard program has been established in response to these concerns. It evolved under the guidance of several agencies (Coast and Geodetic Survey, Environmental Science Services Administration, National Oceanic and Atmospheric Administration, and the National Science Foundation) and is conducted in cooperation with the Energy Research and Development Administration, Nuclear Regulatory Commission, Advanced Research Projects Administration, and others. 
The Geological Survey is responsible for and conducts all earthscience studies on earthquake hazards and their reduction. The Geological Survey also conducts seismic-engineering studies on behalf of the National Science Foundation, the goal of which is to help mitigate the destructive effects of these events. Major program objectives include acquisition and dissemination of information on earthquake occurrences, mapping evaluation of earthquake hazards, and developing a capability to predict the place, time and magnitude of earthquakes. Seismic activities are monitored around the clock by various recording systems and seismological observatories operated by the Geological Survey. The Geological Survey's National Earthquake Information Service (NEIS) provides information on the location and magnitude of earthquakes using data from its seismic networks and those of cooperating institutions. NEIS supplies a wide range of information services to the public in response to direct inquiry. Monitoring of local earthquake occurrences is done by networks of seismic instruments established in various States. California, Washington, Alaska, and South Carolina are four coastal States in which seismographs are located. A particularly well-known study site is near Hollister, Calif., where a dense network of seismometers, tiltmeters, magnetometers, and strain-recording instruments are deployed in an ongoing experiment to predict earthquakes in the California coastal area. In cooperation with the National Science Foundation, the Geological Survey also operates the Worldwide Network of Standard Seismographs consisting of 31 continuously recording stations in the United States and 85 other stations in 68 countries.

Volcano hazards studies are directed toward hazards prediction and mitigation in areas of active volcanoes in Hawaii and the Cascade Range. The major program effort is expended at the Hawaiian Volcano Observatory where the active volcanoes of Kilauea and Mauna Loa are monitored. In cooperation with HUD, volcano hazards maps at a scale of $1: 7,500,000$ have been prepared for the Island of Hawaii.

Selection of suitable sites for nuclear reactors must take geologic processes into account. Siting and design of reactors to avoid the hazards posed by volcanic eruptions and earthquakes can increase the cost of construction. It is critical to locate nuclear reactors in safe environments while also attempting to ensure low construction costs. As part of research into the environmental aspects of energy production, reactor hazards studies are designed to identify and to evaluate the geologic hazards to which reactors 
may be subject and in this manner to provide technical advice to both government and industry, assisting their efforts to assure safe siting of nuclear power facilities. The studies do not select specific sites for reactors, as this remains the responsibility of electric utilities. More than $\mathbf{7 5}$ percent of the reactors being built will be located in the eastern part of the Nation and many of them in the coastal zone. To help with site selection, the Geological Survey is studying the geologic structure and recency of faulting in New England, New York, and the Atlantic Coastal Plain. In the Gulf Coastal Plain, where surface faulting is a potential hazard, the relationship between ground-water withdrawal and surface faulting is undergoing examination. In the western region, geologic mapping is done in California, Washington, and Oregon in association with hazards assessment (faulting, earthquakes, volcanic activity, and ground-water withdrawal).

Problems unique to arctic environments are being examined by arctic environmental studies and the Alaska pipeline related investigations activities. Construction of the Alaska pipeline from Prudhoe Bay to Valdez presented an opportunity to investigate the changes brought upon the pristine environment by man's activities. Special attention has been given to procedures for safeguarding against pollution and environmental damage related to permafrost, glaciers, and surficial deposits. The study has included monitoring of seismic activity and evaluation of potential flood and earthquake hazards. The program is also responsible for assessing engineering problems such as locating geological materials suitable for construction.

\section{RELATED ACTIVITIES}

Title: Alaska Geologic Earthquake Hazards (IV-1)

Status: Ongoing FY 76

Location: Alaska

Principal Contact: CA-3

Objective: To evaluate and suggest measures for reducing the risks resulting from ground displacement, seismic shaking, and the secondary geologic effects of earthquakes in Alaska. A more general goal is to gain an insight into tectonic processes within the seismically active zone of southern Alaska. Initial research efforts are in the highly seismic and more densely populated southern part of the State. The studies involve preparation of detailed maps of active surface faults and evaluation of geologic evidence for late Cenozoic fault movement; delineation of coastal areas that may be subjected to major earthquakes characterized by large-scale regional tectonic elevation changes and assessment of the hazards related to such movements; and identification and evaluation of secondary geologic hazards related to seismic shaking in critical areas of high population density and along transportation routes. 
Title: Alaska Seismic Studies (IV-2)

Status: Ongoing FY 76

Location: Alaska

Principal Contact: CA-3

Objective: To delineate seismically active faults, to assess seismic risks, to determine the focal mechanism of earthquakes, to investigate current tectonic deformation, and to study the structural and physical properties of the crust and upper mantle. Earthquakes in south-central Alaska are being recorded by a regional network of 51 seismograph stations extending from Yakutat through Prince William Sound, the Chugach Mountains and Cook Inlet, to the Katmai National Monument. Data from the network, as well as those from the worldwide network of seismographs, are used to locate earthquakes in the active seismic zone of southern Alaska and the Gulf of Alaska. The seismic studies are complemented by measurements of crustal deformation undertaken in cooperation with other studies.

Product:

Page, R. A., 1975, Evaluation of seismicity and earthquake shaking at offshore sites: Offshore Technology Conf., 7th, Houston, Texas, 1975, Proc., v. 3, p. 179-190.

Title: Central California Seismicity Studies (IV-3)

Status: Ongoing FY 76

Location: California

Principal Contact: CA-3

Objective: To construct models of the earthquake-generating process that will assist in predicting earthquakes in central California; to identify and delineate active faults in central California; to find methods of assessing the potential of these faults for producing a damaging earthquake; and to provide catalogs and computer listings of the locations, depths, origin times, and magnitudes of earthquakes in central California.

\section{Products:}

Bufe, C. G., Pfluke, J. H., and Wesson, R. L., 1974, Premonitory vertical migration of microearthquakes in central California-evidence of dilatancy biasing: Geophys. Research Letters, v. 1, no. 5, p. 221-224.

Steppe, J. A., Bakun, W. H., and Bufe, C. G., 1975, Time-varying p-velocity anisotropy along the San Andreas fault [abs.]: EOS, v. 56, no. 6. p. 399.

Title: Crustal Strain (IV-4)

Status: Ongoing FY 76

Location: California

Principal Contact: CA-3

Objective: To measure slip and elastic strain accumulation along faults and to seek premonitory deformation that might be useful for earthquake prediction. This project involves the measurement of crustal deformation near active faults by means of precise geodetic techniques such as geodimeter surveys for horizontal deformation and level surveys for verProducts: tical movement.

Castle, R. O., Alt, J. N., Savage, J. C., and Balazs, E. I., 1974, Elevation changes preceding the San Fernando earthquake of February 9, 1971: Geology, v. 2, no. 2, p. 61-66. 
Prescott, W. H., and Savage, J. C., 1974, Absence of observable deformation on the Sargent Fault, California, 1970-1973: Geol. Soc. America, Abs. with Programs, v. 6, no. 3 , p. 307 .

Savage, J. C., 1974a, A possible bias in the California State geodimeter data [Abs.] : EOS, v. 56, p. 1191.

1974, The California geodimeter network: measuring movement along the San Andreas fault [abs.]: Earthquake Information Bull., v. 6, no. 3, p. 3 .

- 1975a, A possible bias in the California State geodimeter data: Jour. Geophysical Research, v. 80 , p. 4078-4088.

1975b, Crustal movement investigations: Rev. Geophys. Space Physics, v. 13, p. $263-265$.

1975c, Evidence for afterslip on the San Fernando fault: Seismol. Soc. America Bull., v. 65, p. 829-834.

Savage, J. C., and Prescott, W. H., 1974, Geodimeter measurements of slip and strain accumulation along the San Andreas fault: Tectonophysics, v. 23, p. $407-418$.

\section{Title: San Francisco Bay Region Earthquake Hazard Reduction (IV-5)}

Status: Completed FY 75

Location: California

Principal Contact: CA-3

Objective: To determine the geologic parameters that control seismic amplification. The main focus of the project was to determine the $S$ - wave velocities and the bulk densities of the various geologic units in the southern San Francisco Bay region as a prototype example of this phenomenon. Eighteen 30-metre holes were drilled and logged in 6 different unconsolidated alluvial units and 12 semiconsolidated to well-indurated bedrock units. The seismic velocities and physical properties of each unit were determined.

\section{Title: Earthquake Hazards Reduction, Central Ventura County (IV-6)}

Status: Ongoing FY 76

Location: California

Principal Contact: CA-3

Objective: To review and synthesize existing historic, seismic, geologic, geodetic, and marine geophysical records of all faults in central Ventura County having known or suspected late Quaternary earthquake activity. Satellite and high-altitude $(1: 90,000$ to $1: 250,000$ scale) photography and other imagery are analyzed for linear and other structural features that appear to reflect late Quaternary tectonic activity. Known or suspected young faults are examined by intermediate-scale aerial photographs and by techniques such as trenching, drilling, geophysical surveys, seismic and geodetic networks, and hydrologic and marine geophysical studies. These data are used to determine the length and width of each active fault, the distribution and nature of adjacent landslides, and the character, rate, and chronology of past displacements.

Title: Earthquake Hazards Reduction, Los Angeles Region (IV-7)

Status: Completed FY 75

Location: California

Principal Contact: CA-3 
Objective: To review and synthesize existing historic, seismic, geologic, geodetic, and marine geophysical records of all faults having known or suspected late Quaternary activity. Satellite, high-altitude, and intermediatescale imagery was used to recognize linear and other structural features that appeared to reflect late Quaternary tectonic activity; known or suspected active faults were studied by trenching, drilling, and geophysical studies; the distribution and nature of active faults and adjacent landslides were determined from the chronology of past displacements and the late Quaternary stratigraphic and geomorphic record.

Title: Earthquake Hazard Reduction, San Francisco Bay Region (IV-8)

Status: Completed FY 75

Location: California

Principal Contact: CA-3

Objective: To provide the basic geologic framework for the San Francisco Bay region. Seismic ground response, liquefaction, active faults, and slope stability were studied.

Products :

Clark, J. C., Dibblee, T. W., Jr., Greene, H. G., and Bowen, O. E., Jr., 1974, Preliminary geologic map of the Monterey and Seaside $7.5^{\prime}$ quadrangles, Monterey County, California with emphasis on active faults: U.S. Geol. Survey Misc. Field Studies Map MF-577, scale 1:24,000.

Dupre, W. R., 1975, Maps showing geology and liquefaction potential of Quaternary deposits in Santa Cruz County, California: U.S. Geol. Survey Misc. Field Studies, Map MF-648, scale 1:62,5.00.

Hall, N. T., Sarna-Wojcicki, A. J., and Dupre, W. R., 1975, Faults and their potential hazards in Santa Cruz County, California: U.S. Geol. Survey Misc. Field Studies Map MF-625, scale 1:62,500.

Title: Earthquake Hazard Reduction, San Francisco Bay Region-B, Faults and Fault Activity (IV-9)

Status: Completed FY 75

Location: California

Principal Contact: CA-3

Objective: To identify, characterize, and map the earthquake hazards of the San Francisco Bay region; to develop criteria for recognizing geologic materials subject to landsliding, liquefaction, and other ground failures resulting from erthquakes; and to refine the techniques of estimating ground response to earthquakes for different geologic settings and seismic base motions. Various maps and reports to be used by planners and others concerned with earthquake hazards in the San Francisco Bay region were prepared.

Title: Earthquake Hazards Reduction, Southwestern Ventura County (IV-10) Status: Completed FY 75

Location: California

Principal Contact: CA-3

Objective: To map Quaternary stratigraphic units in the Oxnard Plain and adjacent foothills by using stratigraphic, geomorphic, and soil development criteria; to correlate Quaternary deposits by means of chemical tephrochronology; to map Quaternary faults and compile existing data on surface and subsurface geology, structure, and geophysical data; to 
date Quaternary faults by using relative and absolute age (radiocarbon and amino-acid racimization) data; and to map landslides in the foothills surrounding the Oxnard Plain.

Title: Engineering Seismology (IV-11)

Status: Ongoing FY 76

Location: California

Principal Contact: CA-3

Objective: To develop sound methods for predicting strong earthquake ground motion and ground deformation in terms useful for the design of structures, the writing of codes, and the planning of land use. A secondary goal is to demonstrate how these methods can be applied on a regional basis for seismic hazard zonation, the San Francisco Bay region being used as a test case. Activities include analysis of existing strong-motion data; development of numerical methods for predicting site response under conditions of nonlinear soil deformation; determination of the depth to bedrock by means of seismic field surveys; and seismic measurements to determine the elastic properties of surficial materials.

Title: Fault Zone Tectonics (IV-12)

Status: Ongoing FY 76

Location: California

Principal Contact: CA-3

Objective: To measure tectonic processes in fault zones, to develop a useful theory concerning the mechanics of such processes, and to seek evidence of fault zone activity that might be useful for earthquake prediction or for modification of fault zone behavior. This project involves measurement of fault slip in the form of aseismic creep and other processes and related phenomena, including nearfield strain response during both loading and failure intervals. Results will be interpreted, and theoretical investiProduct: gations related to fault creep will also be made.

Savage, J. C., Burford, R. O., and Kinoshita, W. T., 1975, Earth movements from geodetic measurements, in Oakshott, G. B., ed., San Fernando, California, earthquake of February 9, 1971: California Div. Mines and Geology Bull. 196, p. 174-186.

Title: Instrumental Strain (IV-13)

Status: Ongoing FY 76

Location: California

Principal Contact: CA-3

Objective: To determine the nearfield modes of strain accumulation and release associated with earthquakes on active faults in the Western United States. These studies are necessary for understanding and predicting earthquakes. Instruments in use or being installed at present include 50 tiltmeters, 12 strainmeters, and 7 magnetometers installed along 80 kilometers of the most active section of the San Andreas fault; portable differential magnetometers are in use at 120 sites along more than 1,200 kilometres of the major faults in California and Nevada.

\section{Products :}

Byerlee, J. D., and Johnston, M. J. S., 1974, A magnetic method for determining the approximate size and orientation of hydraulic fractures [abs.]: EOS, v. 55, p. 1193. 
Johnston, M. J. S., 1974a, Tectonomagnetic effects in progress, in Nagata Conference on Magnetic Fields: Pittsburgh, Pa., Univ. Pittsburgh, p. 283-303.

- 1974b, Tectonomagnetic experiments in western U.S.A. [abs.] : EOS, v. 55, p. 1113.

Johnston, M. J. S., Bakun, W. H., Pakiser, L. C., and Tarr, A. C., 1974, Earthquakes can they be predicted or controlled?: Industrial Research, v. 16, p. 31-37.

Johnston, M. J. S., and Mortensen, C. E., 1974, Tilt precursors before earthquakes on the San Andreas fault, California: Science, v. 186, p. 10211034.

Johnston, M. J. S., Mortenson, C. E., Smith, B. E., and others, 1974, Tiltmeter, magnetometer and strainmeter arrays in California installation and some preliminary results [abs.]: EOS, v. 55, no. 4, p. 427.

Johnston, M. J. S., Mortensen, C. E., Smith, B. F., and Stuart, W. D., 1975, Summary and implication of simultaneous observation of tilt and changes in local magnetic field prior to a magnitude 5.2 earthquake near Hollister, California [abs.] : EOS, v. 56, p. 40.

Johnston, M. J. S., Myren, G. D., O'Hara, N. W., and Rogers, J. H., 1975, A possible seismomagnetic observation on the Garlock fault, California: Seismol. Soc. America Bull., v. 65, p. 1114-1119.

Johnston, M. J. S., and Stuart W. D., 1974, The form of pre- and post-earthquake crustal deformation for moderate earthquakes on the San Andreas fault [abs.]: EOS, v. 55, p. 1196.

Jones, Alan C., and Johnston, M. J. S., 1974, Earth strain measurements near the San Andreas fault, California [abs.]: EOS, v. 55, p. 1191.

McHugh, S., Johnston, M. J. S., and Burford, R. O., 1974, Preliminary results on the relation between surface tilt near the San Andreas fault [abs.]: EOS, v. 55, p. 1191.

Mortensen, C. E., and Johnston, M. J. S., 1975, The nature of surface tilt along $85 \mathrm{~km}$ of the San Andreas fault-preliminary results from a 14instrument array: Pure Applied Geophysics, v. 75, p. 237-249.

O'Hara, N. W., and Johnston, M. J. S., 1975, A tectonomagnetic study along the Garlock fault, California [abs.]: Geol. Soc. America Abs. with Programs, v. 7 , no. 7 , p. 12.17 .

Raleigh, C. B., and Johnston, M. J. S., An elastic relaxation of earthquake induced tilts in central California [abs.]: EOS, v. 55, p. 1192.

Smith, B. E., Johnston, M. J. S., and Myren, G. D., 1974, Results from a differential magnetometer array along the San Andreas fault in central California [abs.] : EOS, v. 55, p. 1113.

Stuart, W. D., and Johnston, M. J. S., 1974, Tectonic implications of anomalous tilt before central California earthquakes [abs.]: EOS, v. 55, p. 1197.

1975, Intrusive origin of the Matsushiro earthquake swarm: Geology, v. 3 , no. 2 , p. $63-67$.

Title: San Andreas Earthquake (IV-14)

Status: Ongoing FY 76

Location: California

Principal Contact: CA-3

Objective: To coordinate the development of equipment by private industry, to determine field techniques for measuring gravity changes to the 
highest accuracy possible, and to test the feasibility of developing a capability for mapping gravity changes over a significant region, such as the San Andreas fault. Continuous measurements are being made at selected points within the region and telemetered into a central recording facility in Menlo Park, California.

Products:

Oliver, H. W., Robbins, S. L., Grannell, R. B., Alewine, R. W., and Biehler, Shawn, 1975, Surface and subsurface movements determined by remeasuring gravity, in Oakshott, G. B. ed., San Fernando, California earthquake of February 9, 1971: California Div. Mines and Geology Bull. 196, p. 195-211.

Oliver, H. W., Wood, M. D., and Robbins, S. L., 1974, Evidence from gravity measurements for deformation during and after the San Fernando earthquake of February 9, 1971 [abs.]: EOS, v. 55, no. 4, p. 426.

Robbins, S. L., Oliver, H. W., Holden, K. D., and Farewell, R. C., 1974, Principal facts, accuracies, and sources for 3046 gravity stations on the San Jose $1^{\circ} \times 2^{\circ}$ quadrangle, California: U.S. Dept. Commerce, Natl. Tech. Inf. Service PB-232 728/AS, $106 \mathrm{p}$.

Title: Southern California Microearthquake Network (IV-15)

Status: Ongoing FY 76

Location: California

Principal Contact: CA-3

Objective: To study the seismicity of southern California in cooperation with the California Institute of Technology (Caltech). The project involves the installation, operation, maintenance, and systematic analysis of the southern California microearthquake net as distinct from the regional net operated by Caltech. Data from the network are available to both Geological Survey and Caltech researchers as well as to other institutions and researchers. Existing networks include the Imperial Valley net (20 stations), the Mojave net (22 stations), the San Bernardino net (32 stations), and the Los Angeles Basin net (8 stations).

\section{Title: Hawaiian Volcano Observatory (IV-16)}

Status: Ongoing FY 76

Location: Hawaii

Principal Contact: CA-3

Objective: To provide warnings of impending eruptions and technical advice regarding volcano and related hazards. The eruptions of Kilauea and Mauna Loa Volcanoes are studied in detail; eruptive phenomena are documented photographically, eruptive products are sampled, and vents and flows are mapped. Seismic activity is monitored continuously by a network of about 37 stations. Deformation of the volcanoes is monitored by periodically reoccupying tilt stations, level lines, and trilateration (geodimeter) networks. Additional geophysical methods include resistivity, electromagnetic, magnetic, and gravity studies. Hypotheses of magmatic history and evolution are developed from petrographic and chemical investigations of lava samples. The Hawaiian Volcano Observatory's geologic, geophysical, and geochemical studies contribute to an improved understanding of volcanic processes and to better forecasting techniques. 


\section{Products:}

Tilling, R. I., 1975a, Review of "The making of the earth: volcanoes and continental drift" (by Haroun Tazieff) : Am. Scientist, v. 63, no. 6, p. 701702.

1975b, The Hawaiian Volcano Observatory: Babysitting Kilauea and Mauna Loa two of the world's most active volcanoes: Kilauea Times, June 23-Sept. 7, 1975, p. 4.

Tilling, R. I., Holcomb, R. T., Lockwood, J. P., and Peterson, D. W., 1975, Recent eruptions of Hawaiian volcanoes and evolution of basaltic landforms: Internat. Colloquium Planetary Geology, Rome, Italy, Sept. 2230, 1975, Program, p. 149-152.

Tilling, R. I., Koyanagi, R. Y., and Holcomb, R. T., 1975, Rockfall seismicity -correlation with field observations, Makaopuhi Crater, Kilauea Volçano, Hawaii: U.S. Geol. Survey Jour. Research, v. 3, no. 3, p. 345-361.

Title: Charleston Earthquake Regional Geophysical Studies (IV-17)

Status: Ongoing FY 76

Location: South Carolina and Georgia

Principal Contact: NR-7

Objective: To determine if a unique structure is present in the epicentral area and to understand the tectonics of South Carolina, Georgia, and Florida. Detailed aeromagnetic and refraction and reflection seismic surveys spaced by 1.6 kilometres ( 1 mile) are being used to define Coastal Plain and crystalline basement lithology and structure. This project is part of a cooperative study with the Nuclear Regulatory Commission using geology, geophysics, and earthquake seismology to investigate the possible causes of recurring earthquakes in the Charleston area of South Carolina.

Products:

Higgins, B. B., and Popenoe, Peter, 1974, A geologic and geophysical study of the Charleston, South Carolina, earthquake zone: Earthquake Inf. Bull. v. 6, no. 6, p. 16-23.

Popenoe, Peter, 1975a, Geophysical studies in the Charleston area of South Carolina [abs.] : Am. Soc. Photogrammetry, 41st Ann. Convention, Washington, D.C., Programs, p. 659.

- 1975b, The Charleston earthquake-the search for a geologic causenew magnetic and gravity data [abs.]: Geol. Soc. America, Abs. with Programs, v. 7, no. 4, p. 524.

Zeitz, Ișidore, Higgins, M. W., Popenoe, Peter, and Higgins, Brenda, 1975, Geophysical surveys of the southeastern coastal plain, part II: Preliminary geologic interpretation of new aeromagnetic maps of part of the coastal plain of North Carolina, South Carolina, and Georgia [abs.]: Geol. Soc. America, Abs. with Programs, v. 7, no. 7, p. 1327.

Title: Charleston Geoelectric Studies (IV-18)

Status: Ongoing FY 76

Location: South Carolina

Principal Contact: NR-7

Objective: To identify and delineate basement tectonic structures that may be related to the anomalously high earthquake activity of the CharlestonSummerville area; to establish baseline electric, magnetic, and geodetic datums for future monitoring and checking of the applicability of dilatancy earthquake source models in this area; and to trace resistivity 
structures within the surficial sediments that may be of geological and hydrological significance.

Title: Geologic Investigation of the Charleston, South Carolina, Earthquake Area (IV-19)

Status: Ongoing FY 76

Location: South Carolina

Principal Contact: NR-7

Objective: To investigate the cause of the Charleston earthquake of 1886 . The two-part study examines the basement beneath the Coastal Plain and the deformation within the Coastal Plain secions as an indicator of the probable earthquake cause. Both geologic and geophysical methods are applied within the epicentral areas of the 1886 earthquake.

\section{V.-ENGINEERING GEOLOGY}

Engineering geology studies apply geologic knowledge to civilengineering decisions and practices to assist in man's modification of his natural physical environment. Geological Survey objectives are to provide engineering geology information by means of field and laboratory research and to provide technical assistance and services to other governmental agencies.

Engineering geology investigations in coastal regions are essential to ensure the safety of onshore and offshore structures. Topical studies on subjects such as the strength of materials, the availability and physical properties of rocks and sediments, and the distribution of various physical properties bear directly on the stability of engineered structures. Potentially catastrophic phenomena such as faulting, subaerial and submarine landslides and mudflows, subsidence of the ground surface, differential settlement, lateral spreading, liquefaction, differential erosion, and induced instability owing to changing load are all subjects for engineering geology studies. The potential for the occurrence of these phenomena affects the siting of such structures as drilling rigs, pipelines, port facilities, dwellings, transportation routes, energy transmission corridors, and population and service centers both on land and in the water.

Examples of areas where engineering geology studies have contributed to the knowledge of earth-science constraints on development in coastal zones include: the southern California borderland (recency of faulting, reaction of earth materials to seismic shaking, and construction material resources) ; the San Francisco Bay area (construction material resources, liquefaction, stability of bay muds, reaction of earth materials to seismic shaking, and slope stability); the Puget Sound area of Washington, (slope stability, volcano hazards, excavatability, and construction found- 
ation conditions); and the Alaskan coastal communities, (reconstruction and safe siting of population centers following the Alaska earthquake of 1964).

\section{RELATED ACTIVITIES}

Title: Greater Anchorage Area Borough, Alaska (V-1)

Status: Ongoing FY 76

Location: Alaska

Principal Contact: CA-3

Objective: To investigate geologic and hydrologic processes relevant to regional planning. As a consequence of the effects of the Alaska earthquake of 1964 and its impact on land development, a general geologic map of the Greater Anchorage Area Borough at a scale of 1:63,360 has been prepared and is now in the final stages of compilation. Study of Quaternary deposits is emphasized because most development is concentrated on these deposits. Special-purpose maps concerning slope stability, construction materials, and foundation and excavation conditions are being prepared for use by planners and developers.

Product:

Dobrovolny, Ernest, and Schmoll, H. R., 1974, Slope-stability map of Anchorage and vicinity, Alaska: U.S. Geol. Survey Misc. Inv. Ser. Map I-787-E, scale $1: 24,000$.

Title: Environmental Geology of the San Francisco Bay Region, Slope Stability (V-2)

Status: Ongoing FY 76

Location: California

Principal Contact: CA-3

Objective: To determine the nature, geographic distribution, and economic impact of landslides in the San Francisco Bay region. A landslide inventory was prepared. Selected areas were mapped to determine the regional factors involved in the formation of landslides, and studies were

Products : conducted to examine the relation of topography to slope stability.

Clark, J. C., Dibblee, T. W., Jr., Greene, H. G., and Bowen, O. E., Jr., 1974, Preliminary geologic map of the Monterey and Seaside 7.5-minute quadrangles, Monterey County, California, with emphasis on active faults: U.S. Geol. Survey Misc. Field Studies, Map MF-577, scale 1:24,000.

Dupre, W. R., 1975, Maps showing geology and liquefaction potential of Quaternary deposits in Santa Cruz County, California: U.S. Geol. Survey Misc. Field Studies Map MF-648, scale 1:62,500.

Hall, N. T., Sarna-Wojcicki, A. J., and Dupre, W. R., 1974, Faults and their potential hazards in Santa Cruz County, California: U.S. Geol. Survey Misc. Field Studies Map MF-626, scale 1:62,500.

Sarna-Wojcicki, A. J., Pampeyan, E. H., and Hall, N. T., 1975, Map showing recently active breaks along the San Andreas fault between the central Santa Cruz Mountains and the northern Gabilan Range, California: U.S. Geol. Survey Misc. Field Studies Map MF-650, 2 sheets, scale $1: 24,000$. 
Title: Geologic and Engineering Character of Hillside Materials, Environmental Geology of San Francisco Bay Region (V-3)

Status: Ongoing FY 76

Location: California

Principal Contact: CA-3

Objective: To describe the geologic and engineering character of semiindurated to hard bedrock and weathering products underlying the hillside terraces of the San Francisco Bay region and to determine the relationship between the character of these materials and their topography. Together, these factors have a major bearing on the stability of natural and artificial slopes and therefore on the feasibility of residential and other development of the terrane. Other aspects of the study involved reconnaissance observations of geologic character, measurements of geologic properties and their engineering characteristics and interrelationships, examination and description of 300 mapped geologic formations, and compilation of a 1:125,000-scale map of materials units.

Title: Geologic Environmental Maps for Land Use Planning-Coastal California $(V-4)$

Status: Ongoing FY 76

Location: California

Principal Contact: CA-3

Objective: To prepare small-scale 1:250,000 maps of coastal California on behalf of the Nuclear Regulatory Commission showing major components of the geologic environment that are useful in land-use planning and that may be critical for siting nuclear reactors. Emphasis is placed on faults and the recency of their displacement, large landslides, ground subsidence, and engineering properties of rock and sediment units. Graphic and conceptual techniques that depict in map form the recency of fault displacement have been used in a pilot geologic-environmental map of the greater Los Angeles area. The study includes the recency of faulting in coastal southern California.

Products:

Hall, C. A., Jr., and Prior, S. W., 1975, Geologic map of the Cayucos-San Luis Obispo region, San Luis Obispo County, California; U.S. Geol. Survey Misc. Field Studies Map MF-686, 2 sheets, scale 1:24,000.

Nichols, D. R., and Buchanan-Banks, J. M., 1974, Reducing seismic hazards through land-use planning: U.S. Geol. Survey Earthquake Inf. Bull., v. 5 , no. 6 , p. $3-9$.

Pampeyan, E. H., 1975, Geologic map of the San Andreas fault zone in San Andreas Lake, San Mateo County, California: U.S. Geol. Survey Misc. Field Studies Map MF-652, scale 1:6,000.

Sarna-Wojcicki, A. M., Pampeyan, E. H., and Hall, N. T., 1975, Map showing recently active breaks along the San Andreas fault between the central Santa Cruz Mountains and the northern Gabilan Range, California: U.S. Geol. Survey Misc. Field Map MF-650, 2 sheets, scale 1:24,000.

Title: Geology of the Point Dume Quadrangle and the Los Angeles County Part of the Triunfo Pass Quadrangle, Los Angeles County Cooperative, California (V-5)

Status: Ongoing FY 76

Location: California 
Principal Contact: CA-3

Objective: To map the densely urbanized portion of the Santa Monica Mountains, where slope stability is a major concern. About 70 percent of the area slopes at $26^{\circ}$ or more. General-purpose geologic maps produced at a scale of $1: 12,000$ will emphasize the identification and evaluation of potential geologic hazards. Landslide classification and characterization will be made on slope maps at a scale of 1:24,000. Geologic maps produced at a scale of 1:24,000 will, when they are combined with those of adjoining areas, form the basis for a comprehensive report on the geology of the central Santa Monica Mountains.

Products:

Campbell, R. H., 1974, Debris flows originating from soil slips during rainstorms in southern California: Quart. Jour. Eng. Geology, v. 7, p. 217-218. - 1975, Soil slips, debris flows, and rainstorms in the Santa Monica Mountains and vicinity, southern California: U.S. Geol. Survey Prof. Paper 851, $51 \mathrm{p}$.

Campbell, R. H., Wolf, S. C., Hunter, R. E., Lee, W. H. K., Ellsworth, W. L., Wagner, H. C., Vedder, J. G., and Junger, Arne; 1975, The Santa Barbara Channel region, a review [abs.]: Geol. Soc. America, Abs. with Programs, v. 7 , no. 3 , p. 301-302.

Morton, D. M., and Campbell, R. H., 1974, Spring mudflows at Wrightwood, southern California: Quart. Jour. Eng. Geology, v. 7, p. 377-384.

Wright, R. H., Campbell, R H., and Nilsen, T. H., 1975, Preparation and use of isopleth maps of landslide deposits; reply [to comment by John D. Vitek]: Geology, v. 3, no. 4, p. 217-218.

Title: Pacific Palisades Landslide Area, Los Angeles, California (V-6)

Status: Ongoing FY 76

Location: California

Principal Contact: CA-3

Objective: To study landslides in the Pacific Palisades area of the City of Los Angeles in cooperation with the U.S. Army Corps of Engineers.

Title: Soil Engineering Research (V-7)

Status: Ongoing FY 76

Location: California

Principal Contact: CA-3

Objective: To investigate the application of soil engineering principles and methods to problems in engineering geology. Emphasis is placed on the potential hazards associated with unconsolidated sediments, specifically, seismic ground amplification, liquefaction susceptibility of granular deposits, static and seismic stability of slopes and dikes, total and differential settlement from overburden fills, and subsidence from groundwater extraction. The project also supports regional engineering geology and environmental geology studies to determine engineering classification and the in-place properties of unconsolidated earth deposits, to correlate these properties with geologic variables, and to interpret their significance for land-use planning and engineering purposes. Current emphasis is placed on the unconsolidated deposits and residual soils in the San Francisco Bay region. 
Products:

Yerkes, R. F., Bonilla, M. G., Youd, T. L., and Sims, J. D., 1974, Geologic environment of the Van Norman Reservoirs area: U.S. Geol. Survey. Circ. 691-A, p. A1-A35.

Yerkes, R. F., Youd, T. L., and Alt, N. J. N., 1974, Deformation of the Van Norman Reservoirs area, northern San Fernando Valley, California: Fifth World Conf. Earthquake Eng., 5th, Rome, 1973, Proc., v. 2, p. 2371-2380.

Youd, T. L., 1975, Liquefaction, flow and associated ground failure: U.S. Nat. Conf. Earthquake Eng. 1975, Proc., p. 146-155.

Title: Engineering Geology of Metropolitan Boston, Massachusetts (V-8)

Status: Ongoing FY 76

Location: Massachusetts

Principal Contact: NR-7

Objective: To prepare a series of maps aimed primarily at assisting city planners and engineers. These products include subsurface maps at a scale of 1:6,000 of buried bedrock surface and principal Quaternary sedimentary units beneath Boston and parts of adjoining Cambridge and Brookline; standard 1:24,000-scale maps of the surficial geology of six greater Boston quadrangles emphasizing subsurface and engineering data; a map of the submarine geology of Boston Harbor compiled by using sonar surveys; and a description of the geology of Boston, primarily as revealed by studies of construction excavations and in more than 25,000 foundation borings.

Title: Sea-Cliff Erosion Studies, Massachusetts (V-9)

Status: Ongoing FY 75

Location: Massachusetts

Principal Contact: NR-7

Objective: To study the erosion of sea cliffs on Martha's Vineyard and in Boston Harbor and intertidal rock erosion at Nahant, Massachusetts. The many factors controlling the erosion necessitated an understanding of the geology of the cliffs. The work was extended, and, in consequence, the geology of Martha's Vineyard was studied in detail.

\section{VI.-GEOCHEMICAL AND GEOPHYSICAL STUDIES}

Studies of geochemical processes conducted by the Geological Survey have both hydrologic and geologic components. The basic objective of hydrologically oriented geochemical studies is to understand the chemical reactions between water and earth materials. Most of the known chemical elements have been identified in oceans, rivers, lakes, and ground water. Mineral-water reactions commonly take place over many years in ground-water systems, but rapid chemical changes may occur in surface waters, especially during floods. In addition to dissolved solids, gases such as carbon dioxide and methane may also become entrained and mixed with water and thereby further alter the water quality. 
Geochemical field surveys have been used to assist water managers in the evaluation of complex hydrologic systems. For example, the general pattern of water movement among the recharge areas of central Florida, the underlying aquifer system, and the discharge of fresh ground water from submarine springs have been documented by geochemical and geophysical techniques. Studies are currently underway to evaluate the effects of pumping highly treated sewage into aquifers as a means of restoring water to ground-water reservoirs. The chemical reactions of mixing treated effluent with native ground water may result in the unintentional precipitation of solids. This precipitation, in turn, may lead to a sharp decrease in the ability of the aquifer to transmit water to wells. Laboratory experiments are currently being conducted to determine the effect on the chemical quality of water percolation through unsaturated soils above aquifers.

The use of geochemical techniques in determining the time required for ground water to reach a particular site in an aquifer is currently being evaluated. This information is of considerable value in estimating the probable hazards that nuclear wastes injected upgradient will pose at any selected pumping site.

Extensive studies are being conducted in estuarine and marine environments to define the processes that control water and sediment chemistry. These studies focus on trace metals introduced into surface waters as a result of man's activities. The purpose of this research is to enable managers to predict the movement, distribution, and fate of these potentially toxic substances in estuarine environments.

The products of hydrologically oriented geochemical studies range from reports on highly technical aspects of specific reaction processes, both in the field and in the laboratory, to maps at various scales portraying the areal distribution of various chemical constitutents in aquifers, lakes, or watercourses. The reports may summarize the impact of waste disposal on the return of water by injection wells at a particular site. They may be oriented to a particular estuarine environment such as San Francisco Bay, where several geochemical projects are currently underway in conjunction with a large comprehensive study of the bay's environment.

Geologically oriented studies are establishing geochemical baselines (datums and standards) on the distribution of elements in rocks, soils, and vegetation. The baselines are needed and used for measuring and predicting chemical and physical changes in the environment, and this program will form the foundation for a 
national geochemical survey. Future decisions on pollution control and environmental health will use the baselines established through the geochemical sampling activities.

Geochemical baselines are the result of combined fieid and laboratory studies. In the field, the major objective is the development of a practical national statistical approach to geochemical sampling. Laboratory research is directed toward compilation of worldwide geochemical data from the literature and toward improving chemical analytical techniques and management of the data base.

The isotope geology studies investigate, develop, and use methods for determining ages of rocks and minerals, and apply geochemical methods to mineral exploration. These objectives serve basic data needs for understanding the Earth's history and the geologic processes of the past and present.

The objective of geophysical studies is to develop tools, techniques, and concepts for the various geophysical activities in the energy and mineral fields, in the volcano and earthquake hazards programs, and in environmental and engineering geology. The objectives of these studies are to interpret the geophysical force fields associated with different rocks and structures and to investigate the behavior of the Earth's past and present magnetic fields: Ongoing studies include gravity and magnetics, electrical and electromagnetic research, seismicity, heat-flow investigations, and the physical properties of rocks at high temperatures and pressures.

Techniques are being investigated for measuring the polarity reversal of the Earth's magnetic field, for determining crustal plate movement, for measuring the electrical conductivity of the Earth's crust, and for making global magnetic measurements from space.

\section{RELATED ACTIVITIES}

Title: Distribution of Elements in the Fluvial and Brackish Environments (VI-1)

Status: Ongoing FY 76

Location: Nationwide

Principal Contact: NR-1

Objective: To detect changes in the chemistry of water and sediments in selected environments.

Products:

Jones, B. F., Kennedy, V. C., and Zellweger, G. W., 1974, Comparison of observed and calculated concentrations of dissolved $\mathrm{Al}$ and $\mathrm{Fe}$ in stream water: Water Resources Research, v. 10, no. 4., p. 791-793. 
Kennedy, V. C., Zellweger, G. W., and Jones, B. F., 1974, Filter pore-size effects on the analysis of $\mathrm{Al}, \mathrm{Fe}, \mathrm{Mn}$, and $\mathrm{Ti}$ in water: Water Resources Research, v. 10, no. 4, p. 785-790.

\section{Title: Quaternary Dating Techniques (VI-2)}

Status: Ongoing FY 76

Location: Nationwide

Principal Contact: $\mathrm{CO}-1$

Objective: To provide basic information on Quaternary dating techniques and time stratigraphies. A major part of this project involves reviewing current dating techniques and local time stratigraphies for continued updating of the program and recommending areas of new research and support. Research goals include studies of weathering, volcanic-ash-bed dating, soil development, and local and regional soil-temperature measurements.

Title: Spatial Distribution of Chemical Constituents in Ground Water (VI-3) Status: Ongoing FY 76

Location: Nationwide

Principal Contact: NR-1

Objective: To assess the chemical and physical changes that occur in an aquifer owing to either the injection of recharge or the withdrawals of water supplies.

Title: Environmental Organic Geochemistry of Outer Continental Shelves (VI-4)

Status: Ongoing FY 76

Location: Maine, New Hampshire, Massachusetts, Connecticut, New York, New Jersey, Delaware, Maryland, Virginia, North Carolina, South Carolina, Georgia, Florida, Alabama, Mississippi,. Louisiana, and Texas

Principal Contact: NR-7

Objective: To determine quantitatively and to distinguish qualitatively the low-level baseline concentrations of naturally occurring organic constituents such as hydrocarbons, asphaltics, fatty acids, sterols, and metalloorganic complexes in surface shelf and slope sediments; to differentiate and classify those naturally occurring organic substances and organometallic complexes that are related to specific geological and geochemical processes, such as major changes in rates of sedimentation, sediment lithification, temperature-redox potential, and lithofacies type; and to develop statistical models for predicting the fate and effects of synthetic chemical and petroleum products on the quality of the marine environment.

\section{Title: Geochemistry of Food Plants (VI-5)}

Status: Ongoing FY 76

Location: New York, New Jersey, Florida, Texas, Michigan, California, and Washington

Principal Contact: CO-1

Objective: To determine typical concentrations of chemical elements in a variety of food plants grown commercially in widely separated areas of the United States, to relate these concentraions to the element content of the soils that support them, and to determine differences in elemental 
composition within each species of food plant as controlled by both internal (genetic) factors and site factors (geologic materials present, soil $\mathrm{pH}$, climate, and so on).

Title: Geochemistry of San Francisco Bay Waters and Sediments (VI-6) Status: Ongoing FY 76

Location: San Francisco Bay, California

Principal Contact: WR-1

Objective: To define the dominant processes that influence water and sediment chemistry in the San Francisco Bay estuarine system.

Title: Pacific States Geophysical Studies (VI-7)

Status: Ongoing FY 76

Location: California

Principal Contact: CA-3

Objective: To collect and interpret gravity and aeromagnetic data over northern California in order to gain a better understanding of regional tectonism and structure. Gravity surveys in the area covered by the Redding 1:250,000-scale map sheet and aeromagnetic surveys over the San Andreas fault and other faults in the San Francisco Bay area are being interpreted for the purpose of environmental applications.

Title: Sierra Nevada Geophysical Investigations and Gravity Changes (VI-8) Status: Ongoing FY 76

Location: California

Principal Contact: CA-3

Objective: To test isostasy in the Sierra Nevada and to determine the mechanism of isostatic compensation; to determine the feasibility of using geophysical methods to locate and trace gold-bearing placer deposits in the northern Sierra Nevada; to increase the accuracy of gravity data in the northern Sierra Nevada; and to increase the accuracy of gravity measurements in order to measure changes associated with tectonic movements.

Products:

Oliver, H. W., Robbins, S. L., Grannell, R. B., Alewine, R. W., and Beihler, Shawn, 1975, Surface and subsurface movements determined by remeasuring gravity, in Oakshott, G. B., ed., San Fernando earthquake of February 9, 1971: California Div. Mines and Geology Bull. 196, p. 195-211.

Oliver, H. W., Wood, H. D., and Robbins, S. L., 1974, Evidence from gravity measurements for deformation during and after the San Fernando earthquake of February 9, 1971 [abs.] : EOS, v. 55, no. 4, p. 426.

Robbins, S. L., Oliver, H. W., Holden, K. D., and Farewell, R. C., 1974, Principal facts, accuracies, and sources for 3,046 gravity stations on the San Jose $1^{\circ} \times 2^{\circ}$ quadrangle, California: U.S. Dept. Commerce Natl. Tech. Inf. Service PB-232 728/AS, 106 p.

\section{VII.-GEOLOGY OF MINERAL OGCURRENCE AND EXPLORATION TECHNOLOGY}

The economy of the Nation is dependent upon annual imports of raw and processed metallic and nonmetallic minerals exceeding $\$ 20$ billion in value in addition to the $\$ 55$ billion worth of minerals produced domestically. The Geological Survey's responsibility 
in discovering domestic mineral resources and identifying their character, economic value, and extractability is therefore more acute than ever because shortages and dependencies cannot be immediately alleviated. The search for new mineral resources is now being accelerated to meet anticipated increases in demand.

Mineral-resource survey studies perform three important functions for government, industry, and the public. They (1) provide basic information and research expertise on the availability of metallic and nonmetallic mineral resources for the purpose of mineral policy decisions; (2) respond to legislative inquiries on energy and mineral policy decisions; and (3) conduct research on a broad spectrum of subjects relevant to mineral resources, using, in the process, expertise rendered by State geological surveys, private foundations, the minerals industry, and other Federal agencies (for example, the Bureau of Mines).

Resource appraisals conducted by the Geological Survey are of three types: (1) general inventories of past production and resource activity, used to identify areas needing more detailed study; (2) reconnaissance-level appraisals to establish resource estimates useful in making decisions on land use and in formulating minerals policies; and (3) detailed geoscience investigations to gain an understanding of the geologic processes that form mineral deposits and to determine the reserves of certain minerals so that management decisions regarding leasing and the environmental consequences of minerals development can be made.

The Alaska Mineral Resource Assessments Program, a 10-year effort that began in 1975 to evaluate Alaska's mineral resources, is an example of this activity. Using geoscience techniques, this program has already succeeded in discovering new mineral deposits and at the same time has systematically mapped the State. Similar concentrated research efforts are underway in mineralized areas of the coastal States of Michigan, Oregon, and Wisconsin.

Another aspect of these activities involves studies of the geology of mineral occurrence that focus on the mechanics of mineralization processes and on the role played by environmental controls in the formation of minerals. Studies are conducted to trace the origin of both high-and low-grade mineral deposits, especially those containing much-needed mineral commodities; to determine the regional control on mineralization; to discover the physiochemical processes governing ore-forming fluids; to develop and use radiometric dating techniques; and to decipher the composition of metallic and nonmetallic deposits. In this manner, data on how minerals form can lead to concepts of how and where deposits 
(for example, orebodies) form, and thus the discovery of minerals on both local and global scales can be expedited.

Many mineral deposits elude detection because their mineral contents are low grade and/or they are too deeply buried. Exploration technology studies are concerned with developing geophysical and geochemical methods of discovering these deposits. Field investigations range from in-place chemical surveys of extremely subtle anomalies in a given area, through sampling stream sediments for trace-metal content, to airborne surveying to detect volatile compounds. Geophysics, particularly aeromagnetic and gravity surveys, coupled with satellite imagery, have also been useful in discovering new deposits in the United States and abroad.

One consequence of these studies is the assembling of a large data base. In order to intelligently interpret the data gathered, computerized information systems have been developed. The objective of this activity is to make mineral-resource data available and interpretable for use in policy decisions. Planning alternatives for mineral development and use can be generated by this process.

Two computer-based information systems are CRIB (Computerized Resource Information Bank) and DORIS (DecisionOriented Resource Information System). CRIB is compiling a file of the world's 1,000 largest mines, which represent 90 percent of the world's supply of 22 major minerals. DORIS consists of mathematical models and analyses of resource system and information on exploration processes, the economics of resource convertibility, and long-term mineral supply and demand.

\section{RELATED ACTIVITIES}

Title: Computerized Resources Information Bank (CRIB) (VII-1)

Status: Ongoing FY 76

Location: Nationwide

Principal Contact: NR-7

Objective: To provide the user, in combination with GIPSY (General Information Processing System), with effective assistance in the organization, manipulation, and display of mineral-resource data. CRIB, the Geological Survey's mineral-resource data file, consists of a set of variable-length records on mineral deposits and commodities of the United States and, to some extent, of the world. CRIB uses GIPSY as the primary file management program to build, store, retrieve, and update records. CRIB can organize and summarize mineral-resource information and can display the results in summary reports, tables, and maps.

Product:

Calkins, J. A., and Dieter, L. E., 1974, Uses of CRIB-A GIPSY-formatted mineral resources computer file [abs.]: Geol. Soc. America Abs. with Programs, v. 6, no. 7, p. 678-679. 
Title: Decision-Oriented Resource Information System (DORIS) (VII-2)

Status: Ongoing FY 76

Location: Nationwide

Principal Contact: NR-7

Objective: To provide substantial and quantitative data concerning mineral resources, derived from the interpretation of data from an information bank, for a specific inquiry or policy decision. Decision-oriented capabilities will be developed in four major fields related to mineral commodities: (1) Geological availability, (2) technological availability, (3) general economic availability, and (4) alternative sources of supply and resources. The system has been designed for three main user groups: Scientists, administrators and policymakers.

Title: High-Resolution Geophysical Data Interpretation (VII-3)

Status: Ongoing FY 76

Location: Federal Outer Continental Shelf lease areas.

Principal Contact: DC-1, LA-2, and CA-2

Objective: To evaluate, shallow high-resolution geophysical data in order to contribute to a detailed environmental assessment of the OCS areas. These data yield information on sea-bottom profiles, areas of unstable bottom conditions, shallow faulting, shallow gas pockets, and gas seeps. Such information is vital for the approval of drilling locations and the placement of drilling and production platforms. Only those data that have been obtained by sole source contract for the Geological Survey are available for inspection at the Gulf of Mexico Regional Office in Metairie, Louisiana.

\section{Title: Continental Offshore Stratigraphic Test (COST) Program (VII-4)}

Status: Ongoing FY 76

Location: Federal Outer Continental Shelf (OCS) lands off the shores of Alaska, California, Texas, New Jersey, and Massachusetts

Principal Contact: DC-1, LA-2, CA-2

Objective: To obtain subsurface geologic information in rrontier OCS areas by means of stratigraphic test wells. At present, two wells, the Gulf of Mexico COST no. 1 and Gulf of Mexico COST no. 2, have been drilled in off shore southern Texas; one well, the Gulf of Alaska COST no. 1, has been drilled in the Gulf of Alaska; another, the COST no. 1, has been drilled in the Outer Banks region of southern California. On the Atlantic OCS, the COST B-2 well in the Baltimore Canyon was completed in March 1976, and the COST G-1 in the Georges Bank area began in spring of 1976. Data from the two Texas wells from the southern California well have been made public. Data from the other test wells will be released 60 days after the issuance of the first Federal lease within 50 geographic miles of the well or 5 years after the completion of the well, whichever comes first.

Title: Peat Studies (VII-5)

Status: Ongoing FY 76

Location: Maryland, New York, Maine, Florida, and North Carolina

Principal Contact: NR-7

Objective: To study peat deposits in 10 areas representing major terrain types typical of the Northeastern United States. Field studies will be 
made of peat suitability as a soil conditioner and for horticultural use. Objectives of the study include discovering physiographic and geologic controls of the occurrence and size of peat deposits; determining the relation of stratigraphy and ecology to water movement and diagensis affecting peat-quality change; and cataloging major deposits according to new American Society for Testing and Materials standards for both current agricultural uses and anticipated uses in the manufacture of foodstuffs and pollution controls. These objectives are aimed at facilitating exploration by private industry and at presenting quantitative data obtained on deposits to assist others in their ground-water, engineering, conservation, land-management, and geochemical-prospecting studies.

Product:

Cameron, C. C., 1975, Some peat deposits in Washington and southeastern Aroostook Counties, Maine: U.S. Geol. Survey Bull. 1317-C, 40 p.

Title: Phosphate in the Southeastern United States (VII-6)

Status: Ongoing FY 76

Location: Florida, Georgia, South Carolina, and North Carolina

Principal Contact: CO-1

Objective: To perform a resource appraisal of the phosphate deposits of the Eastern United States. The goal of the project is to determine the economic geology of the phosphate deposits, including resources, reserves, stratigraphy, structure, mineralogy, chemistry, and, ultimately, the origin of the deposits.

Title: Geology and Mineral Resources of the Ketchikan Quadrangle, Alaska (VII-7)

Status: Ongoing FY 76

Location: Alaska

Principal Contact: CA-3

Objective: To publish a regional 1:250,000-scale geologic map and to assess the mineral resources of the Ketchikan quadrangle. Significant mineral commodities in the project area are molybdenum, gold, silver, copper, lead, zinc, and tungsten. The study includes geologic mapping and surveys by geochemical and geophysical methods.

\section{Title: Nome Investigations (VII-8)}

Status: Ongoing FY 76

Location: Alaska

Principal Contact: $\mathbf{C A - 3}$

Objective: To establish the regional geological controls of all mineral deposits around Nome, Alaska, and to determine their qualitative potential. The approach consists of reconnaissance areal geologic mapping and integrated geochemical surveys and studies of the bedrock of a 5,000square-kilometre (1,930-square-mile) area that includes the most productive gold deposits of the past and those possessing the greatest potential for the future.

Title: Southwestern Alaska (VII-9)

Status: Ongoing FY 76

Location: Alaska

Principal Contact: CA-3 
Objective: To upgrade basic geologic knowledge and to obtain mineral-resource information in the Goodnews Bay and Magemeister Island 1:250,000 -scale quadrangles. The investigations include reconnaissance mapping at the 1:250,000 and 1:63,360 scales and also geochemical, geophysical, and telegeological studies. The study area contains the only domestic platinum mine and several dormant placer-gold mines. It also contains minor indications of mercury, copper, lead, and zinc mineralization.

Title: Tracy Arm-Fords Terror Wilderness Study Area (VII-10)

Status: Ongoing FY 76

Location: Alaska

Principal Contact: CA-3

Objective: To study, in cooperation with the Bureau of Mines, the potential mineral resources of the western flank of the Coast Range batholithic complex. The area is known to contain deposits of copper, lead, silver, zinc, and gold. The study includes reconnaissance geologic mapping, intensive geochemical sampling of bedrock and stream sediments, mapping and sampling of known prospects, and aeromagnetic mapping. The project is part of the U.S. Forest Service study of the suitability of the project area for classification in the National Wilderness System.

Products :

Brew, D. A., 1974, Preliminary results of studies in the Tracy Arm-Fords Terror Wilderness study area, in Carter, Claire, ed., U.S. Geological Survey Alaska Program, 1974: U.S. Geol. Survey Circ. 700, p. 56.

Brew, D. A., Ford, A. B., Grybeck, D., and Nutt, C. J., 1975, Coast range transect in Tracy Arm-Fords Terror Wilderness study area contains seven major belts of rock, in Yount, M. E., ed., U.S. Geological Survey Alaska Program, 1975: U.S. Geol. Survey Circ. 722, p. 53.

\section{Title: Bradwell Bay Wilderness-Sopchoppy Study Area (VII-11)}

Status: Completed FY 75

Location: Florida

Principal Contact: NR-7

Objective: To perform a mineral-resource evaluation of the Bradwell Bay Wilderness-Sopchoppy River study area of Florida in response to the Wilderness Act (Public Law 88-577) by means of reconnaissance geologic mapping and reconnaissance drilling for peat and sand in unconsolidated materials.

Title: Medford-Coos Bay Quadrangles, Oregon (VII-12)

Status: Ongoing FY 76

Location: Oregon

Principal Contact: CA-3

Objective: To prepare a mineral-resource analysis folio of the Medford quadrangle and the southern half of the Coos Bay quadrangle of southwestern Oregon, with primary emphasis on evaluating potential mineral resources and their relation to regional structure, tectostratigraphic units, and present plate-tectonic models; to reinterpret the stratigraphy, structure, and metamorphism of various Paleozoic and Mesozoic units, ultramaficmafic sequences, and granitic intrusive rocks; and to evaluate platinumgroup metal potential in ultramafic rocks and the potential for massive sulfide deposits associated with belts of andesite-rhyolite volcanic rocks. 
Product:

Page, N. J., Johnson, M. G., Haffty, Joseph, and Ramp, Len, 1975, Occurrence of platinum group metals in ultramafic rocks of the Medford-Coos Bay $2^{\circ}$ quadrangles, southwestern Oregon: U.S. Geol. Survey Map MF-694, scale $1: 250,000$.

Title: Southeast Appalachian Sediments (VII-13)

Status: Ongoing FY 76

Location: Virginia

Principal Contact: NR-7

Objective: To map the Pleistocene beach deposits of southeastern Virginia at a scale of 1:250,000 in order to estimate titanium and monazite mineral resources and to produce information that may assist in sand and gravel exploration.

\section{VIII.-MARINE AND ESTUARINE STUDIES}

"An estuary is a semi-enclosed coastal body of water which has free access to the ocean and within which sea water is measurably diluted by fresh water from land drainage" (Pritchard, 1967).

Estuaries are subject to wide variations in their physical, biological, and chemical parameters, both seasonally and spatially. Tides, weather changes, wind-driven currents, and variations in freshwater inflow predispose estuarine ecosystems to rapid shortterm changes in salinity, nutrient content, turbidity, and temperature. Estuarine life forms have evolved to cope with such natural environmental changes, but human activities have imposed additional stresses that may impair or limit the development of a particularly valuable species of estuarine life.

Man-induced stresses on estuarine ecosystems frequently result from increased urbanization. These stresses are manifested in the need for storm-runoff and sewage disposal, improved navigation facilities, expanded water supplies, and increased energy requirements. An evaluation of the hydraulic, chemical, and biotic changes induced by human activities is the primary purpose of the Geological Survey's water-related projects in estuaries. Related studies of estuarine processes are also discussed in the sections entitled "X.--Surface-water studies," "XI.-River-water quality and sedimentation studies," and "III.-Regional geologic and hydrologic surveys, mapping, and analysis."

Studies to evaluate the flow patterns, freshwater-saltwater balances, sediment transport, and ecologic composition of estuaries are currently being conducted by the Geological Survey in Maryland, North Carolina, South Carolina, Florida, Texas, and California. Many of these studies are cooperative efforts with other Federal, State, and local agencies that are attempting to de- 
fine the consequences of planned changes in estuarine water balances. For example, freshwater inflow to the Charleston harbor estuary in South Carolina was greatly increased in 1941 by the diversion of water from the Santee River into the upper Cooper River, which flows into the harbor. This radical change in flow discharge increased the sediment load of the estuary, so that shoaling became a serious problem. To reduce dredging costs, a rediversion canal is planned to reduce runoff to Charleston harbor. The Geological Survey is conducting studies to evaluate the impact of the proposed rediversion on the estuarine environment of Charleston harbor.

Deep-channel dredging of Tampa Bay on the Florida gulf coast to accommodate large ships poses unique problems for local officials. Spoil from the dredging operations, which must be redeposited in the bay itself, create obvious water-quality and ecologic hazards. The Geological Survey has developed a digital flow model of the estuary that is currently being used to define changes in circulation patterns and to help predict how the redepositing of dredged material will affect water quality in the bay.

The impact of waste disposal on estuaries is being studied in the Rhode River estuary, a tributary to the Chesapeake Bay, and in the Duwamish River estuary of Washington. This research is being conducted to evaluate the impact of various methods of waste disposal on the ecology of water adjacent to proposed sewage-treatment plants. These studies are designed to provide State and local officials with the information necessary to protect the delicate ecologic balances of estuaries.

The Geological Survey's marine environment programs have expanded in the past 3 years as the Nation has increased its efforts to become self-sufficient with respect to oil and gas. Marine investigations are in part oriented to support oil and gas resource appraisals in proposed lease areas; environmental studies relating to ocean mining, seabed drilling, and coastal research are also being conducted.

Objectives of the marine environmental investigation studies are: (1) To characterize geologic hazards in the marine environment, namely, earthquakes, faulting, slumping, excessive erosion, and weak foundation strength and (2) to identify sources, pathways, and sinks for contaminants on the ocean floor and their effect on the marine biota. Characterization of the environmental conditions includes regional, geological, geophysical, and sedimentological mapping of the OCS, the establishment of engineering criteria for the sea floor, and the evaluation of the environmental 
consequences of developing offshore oil and gas fields. Information collected in these environmental baseline studies is made available to Federal, State, and local planners and to the public.

Coastal research is being carried out in Maine, Massachusetts, the Chesapeake Bay, Florida, Louisiana, Texas, California, Oregon, and Alaska. A major portion of this work is in the study of coastal geologic processes such as sediment transport, water circulation, and pollutant dispersal. Engineering properties of the sea floor are being investigated, in areas where tectonic events are frequent and where subaqueous sediments are unstable, in order to define the hazards associated with the siting of drilling platforms and pipelines. Other efforts are directed toward the identification and distribution of nonpetroleum resources such as sand and gravel, gold, phosphates, manganese, and heavy minerals by means of geophysical, geochemical, and sedimentological methods.

One of the most important features governing the global climate is the extensive ice cover in the Arctic Ocean. The presence of the arctic icefield not only controls the climate of neighboring land masses but is also of vital importance to weather patterns in the entire Northern Hemisphere. Geological Survey scientists are developing computer models of sea-ice cover to define the impact of this major element of the Earth's heat balance. Data input to the model will be obtained by remote sensing techniques, which offer the best opportunity for obtaining information on sea-ice dynamics.

\section{RELATED ACTIVITIES}

Title: Hydrologic-Oceanographic Interrelations (VIII-1)

Status: Ongoing FY 76

Location: Atlantic and Gulf coasts

Principal Contact: NR-1

Objective: To investigate water circulation patterns in the nearshore coastal waters and in submarine aquifer systems.

Title: New England Coastal Zone (VIII-2)

Status: Ongoing FY 76

Location: Maine, New Hampshire, Connecticut, and New York

Principal Contact: NR-7

Objective: To lend technical and financial assistance to State-supported investigations in New England. During the past several years, this support included a bottom-gravity survey of part of the eastern Gulf of Maine conducted by the University of New Hampshire, high-resolution seismic surveys of the southern part of Lake Champlain made by Middlebury College, and a high-resolution seismic survey of Muscongus Bay, Maine, done in cooperation with the Maine Geological Survey. Presently, the project supports a bedrock mapping program in the western Gulf of 
Maine conducted by the Woods Hole Oceanographic Institution, Woods Hole, Massachusetts.

Title: Natural Resources and Tectonic Features, Gulf of Mexico (VIII-3)

Status: Ongoing FY 76

Location: Florida, Georgia, South Carolina, Alabama, Mississippi, Louisiana, and Texas

Principal Contact: $\mathrm{CO}-1$

Objective: To compile land and marine geological and geophysical data from the Gulf of Mexico region in cooperation with the U.S. Naval Oceanographic Office. Publication of five maps is planned: tectonic, free-air anomaly, Bouguer anomaly, total magnetic field, and residual magnetic field. The principal product will be a tectonic map of the gulf and its adjacent land areas that will summarize the present knowledge of this ocean basin in conventional mapping terms. The map will also extend the land geology into offshore areas. The map series will provide an authoritative base for the appraisal of the gulf's mineral-resource potential.

Title: Environmental Studies in Gulf of Mexico (VIII-4)

Status: Ongoing FY 76

Location: Texas, Louisiana, Mississippi, and Florida

Principal Contact: CO-1

Objective: To study the distribution of trace elements in the Continental Margin transition zone in order to ascertain the spatial and temporal variations of trace elements in the coastal environment and the physiochemical processes that control them. This study includes laboratory and field investigations of partitioning trace elements and the rates by which these elements are introduced and removed from this zone. Particular attention is given to the environmental capacity of these elements-that is, the upper limit of concentration that the environment can effectively absorb without detrimental results.

Products:

Holmes, C. W., 1974, Maps showing distribution of selected elements in surface-bottom sediments of Corpus Christi and Baffin Bays, Texas: U.S. Geol. Survey Misc. Field Studies Map MF-571, 2 sheets.

1975 , Natural versus anthropogenic contributions of trace metals to the sediments on the south Texas Continental Shelf [abs.]: Geol. Soc. America Abs. with Programs, v. 7, no. 7, p. 1119-1120.

Holmes, C. W., Slade, E. A., and McLerran, C. J., 1974, Migration and redistribution of zinc and cadmium in a marine estuarine system: Environmental Sci. and Technology, v. 8, p. 255-259.

McLerran, C. J., and Holmes, C. W., 1974, Deposition of zinc and cadmium by marine bacteria in estuarine sediments: Limnology and Oceanography, v. 19 , no. 6 , p. $998-1001$.

Title: Oil Migration and Diagenesis of Argillaceous Sediments in Gulf of Mexico (VIII-5)

Status: Ongoing FY 76

Location: Texas, Louisiana, Mississippi, Alabama, and Florida

Principal Contact: $\mathrm{CO}-1$ 
Objective: To study pelitic mineral distributions in the sediments of the Gulf coast Continental Shelf and Slope in order to ascertain the spatial and temporal variations of specific clay minerals and to investigate the physiochemical processes that control them. The study is based on both laboratory experimentation and field determination and includes examination of cores from 93 holes drilled in 1966-68 on the Gulf of Mexico Continental Shelf and Slope.

Title: Chalk Reservoir Appraisals (VIII-6)

Status: Ongoing FY 76

Location: Alabama, Texas, and Mississippi

Principal Contact: NR-7

Objective: To study the patterns of diagenesis of chalk under varying temperatures, pressures, loading rates, pore-water chemistries, primary depositional environments, and initial clay contents. The study is designed to predict the porosity and permeability of chalks at various depths, to discover the reasons for anomalously high porosities in chalk-oil reservoirs, to use chalk diagenesis to determine paleodepth of burial and paleogeothermal gradients, and to evaluate the utility of chalk diagenetic alternation gradients for predicting proximity to major sructural and thermal features. Techniques being used include porosity and permeability analysis, carbon and oxygen isotopic analysis, insoluble residues, strontium and magnesium trace-element analysis, scanning electron microscopy, petrographic microscopy, and measurement of vitrinite reflectance. These techniques should facilitate the prediction of oil and gas resources in chalks on the Outer Continental Shelves.

Title: Instability Problems in Delta Front Sediments (VIII-7)

Status: Ongoing FY 76

Location: Louisiana and Texas

Principal Contact: $\mathrm{CO}-1$

Objective: To gather knowledge on bottom instabilities, especially as evidenced around large modern deltas, in cooperation with industry and academic institutions. Investigations are being conducted on the Mississippi Delta into the role of biogenic methane gas in diminishing the inherent strength of a sediment, the influence of storm-wave pressures on nonrigid sea bottoms as a triggering mechanism for slumps, the importance of cementing agents in the formation of the "crusts" that characterize certain delta sediments, and the part played by excess pore-water pressures in localizing instabilities.

Product:

Whelan, Thomas, III, Coleman, J. M., Suhayda, N. J. N., and Garrison, L. E., 1975, The geochemistry of recent Mississippi River Delta sediments: gas concentration and sediment stability: 1975 Offshore Technology Conf. Paper OTC 2342.

Title: Continental Margin Sediment Dynamics (VIII-8)

Status: Ongoing FY 76

Location: California, Oregon, Washington, and Alaska

Principal Contact: CA-3

Objective: To study the mechanisms that induce sediment transport on the Western Continental Margin of the United States. Processes investigated 
include internal waves, wind waves, long surface waves, density currents, wind-driven currents, and tidal currents. Types of transport investigated include both suspended sediment and bedload. This information will increase understanding of the locations and rates of erosion and deposition and the direction and rate of sediment transport.

\section{Title: Geochemistry of San Francisco Bay Waters and Sediments (VIII-9)} Status: Ongoing FY 76

Location: California, Oregon, Washington, and Alaska

Principal Contact: CA-3

Objective: To define the dominant processes that influence water and sediment chemistry in the San Francisco Bay estuarine system and, in certain cases, to evaluate the rates of these processes. Systematic field sampling being done on the physical and chemical properties of the inflow to and water mass within the bay includes tests of the salinity, temperature, and $\mathrm{pH}$ of water and detection and measurement of dissolved oxygen, plant nutrients, and elements associated with suspended particles and bottom sediments. Field observations are being combined with parallel investigations of biotic productivity, benthic population, and water circulation within the estuary.

Products:

Conomos, T. J., and Peterson, D. H., 1974, Biological and chemical aspects of the San Francisco Bay turbidity maximum: Inst. Géologie Bassin d'Aquitaine Mem. no. 7, 15 p.

Peterson, D. H., Conomos, T. J., Broenkow, W. W., and Scrivani, E. P., 1975, Processes controlling the dissolved silica distribution in San Francisco Bay, in Cronin, L. E., ed., Estuarine research, vol. 1, Chemistry, biology, and the esturene system: New York, Academic Press, p. 153-187.

\section{Title: Hydrology of Estuarine Intertidal Environments (VIII-10)}

Status: Ongoing FY 76

Location: Selected estuaries in the Pacific Northwest, Oregon and Washington Principal Contact: OR-1

Objective: To identify the sources of sediments in estuaries and the changes stemming from man's activities and to provide data for predicting natural and man-induced stresses on estuaries.

\section{Title: Pacific Coast Sediments (VIII-11)}

\section{Status: Ongoing FY 76}

Location: California, Oregon, and Washington

Principal Contact: CA-3

Objective: To study depositional processes and facies that occur on and near the open coast along the west coast of the United States in order to compare and evaluate environmental parameters from selected settings and determine their influence on depositional processes. Other goals are to identify and analyze those coastal processes that relate to man's use of the coastal zone; to determine the effect of depositional processes and settings on the accumulation of natural resources; to catalog the sedimentological environments that categorize the west coast; and to compare these parameters with those of other coastal areas. 
Products:

Clifton, H. E., 1975a, Recognition of ancient beaches and beach environments [abs.]: Am. Assoc. Petroleum Geologists and Soc. Econ. Paleontologists and Mineralogists Ann. Mtg., Proc., v. 2, p. 12.

$1975 \mathrm{~b}$, Sedimentary structures produced by shoaling waves [abs.]: Am. Assoc. Petroleum Geologists and Soc. Econ. Paleontologists and Mineralogists Ann. Mtg., Proc. v. 2, p. 12.

Hill, G. W., and Hunter, R. E., 1975, Interaction of biological and geological processes in the beach and nearshore, northern Padre Island, Texas [abs.]: Am. Assoc. Petroleum Geologists and Soc. Econ. Paleontologists and Mineralogists Ann. Mtg., Proc. v. 2, p. 35.

Title: San Francisco Bay (VIII-12)

Status: Ongoing FY 76

Location: California, Oregon, and Washington

Principal Contact: CA-1

Objective: To describe the geological, seismological, biological, geochemical, and hydrographical processes active in the bay region. Specifically, the goals are to describe the geology, tectonic history, seismic environment, and distribution of unconsolidated sediments in the fault-bounded bay basin and the adjacent Continental Shelf; to describe gross water-circulation patterns in the bay and the adjacent Pacific waters in order to understand the movement of natural and man-introduced dissolved and solid constituents; to describe the species composition and areal distribution of major benthic organism communities and establish the absorption rates of trace elements, trace metals, and synthetic organic compounds by benthic organisms, phytoplankton, and marine algae; and to study the distribution of modern bay sediments and the major modes of sediment transport and to evaluate rates of deposition and erosion.

Products:

Conomo, T. J., 1975, Movement of spilled oil as predicted by estuarine nontidal drift: Limnology and Oceanography; v. 20, no. 2, p. 159-173.

Carlson, P. R., and McCollough, D. S., 1974, Aerial observations of suspendedsediment plumes in San Francisco Bay and the adjacent Pacific Ocean: U.S. Geol. Survey Jour. Research, v. 2, no. 5, p. 519-526.

Peterson, D. H., Conomos, T. J., Broenkow, W. W., Doherty, P. C., 1975, Location of the non-tidal current null zone in Northern San Francisco Bay: Estuarine and Coastal Science, v. 3, p. 1-11.

Title: Alaskan Coastal Environment (VIII-13)

Status: Ongoing FY 76

Location: Alaska

Principal Contact: CA-1

Objective: To perform an integrated study of sedimentation in Turnagain Arm, a 70-kilometre-long estuary near Anchorage, Alaska.

\section{Products:}

Bartsch-Winkler, Susan, Ovenshine, A. T., and Lawson, D. E., 1975, Sedimentological maps of the Gridwood Bar, Turnagain Arm, Alaska, for July-August, 1973; U.S. Geol. Survey Misc. Field Studies Map MF-672, 1 sheet.

Ovenshine, A. T., Lawson, D. E., and Bartsch-Winkler, Susan, 1974, Subsidence, inundation and sedimentation: Environmental consequences of the 
1964 Alaska earthquake in the Portage, Alaska area: U.S. Geol. Survey Earthquake Inf. Bull., v. 6, no. 6, p. 3-9.

1975, An earthquake-caused transgressive deposit in Turnagain Arm, Alaska, USA: Intern. Cong. Sedimentology, 9th Nice 1975, Theme II, Proc., p. 10.

\section{Title: Arctic Nearshore Processes (VIII-14)}

Status: Ongoing FY 76

Location: Alaska

Principal Contact: CA-1

Objective: To investigate the marine geologic and sedimentary processes of the inner shelf and shore of the Beaufort Sea in northern Alaska. The project goal was to study the nature, distribution, and thickness of Holocene sediments and their relationship to sources, dispersal mechanisms, and bottom processes. Emphasis was placed on processes unique to arctic shelves and their sedimentary environment, where sea ice and permafrost play important roles in and are of vital interest to offshore development. Field studies used side-scan sonar, sounding techniques, geophysical surveys, bottom sampling, and thermal measurements. Landsat imagery was also used extensively.

Title: Polar Ice Remote Sensing (VIII-15)

Status: Ongoing FY 76

Location: Arctic Ocean

Principal Contact: WR-1

Objective: To develop the accurate remote sensing methods required to test numerical models of sea ice.

Title: Sea-Ice Dynamics (VIII-16)

Status: Ongoing FY 76

Location: Arctic Ocean and surrounding land masses

Principal Contact: WR-1

Objective: To create arctic ice pack mathematical models to test several theories related to the pack, to develop models of glaciers, and to test these models with field observations.

Title: Circulation Patterns and Sediment Transport in San Francisco Bay and Adjacent Ocean (VIII-17)

Status: Ongoing FY 76

Location: Northwestern California

Principal Contact: WR-1

Objective: To evaluate the seasonal variations in the water quality of the bay. The mass movement of sediment and selected chemical constitutents between the bay and the ocean will be computed.

Title: Coastal Processes (VIII-18)

Status: Completed FY 75

Location: California

Principal Contact: CA-3

Objective: To study coastal processes and conditions primarily as they related to land-use considerations. The study involved inventorying coastal tectonics such as deformed marine terraces and regional variability in 
Holocene eustatic curves; documenting changes in coastal configuration from historical records and identifying the extent of various erosional processes such as landslides and direct wave attack; and identifying the extent of and changes in natural coastal environments such as sand dunes, beaches, and estuaries.

Title: Monterey Bay (VIII-19)

Status: Completed FY 75

Location: California

Principal Contact: CA-3

Objective: To map the geologic structures of Monterey Bay, to establish the geology, structure, tectonic history, genesis, thickness, and depositional history of bay sediments; to determine the distribution and location of freshwater aquifers in the bay; to determine the origin of Monterey Submarine Canyon and its significance as related to the geology of the bay; and to map faults along the Continental Shelf between Point Ano Nuevo and Point Sur and to determine their significance as related to onshore geology, recent seismic events, and modern-day geologic working hypotheses such as sea-floor spreading.

\section{Title: Deposition and Diagenesis of Carbonate Sediments (VIII-20)}

Status: Ongoing FY 76

Location: Florida

Principal Contact: NR-7

Objective: To investigate sedimentary and diagenetic processes and patterns in carbonate Continental Shelf and Margin environments. Modern sediments and sediments of late Pleistocene age are being investigated to determine: Two- and three-dimensional distribution of marine carbonate facies with application to older mineral and hydrocarbon-bearing deposits; the relationship between water chemistry and hydrologic regimen as it relates to leaching (porosity enhancement) and cementation (porosity destruction); the criteria for recognizing and distinguishing the origin of the various kinds of cements peculiar to ancient limestones; and the relationship between organic sediment production and micro- and macroorganism activities.

\section{Title: Environmental Effects in Coral Reef Areas (VIII-21)}

Status: Ongoing FY 76

Location: Florida

\section{Principal Contact: NR-7}

Objective: To determine the environmental parameters of past prepollution conditions through the study of annual banding in massive head corals. A chronology of shallow marine corals will be developed to assist in determining the effects of turbidity and pollutants on corals and coral reefs. Environmental maps of the Florida reef tract showing the distribution of major living and dead reef builders are being prepared.

Title: Estuarine Hydrology of Tampa Bay (VIII-23)

Status: Ongoing FY 76

Location: Central gulf coast, Florida

Principal Contact: FL-1 
Objective: To provide a comprehensive hydrological investigation of Tampa Bay and to assess the impact of a proposed channel-dredging project on the hydrobiologic system of the bay.

Title: Sedimentation and Diagenesis of Modern and Pleistocene Age Limestone (VIII-24)

Status: Ongoing FY 76

Location: Florida

Principal Contact: NR-7

Objective: To investigate the development and destruction of porosity and permeability in modern limestones and limestones of Pleistocene age in marine subaerial and phreatic environments. The purpose is to evaluate and describe processes that may be useful in studying oil and gas reservoirs and to provide information pertinent to seismic modeling and to resource appraisal. Underwater core drilling is conducted in modern reefs to determine porosities, and cores are taken from onshore Pleistocene limestone to study diagenetic cements and leaching resulting from exposure to freshwater in the vadose and phreatic zones and mixed freshwater and saltwater in the lower phreatic zone.

Title: Water-Quality Modeling of Selected Florida Estuaries (VIII-25)

Status: Ongoing FY 76

Location: Florida gulf coast

Principal Contact: FL-1

Objective: To develop digital water-quality models for eight estuaries along the Florida gulf coast. The models will evaluate the effect of waste discharge on dissolved oxygen, biochemical oxygen demand, and chloride.

Title: Effects of Water-Quality Changes on Estuarine Biota (VIII-26)

Status: Ongoing FY 76

Location: Central Maryland

Principal Contact: NR-1

Objective: To understand the effects of man's activities on the ecology of estuaries by studying the biota and its relation to natural and altered environments.

Title: Massachusetts Cooperative Project (VIII-27)

Status: Ongoing FY 76

Location: Massachusetts

Principal Contact: NR-7

Objective: To generate geologic maps of the offshore area adjacent to eastern Massachusetts. Goals are to reconstruct the geologic history of the area and to tie the offshore geology to that already mapped on the land. The Commonwealth's interest is in acquiring basic information on offshore sand and gravel resources. Sonic profiles, magnetometer profiles, and core and grab samples are the data base of mapped information on sediment distribution and thickness, the distribution of glacial deposits and older sedimentary formations of Tertiary and Cretaceous age, the distribution of sedimentary and metasedimentary rocks of Triassic age and older, and the patterns of water movement through the area. 
Title: Collection of Records of Tidal Stage (VIII-28)

Status: Ongoing FY 76

Location: Southern New Jersey

Principal Contact: NJ-1

Objective: To obtain continuous measurements on tidal stage and discharge in the Delaware River estuary.

Title: Remote Sensing of Long Island Sound (VIII-29)

Status: Ongoing FY 76

Location: Long Island Sound, Connecticut shore

Principal Contact: CT-1

Objective: To analyze circulation patterns in Long Island Sound near the Connecticut River outlet.

Title: Flow Modeling of the Chowan River Estuary (VIII-30)

Status: Ongoing FY 76

Location: Northeastern North Carolina

Principal Contact: NC-1

Objective: To prepare a flow model that will assist investigators studying biological processes and the cycling of nutrients in the estuary.

Title: Hydrology of Estuaries and Sounds of North Carolina, With Emphasis on Seawater Encroachments (VIII-31)

Status: Ongoing FY 76

Location: Coastal North Carolina

Principal Contact: NC-1

Objective: To consolidate, summarize, and interpret available data on the chemical and physical hydrology of the estuaries and sounds of North Carolina.

Title: Geological Survey-Puerto Rico Cooperative Project in Marine Geology (VIII-32)

Status: Ongoing FY 76

Location: Puerto Rico

Principal Contact: NR-7

Objective: To initiate a program of geologic investigation and mapping of the insular shelf surrounding Puerto Rico and to train marine geologists and technicians. The study includes collection and analysis of bottom samples, underwater photography, seismic profiling, and bathymetric mapping at a scale of $1: 40,000$. The work will increase knowledge of sand and gravel resources, help locate potentially hazardous geological faults around the island, assess potential oil and gas resources, and update the geological history of the Greater Antilles.

Title: Reconnaissance Investigations of South Carolina Estuaries (VIII-33) Status: Ongoing FY 76

Location: East Coast of South Carolina

Principal Contact: SC-1

Objective: To define saltwater movement in and out of estuaries and the interrelation of saltwater and freshwater in coastal embayments. 
Title: Coastal Geologic Environmental Studies (VIII-34)

Status: Ongoing FY 76

Location: Texas

Principal Contact: CO-1

Objective: To establish a sound base of environmental geologic data that can be used for planning the future development of the Continental Shelf. These activities will assist coastal and inner-shelf engineering projects, including the planning of nuclear power sites and deep-water ports and developing the petroleum resources of the Outer Continental Shelf. Emphasis is placed on understanding the sedimentary processes operative on the Continental Shelf (especially the inner segment), the Holocene sedimentary history of the shelf, the processes and patterns of sediment movement, the geochemistry of the sediments, and the characteristics of the various sedimentary environments.

Product:

Cosby, S. M., 1975. Environmental geologic map of the Harbor Island area, Texas: U.S. Geol. Survey Misc. Field Studies Map MF-687, 1:24,000, 2 sheets and text.

Title: Quality of Water in Texas Bays and Estuaries (VIII-35)

Status: Ongoing FY 76

Location: Texas gulf coast

Principal Contact: TX-1

Objective: To define the physical, inorganic, and organic water-quality characteristics of Texas coastal waterways. Emphasis will be placed on nutrients, suspended sediment, and freshwater movement through the coastal waters.

Title: Influence of Industrial and Municipal Wastes on Estuarine and Offshore Waters (VIII-36)

Status: Ongoing FY 76

Location: Seattle, Washington

Principal Contact: WA-1

Objective: To determine the effects of municipal and industrial wastes on coastal waters. Emphasis is placed on planned treatment facilities discharging wastes into the Puget Sound and the Duwamish River estuary.

\section{IX.-GROUND-WATER STUDIES}

Geological Survey ground-water studies can make direct contributions to the solution of local and regional water problems. These water problems include declining ground-water levels, contamination of fresh ground water by salty water or by domestic or industrial pollutants, and lowering of land surfaces (subsidence) owing to the excessive pumping of underlying artesian aquifers. Cooperative agreements with State, county, and municipal agencies result in jointly planned and supported studies designed to provide the data needed to assess and manage groundwater systems. In addition to defining ground-water availability, cooperative studies provide for long-term monitoring of water 
levels, detection of movement of salty ground water, and acquisition of data on the chemical and physical factors needed to develop ground-water simulation models.

Recent Federal and State legislation directed toward improving ground-water protection and management has prompted local and regional planning agencies to seek solutions for complex groundwater problems. The use of simulation models to analyze such problems has yielded accurate solutions at reasonable costs. Resistor-capacitor analogs and digital computer models are applied in aquifer studies. These models can provide solutions to problems ranging from the drawdown of the water table caused by pumpage from one well or more to the prediction of the impact that a number of alternative water-management strategies will have on preserving the integrity of a freshwater aquifer system.

The Geological Survey has constructed about 102 different resistor-capacitor analog models to aid in resolving ground-water problems, and the number of digital computer models is growing rapidly. Documentation of most of the ground-water models used by the Geological Survey, including a description of the computer program and the various input parameters, is available. In some instances, the documentation includes the results of analyses made to assess model accuracy.

A substantial quantity of the precipitation falling in many areas infiltrates into the ground and recharges ground-water reservoirs. Intensive ground-water development in coastal areas, particularly when it is compounded with the loss of natural recharge to storm sewers, will probably induce salty ground water to move landward and thereby contaminate freshwater supplies. Practically all ground water pumped for man's use is treated and frequently disposed of in the nearest watercourse or in the ocean. This practice results in a direct loss of recharge to the groundwater system. Moreover, intensive pumping of ground water to supply increasing demands often results in marked imbalances in freshwater aquifers.

The Geological Survey is currently involved in several studies to explore the impact of urbanization on recharge in the coastal zone. These research projects are centered principally on Long Island, New York, and in Florida, Texas, and California where serious ground-water problems have evolved. Much of the work centers on the use of diffusion wells to pump highly treated waste water back into the ground-water reservoir. Research efforts focus on field investigations of the physical and chemical processes associated with the recharge of aquifers, the feasibility of artifi- 
cial recharging, and the development of chemical and physical treatment methods to remove particulate matter from water prior to recharge. Much of the work is done in close collaboration with State and county officials who frequently supply funds, manpower, facilities, and data to assist Geological Survey personnel.

As with most other water-related studies, the results of groundwater projects are published as comprehensive reports in Geological Survey publications series or in State, county, or municipal periodicals or as short articles in scientific journals featuring some particular phase of the work.

\section{RELATED ACTIVITIES}

\section{Title: Mathematical Modeling of Geothermal Systems (IX-1)}

Status: Ongoing FY 76

Location: Nationwide

Principal Contact: NR-1

Objective: To examine the computer simulation of heat transport in porous media. A major application is the modeling of geothermal resources to predict the response of the reservoirs to commercial development.

Products:

Mercer, J. W., Faust, C. R., and Pinder, G. F., 1974, Geothermal reservoir simulation: Natl. Sci. Foundation Conf. on Research for the Development of Geothermal Energy Resources, Pasadena, California 1974, Proc., p. 256-267.

Mercer, J. W., and Pinder, G. F., 1974, Finite element analysis of hydrothermal systems, in Finite element methods in flow problems: Oden, J. T., Zienkiewicz, O. C., Gallagher, R. H., and Taylor, C., eds., Univ. of Alabama Press, p. 401-414.

Mercer, J. W., Pinder, G. F., and Donaldson, I. G., 1975, A Galerkin-finite element analysis of the hydrothermal system at Wairakei, New Zealand: Jour. Geophys. Research, v. 80, no. 17, p. 2608-2621.

Title: Geohydrology of the Potomac-Raritan-Magothy Aquifer System, Trenton to Salem (IX-2)

Status: Ongoing FY 76

Location: Southern New Jersey, Philadelphia, Pennsylvania, and New Castle, Delaware

Principal Contact: $\mathrm{NJ}-1$

Objective: To determine the geologic and geochemical characteristics and water-quality potential of this important aquifer system as an aid to water management.

Title: Hydrodynamics and Geochemistry of the Gulf Coast Geopressured Aquifers (IX-3)

Status: Ongoing FY 76

Location: Gulf coast

Principal Contact: NR-1

Objective: To define the chemical and other significant processes affecting ground-water flow and to prepare a simulation model that can be used to predict man's effect on geopressured aquifer systems. 
Product:

Trescott, P. C., 1975, Documentation of finite-difference model for simulation of three-dimensional ground water flow: U.S. Geol. Survey Open File Rept. 75-438, 32 p. and 6 appendices.

Title: Development and Use of Digital Ground-Water Flow and Quality Models of the Salinas Valley, Monterey County, California (IX-4)

Status: Ongoing FY 76

Location: West-central California

Principal Contact: CA-1

Objective: To develop models of ground-water flow and quality to assist the U.S. Army Corps of Engineers in assessing the effect of alternative plans for managing the area's water resources.

Title: Geology and Ground Water in Santa Cruz County, California (IX-5) Status: Ongoing FY 76

Location: Central coastal California

Principal Contact: CA-1

Objective: To describe the ground-water system in sufficient detail to allow planners to evaluate the impact on the system of proposed management decisions.

Product:

Muir, K. S., 1974, Sea water intrusion, ground-water pumpage, ground-water yield, and artificial recharge of the Pajaro Valley area, Santa Cruz and Monterey Counties, California: U.S. Geol. Survey Water-Resources Inv. 9-74, $31 \mathrm{p}$.

Title: Monitoring Ground-Water Quality in the Suisun Bay Area, Contra Costa, Solano, and Sacramento Counties, California (IX-6)

Status: Ongoing FY 76

Location: Central coastal California

Principal Contact: CA-1

Objective: To evaluate the consequences to the ground-water system of deepening a ship channel in the Suisun Bay area.

Product:

Akers, J. P., 1974, The effect of proposed deepening of the John F. Baldwin and Stockton Ship Channels on salt-water intrusion, Suisun Bay and Sacramento-San Joaquin Delta areas, California: U.S. Geol. Survey Water-Resources Inv. 56-73, $10 \mathrm{p}$.

Title: Biscayne Aquifer Analog Model Study in Southeastern Florida (IX-7)

Status: Ongoing FY 76

Location: Southeastern Florida

Principal Contact: FL-1

Objective: To use an analog model to analyze alternative decisions for regulating an existing aquifer-canal system.

Product:

Appel, C. A., 1966, Approximating steady linear flow in a confined aquifer of nonuniform thickness: U.S. Geol. Survey Prof. Paper 550-D, 214-216. 
Title: City of Sarasota, Disposal Test Well, Phase 1 (IX-8)

Status: Ongoing FY 76

Location: Southwestern Florida

Principal Contact: FL-1

Objective: To investigate the possibility of disposing of waste in a deep saline aquifer.

Title: Deep Well Injection, Fort Lauderdale, Florida (IX-9)

Status: Ongoing FY 76

Location: Southeastern Florida

Principal Contact: FL-1

Objective: To evaluate the capability of a deep aquifer to receive large quantities of effluent and to determine the impact of construction and operation of the injection well on overlying aquifers.

Title: Digital Model for Determining Aquifer Response in Southeastern Palm Beach County, Florida (IX-10)

Status: Ongoing FY 76

Location: Southeastern Florida

Principal Contact: FL-1

Objective: To develop a mathematical model simulating the ground-water reservoir underlying the county for the purpose of predicting the effect on the saltwater-freshwater interface of increased freshwater pumping.

Title: Effects of Ground-Water Withdrawals on Water Quality Along Tampa Bay, Southwestern Hillsborough County (IX-11)

Status: Ongoing FY 76

Location: West-central Florida

Principal Contact: FL-1

Objective: To provide background information on the water-resource problems of this rapidly growing area. The data will be helpful in defining the extent of the regulation that may be needed to protect ground-water supplies.

Title: Effects of Solid-Waste Landfills on Ground-Water Quality, Dade County, Florida (IX-12)

Status: Ongoing FY 76

Location: Southeastern Florida

Principal Contact: FL-1

Objective: To determine the pollutants in leachate, their direction and movement, and the filter effect of limestone aquifers on leachate in an effort to minimize the threat posed to the Dade County water supply by the disposal of solid wastes.

Title: Feasibility of Artificial Recharge, Tricounty Area of Hillsborough, Pasco, and Pinellas Counties, Florida (IX-13)

Status: Ongoing FY 76

Location: West-central Florida

Principal Contact: FL-1

Objective: To evaluate the feasibility of using artificial recharge as a management tool to minimize water-user conflicts and to provide for a more efficient water-supply system. 
Title: Ground-Water Conditions in the Cocoa Well Field Area (IX-14)

Status: Ongoing FY 76

Location: Central Florida

Principal Contact: FL-1

Objective: To provide the city of Cocoa with water information that will protect it from future saltwater problems, such as the increase in the amount of chlorides in water pumped by the city that forced the abandonment of some wells.

Title: Ground-Water Studies in Central Broward County, Florida (IX-15) Status: Ongoing FY 76

Location: Southeastern Florida

Principal Contact: FL-1

Objective: To assess the impact of increased ground-water withdrawals and to monitor the freshwater-saltwater boundary in the important Floridan aquifer.

Title: Hydrogeologic Factors Affecting the Availability and Quality of Ground Water in Temple Terrace Area, Florida (IX-16)

Status: Ongoing FY 76

Location: West-central Florida

Principal Contact: FL-1

Objective: To develop guidelines that will aid Temple Terrace in expanding its water supply and minimizing the water-quality problems that accompany rapid urbanization.

Title: Hydrogeology of the Varna Well Field, Sarasota, Florida (IX-17)

Status: Ongoing FY 76

Location: Southwestern Florida

Principal Contact: FL-1

Objective: To determine the most efficient method of removing water from the water-table aquifer and to evaluate the effectiveness of various methods of inducing the recharge of surface water into shallow aquifers.

Title: Hydrologic Effects of Injecting Treated Waste Water into a Deep Saline Aquifer at West Palm Beach, Florida (IX-18)

Status: Ongoing FY 76

Location: Southeastern Florida

Principal Contact: FL-1

Objective: To evaluate the potential use of a deep saline aquifer as a wastemanagement site for the disposal of sewage.

Title: Hydrology and Geochemistry of Artificial Recharge and Reuse of Freshwater Stored in Deep Saline Aquifers in Southeastern Florida (IX-19)

Status: Ongoing FY 76

Location: Southeastern Florida

Princial Contact: FL-1

Objective: To evaluate the hydrologic and geochemical factors related to the use of saline aquifers for the storage, conservation, and recovery of freshwater. 
Title: Hydrology, Central Volusia County, Florida (IX-20).

Status: Ongoing FY 76

Location: East-central Florida

Principal Contact: FL-1

Objective: To create a model that will assess the impact of land-use decisions on ground-water development.

Title: Hydrology of Sarasota County (IX-21)

Status: Ongoing FY 76

Location: Southwestern Florida

Principal Contact: FL-1

Objective: To evaluate the availability of fresh ground water in a specific part of Sarasota County.

Title: Hydrology of the Sand-and-Gravel Aquifer, Pensacola, Florida (IX22)

Status: Ongoing FY 76

Location: Northwestern Florida

Principal Contact: FL-1

Objective: To determine the quantity and quality of water in the only freshwater aquifer in the Pensacola area.

Title: Investigation of the Use of Deep Wells for Waste Disposal Near Pensacola, Florida (IX-23)

Status: Ongoing FY 76

Location: Western Florida panhandle

Principal Contact: FL-1

Objective: To provide the means for evaluating some of the hydrologic and geochemical effects of injecting acidic industrial wastes into a limestone aquifer.

Product:

Faulkner, G. L., and Pascale, C. A., 1975, Monitoring regional effects of rig pressure injection of industrial waste water in a limestone aquifer: Ground Water, v. 13, no. 2, p. 197-208.

Title: Potential of the Shallow Aquifer in Brevard County (IX-24)

Status: Ongoing FY 76

Location: East-central Florida

Principal Contact: FL-1

Objective: To evaluate the total freshwater potential of the Titusville well field.

Title: Storage and Use of Storm Waters, St. Petersburg, Florida (IX-25)

Status: Ongoing FY 76

Location: West-central Florida

Principal Contact: FL-1

Objective: To determine the hydrogeological effects of injecting storm runoff into aquifers.

Title: Subsurface Disposal, Pinellas County, Florida (IX-26)

Status: Ongoing FY 76

Location: West-central Florida 
Principal Contact: FL-1

Objective: To determine whether it is feasible to inject highly treated sewage into shallow parts of the Flordian aquifer as a means of disposing of sewage effluent somewhere other than at sea.

Title: Urban Hydrology of the Englewood Water District (IX-27)

Status: Ongoing FY 76

Location: Southwestern Florida

Principal Contact: FL-1

Objective: To identify the various aquifers capable of yielding high-quality water in this rapidly growing area.

Title: Water Resources of Martin County, Florida (IX-28)

Status: Ongoing FY 76

Location: Southeastern Florida

Principal Contact: FL-1

Objective: To analyze the aquifer system underlying Martin County.

\section{Title: Water Resources of Riviera Beach, Florida (IX-29)}

Status: Ongoing FY 76

Location: Southeastern Florida

Principal Contact: FL-1

Objective: To establish monitoring wells around the existing Riviera Beach well field to detect saltwater intrusion and to assist planners in their efforts to increase pumpage.

Title: Water Resources of Tequesta Area, Florida (IX-30)

Status: Ongoing FY 76

Location: Southeastern Florida

Principal Contact: FL-1

Objective: To seek methods of increasing the capacity of the Tequesta well field without inducing further saltwater encroachment.

Title: Water Resources of the Hallandale Area, Florida (IX-31)

Status: Ongoing FY 76

Location: Southeastern Florida

Principal Contact: FL-1

Objective: To determine locations that will probably yield the maximum volume of good-quality water. The continued growth of Hallandale has necessitated expansion of its well field.

Title: Water Resources of the Hollywood, Florida, Area (IX-32)

Status: Ongoing FY 76

Location: Southeastern Florida

Principal Contact: FL-1

Objective: To determine areas most likely to yield the best supplies of ground water.

Product:

Bearden, H. W., 1974, Ground water resources of the Hollywood area, Florida: Fla. Dept. of Nat. Resources, Bur. of Geol. Rept. of Inv., no. $77,35 \mathrm{p}$. 
Title: Water Resources of Palm Beach County, Florida (IX-33)

Status: Ongoing FY 76

Location: Southeastern Florida

Principal Contact: FL-1

Objective: To delineate the extent of saltwater encroachment in coastal aquifers and the effect of sanitary landfills on ground-water quality.

Title: Ground-Water Resources of the North Windham-Freeport Area, Maine (IX-34)

Status: Ongoing FY 76

Location: Southeastern Maine

Principal Contact: MA-1

Objective: To determine the location, extent, quantity, and quality of aquifers underlying the North Windham-Freeport area.

Title: Aquifer Studies in Maryland (IX-35)

Status: Ongoing FY 76

Location: Coastal plain of Maryland

Principal Contact: MD-1

Objective: To predict the hydraulic effects and water-quality changes resulting from pumping. Models of the ground-water system will be developed to assist the State in providing effective ground-water management.

Product:

Papadopulos, S. S., and others, 1974, Water from the coastal plain aquifers in the Washington, D.C., metropolitan area: U.S. Geol. Survey Circ. $697,11 \mathrm{p}$.

Title: A Digital Simulation Model of the Cape Cod Aquifer, Massachusetts (IX-36)

Status: Ongoing FY 76

Location: Eastern Massachusetts

Principal Contact: MA-1

Objective: To develop a computer model of the ground-water system to demonstrate the changes that proposed water-development schemes will have on ground-water supplies.

Title: Ground-Water Modeling of Muskegan County Wastewater Treatment Facility (IX-37)

Status: Ungoing FY 76

Location: West-central Michigan

Principal Contact: MI-1

Objective: To obtain data on ground-water characteristics in the immediate vicinity of the treatment facility to ensure development of an accurate predictive model.

Title: Ground-Water Resources of Western Upper Peninsula, Michigan (IX-38)

Status: Ongoing FY 76

Location: Northwestern Michigan

Principal Contact: MI-1

Objective: To provide information on the quantity and quality of ground water so that its potential sources can be used and protected. 
Title: Geology and Ground-Water Resources of Camden County (IX-39)

Status: Ongoing FY 76

Location: Southwestern New Jersey

Principal Contact: NJ-1

Objective: To investigate the extent of man's impact on the aquifer system as a result of industrial and suburban development in Camden County.

Title: Geohydrologic Analysis of the Mount Laural-Wenonah Formations (IX-40)

Status: Ongoing FY 76

Location: Southern New Jersey

Principal Contact: NJ-1

Objective: To quantitatively assess the geohydrologic character and water quality of this aquifer system to provide planners with a means of assessing its optimal development.

Title: Geohydrology of the Potomac-Magothy Aquifer System, Trenton to Perth Amboy (IX-41)

Status: Ongoing FY 76

Location: Northern coastal New Jersey

Principal Contact: NJ-1

Objective: To determine the geologic and geochemical characteristics and water-quality potential of this important aquifer system.

Product:

Winograd, I. J., and Farlekas, G. M., 1974, Problems in carbon-14 dating of water from aquifers of deltaic origin-an example from the New Jersey coastal plain: Internat. Atomic Energy Symposium on Isotope Techniques in Ground Water Hydrology, Vienna March 1974, Proc., p. 69-93.

Title: Test Drilling, Geophysical Logging, and New Observation Wells, Coastal Plain (IX-43)

Status: Ongoing FY 76

Location: Southern New Jersey

Principal Contact: NJ-1

Objective: To aid in defining the areal extent and thickness of coastal aquifers and the location of the freshwater-saltwater interface.

Title: Appraisal of Hydrologic Conditions in Suffolk County, New York (IX-44)

Status: Ongoing FY 76

Location: Suffolk County, New York

Principal Contact: NY-1

Objective: To combine the results of previous studies with recent information to evaluate the ground-water resources of the area.

Title: Artificial Recharge of Treated Sewage Water at Bay Park, New York (IX-45)

Status: Ongoing FY 76

Location: Nassau County, New York

Principal Contact: NY-1 
Objective: To test the feasibility of injecting treated sewage into a deep fresh-water aquifer. The study will assist in assessing the mechanics, difficulties, and costs associated with the artificial recharge of highly treated sewage.

Title: Changes in Natural and Artificial Ground-Water Recharge on Long Island, New York (IX-46)

Status: Ongoing FY 76

Location: Long Island, New York

Principal Contact: NY-1

Objective: To evaluate the overall effectiveness of recharging the groundwater system on Long Island by about 2,000 open pits, whose prime purpose is to allow rapid infiltration of storm runoff.

Title: Design and Support of Suffolk County, New York, Water-Quality Observation Well Program (IX-47)

Status: Ongoing FY 76

Location: Long Island, New York

Principal Contact: NY-1

Objective: To establish a baseline water-quality data bank to help assess future water-quality deterioration. The water quality of the groundwater reservoir (especially the shallow water-table aquifer) is of major concern in this area.

Title: Evaluation of Feasibility of Deep-Well Waste Disposal in Western New York and Prediction of Reaction of Aquifer System to Applied Stresses (IX-48)

Status: Ongoing FY 76

Location: Western New York

Principal Contact: NY-1

Objective: To provide an understanding of the interactions of injected waste water with the carbonate rocks that underlie parts of western New York.

Title: Laboratory Column Studies of the Effects of Percolation of Reclaimed Sewage Effluent Through Native Soil Materials (IX-49)

Status: Ongoing FY 76

Location: Long Island, New York

Principal Contact: NY-1

Objective: To define the infiltration characteristics of surficial deposits in Nassau County under the application of reclaimed sewage effluent.

Title: Prototype Electrical Analog Model of Western Long Island, New York (IX-50)

Status: Ongoing FY 76

Location: Long Island, New York

Principal Contact: NY-1

Objective: To construct a model that will provide decisionmakers with quantitative estimates of changes in the ground-water system resulting from various proposed water-management schemes. 
Title: Water Quality of Selected Solid-Waste Disposal Cites, Suffolk County, Long Island, New York (IX-51)

Status: Ongoing FY 76

Location: Long Island, New York

Principal Contact: NY-1

Objective: To document the nature and extent of changes in the quality of ground water in the vicinity of solid-waste disposal sites. There is concern about leachate percolating into the shallow aquifer system.

Products :

Kimmel, G. E., and Braids, O. C., 1974, Leachate plumes in a highly permeable aquifer: Ground Water, v. 12 , no. 6, p. 388-393.

1975, Preliminary findings of a leachate study on two landfills in Suffolk County, New York: U.S. Geol. Survey Jour. of Research, v. 3, no. 3, p. 273-280.

Title: Hydrology of Dune Aquifers near Coos Bay, Oregon (IX-52)

Status: Ongoing FY 76

Location: Southern Oregon coast

Principal Contact: OR-1

Objective: To minimize the adverse effects of extensive anticipated industrial and recreational development on the area's ground-water sources by making a thorough study of the underlying aquifer system.

Title: Hydrology and Geology of Erie County (IX-53)

Status: Ongoing FY 76

Location: Northwestern Pennsylvania

Principal Contact: PA-1

Objective: To determine the availability and quality of ground water in Erie County.

Title: Low Country Capacity Use Study (IX-54)

Status: Ongoing FY 76

Location: Southeastern South Carolina

Principal Contact: SC-1

Objective: To assess the availability of ground water and to provide meaningful data for water-management decisions.

Title: Continuing Quantitative Ground-Water Studies in the Houston District (IX-55)

Status: Ongoing FY 76

Location: Houston, Texas

Principal Contact: TX-1

Objective: To provide this Texas coastal area with current information on its ground-water resources.

Products:

Gabrysch, R. K., Naftel, W. L., and McAdoo, G. D., 1974, Ground-water data for Harris County, Texas, v. III, Chemical analyses of water from wells, 1922-71: Texas Water Devel. Board Rept. 178, 87 p.

Gabrysch, R. K., Naftel, W. L., McAdoo, G. D., and Bonnet, C. W., 1974, Ground-water data for Harris County Texas, v. II, Records of wells, 1892-1972: Texas Water Devel. Board Rept. 178, 181 p. 
Title: Ground-Water Resources of Galveston County (IX-56)

Status: Ongoing FY 76

Location: Galveston, Texas

Principal Contact: TX-1

Objective: To provide a continuing program of basic-data collection to ensure an adequate data base for water-management decisions.

Title: Hydrogeology of the Wilcox Group, Texas (IX-57)

Status: Ongoing FY 76

Location: Gulf Coastal Plain, Texas

Principal Contacts TX-1

Objective: To assess the suitability of this geologic formation for storing liquid wastes.

Title: Continuing Ground-Water Studies in Orange County and Adjacent Areas (IX-58)

Status: Ongoing FY 76

Location: East-central Texas

Principal Contact: $\mathrm{TX}-1$

Objective: To gather current information on the ground-water resources of Orange County and to monitor and suggest methods of avoiding saltwater encroachment of freshwater aquifers.

Title: Land-Surface Subsidence, Texas City and Seabrook Areas, Texas (IX-59)

Status: Ongoing FY 76

Location: Southeastern Texas

Principal Contact: TX-1

Objective: To predict the amounts and rates of subsidence for planning, constructing, and maintaining levees used for flood protection.

Title: Model Study, Chicot and Evangeline Aquifers, Texas Gulf Coast (IX-60)

Status: Ungoing FY 76

Location: Texas gulf coast

Principal Contact: TX-1

Objective: To develop a ground-water model that will define the quantitative relationship between the geologic framework and the hydrologic system. The results will be presented to water-supply planners.

Title: Model Study of the Jasper and Catahoula Aquifers in the Gulf Coastal Region of Texas (IX-61)

Status: Ongoing FY 76

Location: Texas gulf coast

Principal Contact: $\mathrm{TX}-1$

Objective: To use a model simulating the flow in the Jasper-Catahoula aquifer system in order to provide information for use in planning and managing the water supply obtained from the system.

Title: Saltwater Encroachment, Houston Area, Texas (IX-62)

Status: Ungoing FY 76

Location: Southeastern Texas 
Principal Contact: $\mathrm{TX}-\mathbf{1}$

Objective: To locate the freshwater-saltwater interfaces in aquifers and to isolate the sources of contamination to shallow wells.

Title: Chemical Quality of Ground Water in Coastal Plain of Virginia (IX-63)

Status: Ongoing FY 76

Location: Southeastern Virginia

Principal Contact: VA-1

Objective: To make the extensive chemical data on ground water in the Geological Survey District Office files available to the public and to Federal, State, and local agencies.

Title: Ground-water Resources South of the James River, Virginia (IX-64)

Status: Ongoing FY 76

Location: Southeastern Virginia

Principal Contact: VA-1

Objective: To evaluate the freshwater supply and the impact of heavy pumping on aquifer water levels, in this area, where heavy ground-water withdrawals have caused concern about the future usefulness of the supply.

Title: Occurrence and Quality of Ground Water in the Coastal Plain of Virginia (IX-65)

Status: Ongoing FY 76

Location: Eastern Virginia

Principal Contact: VA-1

Objective: To define the aquifer system in the coastal plain, specifically by mapping water-quality characteristics, water levels and pressure heads, and areas of recharge and discharge.

Title: Ground-Water Resources of the Long Beach Peninsula, Pacific County, Washington (IX-66)

Status: Ongoing FY 76

Location: Washington

Principal Contact: WA-1

Objective: To describe the present ground-water conditions and to estimate the amount of water that can be developed in this area of rapid population growth.

Title: Ground-Water Resources of the Squaxin Indian Reservation (IX-67)

Status: Ongoing FY 76

Location: West-central Washington

Principal Contact: WA-1

Objective: To define the ground-water conditions on the reservation and to enable the Indians to protect their water rights by estimating the usable supply and suggesting sites for pumping.

Title: Test Drilling (IX-68)

Status: Ongoing. FY 76

Location: Washington

Principal Contact: WA-1

Objective: To monitor saltwater intrusion in coastal areas. 
Title: Digital Computer Model Study of the Sandstone Aquifer in Southeastern Wisconsin (IX-69)

Location: Southeastern Wisconsin

Principal Contact: WI-1

Objective: To simulate the aquifer responses to various planned pumping alternatives.

Title: Geology and Ground-Water Resources of Washington and Ozaukee Counties, Wisconsin (IX-70)

Status: Ongoing FY 76

Location: Southeastern Wisconșin

Principal Contact: WI-1

Objective: To collect and evaluate hydrologic and geologic data pertaining to the ground-water resources of both counties.

Title: Ground-Water Contamination Potential in the Dolomite Aquifer of Eastern Wisconsin (IX-71)

Status: Ongoing FY 76

Location: Eastern Wisconsin

Principal Contact: WI-1

Objective: To determine areas where ground-water quality is, or will be, a problem. The types and sources of the contamination will be identified by water-quality analyses.

\section{X.-SURFACE-WATER STUDIES}

The U.S. Geological Survey measures the surface-water discharge to the Great Lakes, the Gulf of Mexico, and the oceans at 774 gaging stations. Through September 1960, surface-water records were published in an annual series of Geological Survey Water Supply Papers. Beginning October 1960, annual Water Resources Data reports for each State have been released by the Geological Survey. Average daily discharges are published for each stream-gaging station as well as the extreme highest and lowest flows both for a particular reporting year and for the entire period of record. For lake and reservoir stations, records of stage and the quantity of water impounded are published.

Surface-water data are used for many purposes such as evaluating the water supply available to a town or city, in designing bridges and culverts, or assessing the flood potential along a particular watercourse. A well-designed streamflow-gaging network is of considerable value in studies attempting to assess man's impact on the hydrologic cycle. For example, urbanization will change streamflow patterns because of street paving, home and building construction, and the installation of sewers. These activities alter such important water-basin characteristics as infiltration rates, generated volume of storm flow, and the time required for water to move from any point in the basin to the 
stream channel. To assess the extent to which the flow patterns in an urbanized basin are altered, a sufficiently long record covering the period of accelerated land use change is necessary. The impact of urbanization on runoff patterns is currently being evaluated in coastal areas of New York, Florida, South Carolina, and Texas.

One of the principal problems faced by highway engineers is the need for flood data on drainage areas of less than 50 square miles (130 square kilometres). Flood information is usually available on larger streams because they are normally monitored by one or more stream-gaging stations. Peak-discharge information for small streams are required for the design of culverts, bridges, and other highway drainage facilities. The Geological Survey has developed a rainfall/runoff computer model capable of predicting peak flows at a specific streamflow site.

Because of tidal currents, shifting winds, and varying amounts of freshwater inflow, the movement of water in estuaries, bays, and coastal waterways is difficult to measure. For example, diverting a large supply of freshwater into an estuary may completely alter its flow patterns resulting in shoaling, siltation of ship channels, and unwanted changes in the aquatic ecosystem. The development of large computers has permitted modeling of flow in complex water bodies. Flow models enable managers to predict the consequences that changes or adjustments in the hydrologic or physical environment will have on water movement in an estuary. Flow models of Tampa Bay were used to predict the impact of channel dredging on flushing rates in the bay. Modeling of Savannah Bay will permit an evaluation of benefits from a reduction in dredging resulting from the rediversion of upstream runoff.

High-altitude photography and satellite imagery are being used to define circulation patterns and to assist hydrologists in improving estimates of streamflow at ungaged sites. Circulation patterns along the south shore of Lake Ontario and the Connecticut River estuary are identified by turbid plumes formed at the mouths of large discharging watercourses. Remote sensors are also capable of detecting longshore plumes which are indicative of active beach erosion. Improved estimates of streamflow at ungaged sites were obtained for the Delmarva Peninsula by incorporating land use information derived from high-altitude photographs into standard Geological Survey gaging-station analyses. 
One of the major problems confronting flood forecasters and water managers is the lack of instantaneous data on rapid hydrologic changes which may be occurring within their jurisdictions. By using the Landsat satellites, Geological Survey scientists have been able to relay river-stage information from remote radio transmitters, called Data Collection Platforms, to the National Headquarters in Reston, Va. Implementation and continued development of this emerging technology will yield near real-time data available for rapid retrieval and dissemination. Thus, riverstage data from carefully placed remote stations can be made available to any interested agency with sufficient speed to ensure improved flood forecast accuracy and to facilitate management decisions.

\section{RELATED ACTIVITIES}

Title: Hydrodynamic Study on the Transport of Thermal, Physical, and Chemical Constituents in Turbulent Surface Water (X-1)

Status: Ongoing FY 76

Location: Nationwide-emphasis on east coast watercourses

Principal Contact: NR-1

Objective: To develop mathematical models to stimulate such factors as thermal diffusion and nutrient transport.

Title: Numerical Simulation of Hydrodynamic Processes in Rivers, Estuaries and Embayments (X-2)

Status: Ongoing FY 76

Location: Nationwide-emphasis on east coast watercourses

Principal Contact: NR-1

Objective: To develop computer-simulation models which will explore solutions to problems involving waste movement and dispersion in rivers, estuaries, and embayments.

Title: Near Real-Time Water Resources Data for Delaware River Basin Management using the Landsat Satellite (X-3)

Status: Ongoing FY 76

Location: Delaware River basin-New York, New Jersey, Pennsylvania, and Delaware

Principal Contact: PA-1

Objective: To evaluate the feasibility of using satellites as a means of transmitting water information in near real-time to water-resources agencies.

Title: Surface-Water Stations-Connecticut (X-4)

Status: Ongoing FY 76

Location: Connecticut

Principal Contact: CT-1

Objective: To collect surface-water data sufficient to satisfy the needs of users for purposes of surveillance, planning, design, hazard-warning operation, and management. 
Title: Hydrology of Urban Areas in the Tampa Bay Region (X-5)

Status: Ongoing FY 76

Location: West central Florida

Principal Contact: FL-1

Objective: To assess the effect on water resources of continued urbanization, which has increased storm runoff, by investigating streamflow, rainfall, and water quality of runoff.

Title: Flood Insurance Studies for Federal Insurance Administration, Dept. of Housing and Urban Development (HUD) (X-6)

Status: Ongoing FY 76

Location: Northeastern Illinois

Principal Contact: IL-1

Objective: To conduct the necessary flood studies of areas assigned by the Federal Insurance Administration.

Product:

Camp, J. D., 1974, Flood insurance study (Type 15) Des Plaines, Illinois: Dept. of Housing and Urban Development, Federal Insurance Adm. Flood Insurance Rept.

Title: Flood Insurance Studies for Federal Insurance Administration, HUD $(\mathrm{X}-7)$

Status: Ongoing FY 76

Location: Michigan

Principal Contact: MI-1

Objective: To conduct the necessary flood studies of areas assigned by the Federal Insurance Administration.

Product:

Knutilla, R. L., and Herreid, W. D., 1974, Flood insurance study of Monroe, Michigan: Dept. of Housing and Urban Development, Federal Insurance Adm. Flood Insurance Rept.

Title: Operational Models of Surface-Water Systems (X-8)

Status: Ongoing FY 76

Location: Southern Mississippi

Principal Contact: GA-1

Objective: To develop operational models of surface-water systems.

Products:

Bauer, D. P. and Mackenroth, E., 1974, One-dimensional stream excess temperature analysis: U.S. Geol. Survey computer contribution, [Nov. 1974], $35 \mathrm{p}$.

Jeffcoat, H. H., Jennings, M. E., and Peterson, J. B., 1974, Lakes MarionMoultrie stream system investigation: Part I-Model selection calibration, and error analysis: U.S. Geol. Survey Water-Resources Inv. Rept., 25-74.

Moench, A. F., Sauer, V. B. and Jennings, M. E., 1974, Modification of routed streamflow by channel loss and base flow: Water Resources Research, v. 10, no. 5, p. 963-968.

Title: The Determination of the Frequency of Drought Flows of Varying Degrees of Severity and Duration (X-9)

Status: Ongoing FY 76 
Location: New Jersey

Principal Contact: NJ-1

Objective: To provide information on drought flows to assist in water-supply analyses, waste-dilution studies, and the adequacy of surface supplies for cooling water and power generation.

Title: Flood Insurance Studies for Federal Insurance Administration, HUD $(\mathrm{X}-10)$

Status: Ongoing FY 76

Location: New York

Principal Contact: NY-1

Objective: To conduct the necessary flood studies of areas assigned by the Federal Insurance Administration

Title: Flood Investigation-New York (X-11)

Status: Ongoing FY 76

Location: New York

Principal Contact: NY-1

Objective: To provide information on the magnitude and frequency of floods to agencies and individuals involved in various phases of flood planning.

Title: Hydrologic Interpretations Based on Remote-Sensing Techniques (X-12)

Status: Ongoing FY 76

Location: New York-Lake Ontario basin

Principal Contact: NR-1

Objective: To perform studies of circulation patterns along the south shore of Lake Ontario which will assist in model verification and in defining waste movement in the lake.

Product:

Pluhowski, E. J., 1975, Dynamics of turbidity plumes in Lake Ontario: Am. Soc. of Civil Engineers Natl. Conv., Denver, Colo., Nov. 1975, Mtg. Preprint 2602, $28 \mathrm{p}$.

Title: Surface-Water Inflow to Lake Ontario (X-13)

Status: Ongoing FY 76

Location: New York-Lake Ontario basin

Principal Contact: NY-1

Objective: To determine the surface-water flow into Lake Ontario from New York State. This work was done in connection with the International Field Year for the Great Lakes.

Title:Surface-Water Stations, New York (X-14)

Status: Ongoing FY 76

Location: New York

Principal Contact: NY-1

Objective: To collect surface-water data sufficient to satisfy the needs for current-purpose uses such as assessment of water resources, operation of reservoirs, forecasting, or the disposal of wastes.

Title: Flow and Quality Water Model of Santee River (X-15)

Status: Ongoing FY 76

Location: Eastern South Carolina 
Principal Contact: SC-1

Objective: To develop a digital computer model capable of predicting discharge in the lower Santee River prior to and following rediversion of flow from the Cooper River.

Title: Urban Hydrology Study-Houston, Texas (X-16)

Status: Ongoing FY 76

Location: Texas

Principal Contact: TX-1

Objective: To provide hydrologic data for urban studies to delineate floodhazard areas, and to define the effects of urbanization on flood discharge.

Title: Hydrologic Effects of Dredging Small Spring Ponds (X-17)

Status: Ongoing FY 76

Location: Northeast Wisconsin

Principal Contact: WI-1

Objective: To determine the effects of dredging small ponds on the hydrology of the ponds and the surrounding areas.

\section{XI.-RIVER -WATER QUALITY AND SEDIMENTATION STUDIES}

One of the principal objectives of the Geological Survey's water-quality and river-sedimentation research is to detect and monitor contamination of water resources due to man's activities. Degradation of the Nation's water sources is capable of adversely affecting living organisms. By way of illustration, an increasing number of pesticides have been banned or severely limited in application because of their documented or suspected adverse effects on plants and animals. These effects vary from a lowering of the survival rate of newly hatched fish to causing cancer and birth defects in humans.

The introduction and expanded use of laundry detergents during the 1950's and early 1960's resulted in frequent complaints of foaming and unpleasant drinking waters obtained from shallow wells in part of Long Island, New York. The ensuing public clamor and legislation banning sales of suspected detergents in Suffolk County, New York, did much to force manufacturing changes designed to reduce the unwanted persistence of detergent foaming. Since the mid-1960's when detergent manufacturers altered their products, there has been a marked reduction in the number of complaints made regarding drinking-water foaming.

These are but a few of the types of problems associated with man-induced water contamination. Reconnaissance and monitoring of any water-quality constituent requires a comprehensive, well-planned network of water-quality measuring stations to provide the basic data needed to prepare interpretive studies. 
The Geological Survey has been engaged in water-quality studies since 1911. Currently, water-quality measurements of streamflow to the Great Lakes, Gulf of Mexico, and the oceans are collected at 369 gaging stations. Periodic measurements of suspended-sediment concentration are made at numerous sites in the coastal zone to define stream scour and deposition, beach replenishment and erosion, and reservoir and lake siltation. Man's impact on sediment production is being actively studied at several sites in the coastal zone, as are changes in water chemistry due to suspended waterborne matter.

Several studies are being conducted to determine the amount of sediment being carried into the Great Lakes. Shoaling, siltation of harbor facilities, and sharply increased nutrient loading are some of the problems associated with stepped-up sediment production due to changing land use practices. The objective of these studies is to evaluate natural levels of sediment production and to determine the impact on erosion rates of clearing forestlands for agricultural and urban development.

Computer models simulating water quality are being developed to predict changes in water chemistry stemming from man's activities. Research toward development of a water-quality model capable of predicting the effect that heated waters discharged from powerplants will have on stream temperatures is nearly completed. Models predicting the impact on dissolved-oxygen levels resulting from dumping waste water and sewage into estuaries are currently being researched. Plans are being formulated to develop models capable of predicting the movement and dispersion of phosphorous and nitrogen in lakes and estuaries. These nutrients are often responsible for the proliferation of algal blooms in lakes and estuaries. Algal blooms are aesthetically displeasing and frequently result in fish kills and offensive odors. Bioenvironmental models capable of predicting the impact of man-induced water-quality alterations on freshwater and estuarine ecosystems are a long-term goal of the Geological Survey's water-quality modeling research.

An expanding part of the Geological Survey's water-quality research has been directed toward understanding the role of organic chemicals in water. Particular emphasis is placed on defining the impact of these chemicals on aquatic biology. Organic substances contain compounds of carbon and hydrogen and are important in water for many reasons. The bacteriological oxidation of organic carbon from natural sources and from municipal, industrial, and agricultural wastes is a major factor leading to the depletion of life-supporting oxygen in streams and estuaries. 
Natural organic substances may impart color and odor to water and often act as carriers of toxic trace metals, pesticides, and nutrients by chemically combining with them or by facilitating their adsorption on suspended sediment.

Geological Survey research projects having primary emphasis on aquatic biology are widely varied in their objectives and approaches. They are mostly problem oriented and, in the coastal zone, focus primarily on wetlands and estuaries. Aquatic studies along the east coast center on the Rhode River estuary of Maryland and the Great Dismal Swamp of:Virginia. Remote-sensing data are being applied to the Great Dismal Swamp to provide a relatively inexpensive, rapid method of wetland classification, and to evaluate the impact of man's activities on vegetation within the swamp. Studies in Alaska are directed toward evaluating the potential impact of the Alaska pipeline and its associated terminal facilities on estuarine and stream biotic communities.

Research in water chemistry is directed principally toward improving our ability to provide accurate quantitative descriptive information about the Nation's water resources. Several projects are oriented toward development of better methods of chemical analysis or techniques for analyses of important substances never previously measured. Another objective in waterchemistry research is to learn more about the chemical controls that govern the behavior of constituents we can measure. An understanding of these controls helps, for example, to design environmental studies by providing a guide as to where and when to sample, and how to interpret the results.

\section{RELATED ACTIVITIES}

Title: Water-Quality Model Development and Implementation (XI-1)

Status: Ongoing FY 76

Location: Nationwide

Principal Contact: NR-1

Objective: To develop computer-simulation models capable of evaluating the interactions of waste matter in surface-water and ground-water sysems. Product :

Leendertse, J. J., and Liu, S. K., 1974, Comparison of observed tide data of Jamaica Bay with hydraulic model data by use of cross-spectral density functions: The Rand Corp., WN-8703-NYC.

Title: Rates and Processes of Erosion and Sedimentation in Natural and Disturbed Forested Drainage Basins in the Douglas Fir Region of the Pacific Coast (XI-2)

Status: Ongoing FY 76

Location: California and Oregon coasts

Principal Contact: WR-1 
Objective: To understand the processes and rates of erosion and to assess man's impact on these processes and rates.

Title: Levee Erosion Studies, Sacramento-San Joaquin Delta area, California (XI-3)

Status: Ongoing FY 76

Location: West-central California

Principal Contact: CA-1

Objective: To provide the California Department of Water Resources with information on erosive damage to levees caused by boat wakes.

Product:

Limerinos, J. T., and Smith, W., 1974, Evaluation of the causes of levee erosion in the Sacramento-San Joaquin Delta, California: U.S. Geol. Survey Water-Resources Inv. Rept. 28-74.

Title: Sediment-Transport Studies in Redwoods National Park, California (XI-4)

Status: Ongoing FY 76

Location: Northwestern California

Principal Contact: CA-1

Objective: To determine whether increased sediment and nutrient loading of the park may result from nearby lumbering operations.

Title: Digital Model of Loxahatchee River Environmental Control District (XI-5)

Status: Ongoing FY 76

Location: Southeast Florida

Principal Contact: FL-1

Objective: To determine the impact of a proposed sewage treatment facility on surface-water and ground-water systems. A digital model of the hydrologic system will be created to identify potential water-quality problems.

Title: Effects of Manmade Contaminants in Water Quality in the Central Florida Flood Control District and the South Florida Flood Control District System, Broward County (XI-6)

Status: Ongoing FY 76

Location: Southeast Florida

Principal Contact: FL-1

Objective: To provide water-quality and nutrient data which can be used by water management officials in evaluating the water resources of conservation areas.

Title: Effects of Manmade Contaminants in Water Resources of Broward County, Florida (XI-7)

Status: Ongoing FY 76

Location: Southeast Florida

Principal Contact: FL-1

Objective: To determine the nature and amount of contaminants in canals and the Biscayne aquifer in a highly urbanized area of southeast Florida. 
Title: Investigation of Contaminants in Storm-Water Runoff in Broward County, Florida (XI-8)

Status: Ongoing FY 76

Location: Southeast Florida

Principal Contact: FL-1

Objective: To determine the nature and amount of contaminants in stormwater runoff in a highly urbanized area of southeast Florida.

Title: Water Quality in the South New River Canal Basin, Florida (XI-9)

Status: Ongoing FY 76

Location: Southeast Florida

Principal Contact: FL-1

Objective: To determine the water quality of representative subbasins within the South New River Canal System.

Title: A Baseline Water-Quality Assessment of the Indiana Dunes National Shoreline (XI-10)

Status: Ongoing FY 76

Location: Northwest Indiana

Principal Contact: IN-1

Objective: To collect baseline data on chemical and bacteriological quality of water. Recommendations will be made to the National Park Service for Product: a water-quality monitoring program.

Arihood, L. D., 1975, Water-quality assessment of the Indiana Dunes National Lakeshore, 1973-74: U.S. Geol. Survey Water-Resources Inv. Rept. 14-75.

Title: Oxygen Cycle in Streams, Lakes, and Estuaries (XI-11)

Status: Ongoing FY 76

Location: Southern Mississippi

Principal Contact: MS-1

Objective: To study dissolved oxygen in surface waters in order to define the factors controlling those levels.

Title: Quality of Water Stations, New York (XI-12)

Status: Ongoing FY 76

Location: New York

Principal Contact: NY-1

Objective: To provide a national bank of water-quality data to provide average chemical concentrations, loads, and time trends as required by planning and management agencies.

Title: Quaternary Sedimentation at the Marine-Fluvial Interface (XI-13)

Status: Ongoing FY 76

Location: Southwest Oregon

Principal Contact: OR-1

Objective: To evaluate the processes governing erosion and sedimentation along Product: the southwestern Oregon coast.

Carlson, P. R., 1975, Principal sources and dispersion patterns of suspended particles in nearshore surface waters of the northeastern Pacific Ocean and the Hawaiian Islands: NTIS Rept. N75-22877, 145 p. 
Title: Modeling Waste Load Assimilation in Wisconsin (XI-14)

Status: Ongoing FY 76

Location: Wisconsin

Principal Contact: WI-1

Objective: To develop an oxygen computer model for streams at selected sewage-treatment plant sites in Wisconsin for regulatory, planning, and research purposes.

Title: Nemadji River Sediment Study (XI-15)

Status: Ongoing FY 76

Location: Northwest Wisconsin

Principal Contact: WI-1

Objective: To collect information on the amount, type, and chemical quality of sediment transported by the Nemadji River into Lake Superior.

Title: Sediment Transport in the Menomonee River Basin (XI-16)

Status: Ongoing FY 76

Location: Southeast Wisconsin

Principal Contact: WI-1

Objective: To collect data on the amount and character of stream-transported sediment throughout the Menomonee River basin.

\section{XII.-GENERAL HYDROLOGIC STUDIES}

Comprehensive regional or basinwide studies covering all phases of the hydrologic cycle are being conducted in many areas of the coastal zone. These studies are designed to provide the data, information, and methodology required to manage the water resources of a region or local area and to predict how these resources will respond to stresses placed upon them. In general, their purpose is to assess the water resources of a selected basin or region taking into account all forms of water in its passage through the hydrologic cycle from precipitation to surface flow to ground water and its return to the atmosphere by evapotranspiration. Accurate appraisals of all elements of the hydrologic cycle are stressed with emphasis placed on defining the interaction between ground water and surface water. A primary objective is to evaluate ground-water and surface-water quality by identifying and quantifying organic and inorganic constituents and thermal, sediment, and nutrient loading, as well as aquatic, biochemical, and trace element composition. Another objective of many of these broad-based projects is to interpret, analyze, and translate water data from many sources into products useful to water managers for the solution of specific problems. The products are usually in the form of reports published by the Geological Survey or by a cooperating agency.

Practically all comprehensive regional studies are made in highly urbanized areas and seek to identify man's impact on 
various parts of the hydrologic cycle. For example, in conjunction with other agencies in the Department of the Interior, the Geological Survey has published a report summarizing the effects on the environment of intensive urbanization in south Dade County, Florida. Urbanized and agricultural land uses have been rapidly replacing the original natural ecosystems. The resulting impact of greatly increased demand for water has created imbalances along freshwater-saltwater boundaries. These imbalances cause contamination of freshwater aquifers by landward moving salty water.

Some of the general hydrologic studies emphasize a particular bay or estuary. Intensive land changes for both urban and agricultural development have generated greatly increased contamination from sewage, sediment, nutrients, and toxic trace elements. The bulk of these contaminants are dumped directly into bays and estuaries or are borne by rivers and streams. In cooperation with HUD, the Geological Survey has undertaken a study of the environmental factors in the San Francisco Bay region related to urbanization.

\section{RELATED ACTIVITIES}

Title: Applications of Aerial Measurement Techniques (XII-1)

Status: Ongoing FY 76

Location: Nationwide

Principal Contact: WR-1

Objective: To apply airborne remote-sensing techniques to specific hydrologic problems such as circulation patterns, heat diffusion, and the detection of pollutants.

Title: General Hydrologic Research (XII-2)

Status: Ongoing FY 76

Location: Nationwide

Principal Contact: GA-1

Objective: To study the water balance of continental areas, with stress placed upon freshwater outflow to the oceans.

Products :

Nace, R. L., 1974, Environmental hazards of large-scale water developments, in Leversedge, F. M., Priorities in water management: Victoria, British Columbia, Canada, Victoria Univ., v. 18 , p. 3-18.

1974, Historical development of hydrology in North America, in UNESCO Contributions to the development of the hydrological cycle: Paris, UNESCO DOC. SC 74//CONF/COL 1, p. 9-23.

1974, Pierre Perrault: The man and his contribution to scientific hydrology: Water Resources Bull., v. 10, no. 4, p. 633-647.

1974, The hydrological cycle-historical evaluation of the concept, in UNESCO/WMO/IAHS, Three centuries of scientific hydrology: Paris, UNESCO, p. 41-51.

1975, Book review of World water balance and water resources of the Earth: Am. Geophys. Union, EOS, v. 5, no. 4, p. 251-252. 


\section{Title: National Water Data Exchange (NAWDEX) (XII-3)}

Status: Ongoing FY 76

Location: Nationwide

Principal Contact: WRD-1

Objective: To assist those needing water data in the identification, location, and acquisition of the data, a National Water Data Exchange (NAWDEX) will consist of water-oriented organizations throughout all levels of the Federal, State, and local governments, and private sectors of the water-data community. These organizations will work together to make their water data more readily available in a timely and efficient manner. All activities and services are coordinated by a central program office located within the U.S. Geological Survey. Assistance in the location of desired water data and the referral of requests to the most expedient source from which data can be acquired will be provided by the NAWDEX Program Office and a nationwide network of Local Assistance Centers established within the NAWDEX membership in nearly all States and major population centers. A computerized system is being established for a water Data Sources Directory containing information pertinent to the sources, location, types and availability of water data and for a Master Data Index containing more detailed information pertinent to the identification and definition of the types of water data held by NAWDEX members. Membership in NAWDEX is voluntary and open to those who wish to take an active role in its activities.

Product:

Mason, F. D., 1975, Support in the implementation of a national water data exchange (NAWDEX) : McLean, Va., PRC Systems Sciences Co., 240 p.

Title: Remote-Sensing Research in Wetlands (XII-4)

Status: Ongoing FY 76

Location: Nationwide

Principal Contact: WRD-1

Objective: To utilize high-altitude and satellite remote-sensing products to identify plant species and seasonal changes in wetland vegetation. Emphasis is placed on coastal wetlands.

Products:

Carter, Virginia, 1974, Remote-sensing applications to the Dismal Swamp: The Great Dismal Swamp Symposium, Old Dominion University, Norfolk, Va., Mar. 14, 1974, Proc., 34 p.

Carter, Virginia, and Schubert, Jane, 1974, Coastal wetlands analysis from ERTS MSS digital data and field spectral measurements: Internat. Symposium on Remote Sensing of Environment, 9th Ann Arbor, Mich. 1974, Proc., p. 1241-1260.

McEwen, R. B., Kosco, W. J., and Carter, Virginia, 1976, Coastal wetland mapping: Photogramm. Eng. and Remote Sensing, v. 42, no. 2, p. 221-232.

Title: Microwave Remote Sensing (XII-5)

Status: Ongoing FY 76

Location: Arctic Ocean; Lake Ontario, New York; and Gulf of St. Lawrence

Principal Contact: WR-1

Objective: Detection of ice with microwave-sensing equipment to provide precise and rapid detection of its areal extent. 
Title: Long Island Sound Regional Study (XII-6)

Status: Ongoing FY 76

Location: Long Island Sound, New York and Connecticut

Principal Contact: NY-1

Objective: To describe the ground-water, stream, and estuarine system of Long Island Sound and prepare these data in forms easily useable by decisionmakers in planning optimum uses of land and water resources.

Title: Water Resources of the Maumee River Basin, with Emphasis on the Fort Wayne, Indiana, Area (XII-7)

Status: Ongoing FY 76

Location: Northeast Indiana, southeast Michigan, and northwest Ohio

Principal Contact: IN-1

Objective: To evaluate existing water-resources data in the basin, and to identify water problems and suggest alternative water-supply sources.

Title: Geohydrology of the Anchorage Area, Alaska (XII-8)

Status: Ongoing FY 76

Location: Anchorage, Alaska

Principal Contact: AK-1

Objective: To inventory the area's water resources. Special attention will be given to determine if aquifer yields can be increased by use of artificial recharge.

Product:

Zenone, C., Donaldson, D. E., and Grunwaldt, J. S., 1975, Ground-water quality beneath solid-waste disposal sites at Anchorage, Alaska: Ground Water, v. 13 , no. 2, p. $182-190$.

Title: Hydrology of the Cordova Area, Alaska (XII-9)

Status: Ongoing FY 76

Location: Southeastern Alaska

Principal Contact: AK-1

Objective: To assist the city of Cordova in evaluating the ground-water potential of the area by applying geophysical-logging techniques to identify aquifers.

Title: Water Resources of the City and Borough of Juneau, Alaska (XII-10) Status: Ongoing FY 76

Location: Juneau, Alaska

Principal Contact: AK-1

Objective: To assess the availability of ground water and surface water for future development. Man's impact on water quality and quantity will be evaluated.

Product:

Balding, G. O., 1974, Hydrologic investigations of Salmon Creek Reservoir and drainage basin near Juneau, Alaska: U.S. Geol. Survey Admin. Rept. 2.

Title: Water Resources Investigation of the Kenai Peninsula Borough Area, Alaska (XII-11)

Status: Ongoing FY 76

Location: Kenai Peninsula, Alaska 
Principal Contact: AK-1

Objective: To evaluate the water-supply potential of the Kenai Peninsula Borough and man's impact on water resources. Data will be made available to assist water managers in operational decisions.

Title: Water Resources Investigations of the Valdez-Copper Center Area, South-Central Alaska (XII-12)

Status: Ongoing FY 76

Location: Alaska pipeline terminus

Principal Contact: AK-1

Objective: To make a hydrologic appraisal of water availability and quality as related to man's activities along the Alaska pipeline corridor from Valdez to Copper Center.

Title: San Francisco Bay Region Environment and Resource Planning Study Coordination (XII-13)

Status: Ongoing FY 76

Location: San Francisco Bay, California

Principal Contact: WR-1

Objective: To determine what earth-sciences data are needed by urban planners and to demonstrate the use of earth-sciences data and concepts in actual urban planning situations.

Title: San Francisco Bay Region Environmental Studies (XII-14)

Status: Ongoing FY 76

Location: San Francisco Bay Region

Principal Contact: CA-1

Objective: To provide assistance to planners, in solving problems related to floods, water supply, water use, erosional processes, and storm design criteria by using a multidisciplinary approach to water problems.

Products :

Carlson, P. R., and McCulloch, D. S., 1974, Aerial observations of suspended sediment plumes in San Francisco Bay and the adjacent Pacific Ocean: U.S. Geol. Survey, Jour. Research, v. 2, p. 519-526.

Conomos, T. J, 1975, Movement of spilled oil as predicted by estuarine nontidal drift: Limnology and Oceanography, v. 20, p. 159-173.

Conomos, T. J., and Peterson, D. H., 1974, Biological and chemical aspects of the San Francisco Bay turbidity maximum: Institut de Géologie du Bassin d'Aquitaine Mem., no. 7, p. 45-52.

-1974, Movement of spilled oil in San Francisco Bay as predicted by estuarine nontidal drift, in Marine Pollution Monitoring (Petroleum), Symposium proceedings, May 1974, Gaithersburg, Md.: National Bureau of Standards Pub. 409, p. 97-100.

Peterson, D. H., Conomos, T. J., Broenkow, W. W., and Doherty, P. C., 1975, Location of the nontidal current null zone in northern San Francisco Bay: Estuarine and Coastal Marine Sci., v. 3, p. 1-11.

Peterson, D. H., Conomos, T. J., Broenkow, W. W., and Scrivani, E. P., 1975, Processes controlling the dissolved silica distribution in San Francisco Bay, in Cronin, L. E., ed., Estuarine research-chemistry and biology: Academic Press, v. 1, p. 153-187. 
Title: Environmental and Resource Demonstration Study of the Connecticut Valley Urban Area (XII-15)

Status: Ongoing FY 76

Location: Connecticut Valley

Principal Contact: CT-1

Objective: To demonstrate how hydrologic data can be used in urban planning, what types of hydrologic data are most useful, and what the relation of such data is to current and planned zoning.

Title: Water Resources of the Lower Connecticut River Basin (XII-16)

Status: Ongoing FY 76

Location: Lower Connecticut River basin

Principal Contact: CT-1

Objective: To investigate the water resources of the lower Connecticut River basin.

Product:

Bingham, J. W., Paine, F. D., and Weiss, L. A., 1975, Hydrogeologic data for the lower Connecticut River basin, Connecticut: Connecticut Water Resources Bull. no. 30.

Title: An Evaluation of the Water Resources in Duval and Nassau Counties, Florida (XII-17)

Status: Ongoing FY 76

Location: Northeast Florida

Principal Contact: FL-1

Objective: To evaluate the potential of all water resources in the area that can be used in the future and to monitor changes in the quality and quantity of ground water and surface water.

Title: Effects of Urbanization on Hydrologic Parameters at Jacksonville, Florida (XII-18)

Status: Ongoing FY 76

Location: Northeast Florida

Principal Contact: FL-1

Objective: To evaluate available information on streamflow, ground water, and near-surface geology. The data will be used to show areas where little or no change in the hydrology should be made in order to protect water supplies.

Title: Geohydrologic Study of a Landfill and Septic Tank Effluent Operation in a Coastal Limestone Environment, St. Petersburg, Pinellas County, Florida (XII-19)

Status: Ongoing FY 76

Location: West-central Florida

Principal Contact: FL-1

Objective: To determine the effects on water resources of solid-waste disposal and septic-tank effluent in a coastal area with a high water table.

Title: Hydrologic Base for Water Management, Dade County, Florida (XII-20)

Status: Ongoing FY $\mathbf{7 6}$

Location: Miami, Florida 
Principal Contact: FL-1

Objective: To summarize hydrologic conditions in Dade County as urbanization continues and to assist local agencies in specific water-management problems.

Title: Hydrology of Western Collier County, Florida (XII-21)

Status: Ongoing FY 76

Location: Southwest Florida

Principal Contact: FL-1

Objective: To determine the locations which would most likely yield the greatest quantities of high-quality water to supply the ultimate municipal needs of western Collier County.

Title: Miami Canal Infiltration (XII-22)

Status: Ongoing FY 76

Location: Southeastern Florida

Principal Contact: FL-1

Objective: To evaluate the value of corrective measures to improve infiltration from the canal. The recharge capacity of the freshwater portion of the canal must be increased to prevent saltwater contamination of nearby well fields.

Title: Water Resources of Broward County, Florida (XII-23)

Status: Ongoing FY 76

Location: Southeast Florida

Principal Contact: FL-1

Objective: To monitor the movement, storage, and quality of the groundwater and surface-water systems in this urbanizing area. The effects of such factors as sewage and pumping on water resources will be evaluated.

Title: Water Resources of Lee County, Florida (XII-24)

Status: Ongoing FY 76

Location: Southwest Florida

Principal Contact: FL-1

Objective: To define the nature and extent of man's impact on water supplies in Lee County. Rapid urbanization has increased the magnitude and complexity of problems related to water use, floods, and saltwater contamination of aquifers.

Title: Water Resources in the Waccasassa River Basin, Florida (XII-25)

Status: Ongoing FY 76

Location: West north-central Florida

Principal Contact: FL-1

Objective: To describe the basin's water resources using all available published and unpublished data.

Title: Early Warning for and Evaluation of Effects on National Park Service Property of Proposed Dewatering at NIPSCO's Bailly \#1 Construction Site (XII-26)

Status: Ongoing FY 76

Location: Northwest Indiana

Principal Contact: IN-1

Objective: To assess whether dewatering operations of the site for a nuclear powerplant may adversely affect the water resources of a national park. 
Title: Status of Hydrologic Conditions-Baton Rouge Area (XII-27)

Status: Ongoing FY 76

Location: Southeast Louisiana

Principal Contact: LA-1

Objective: To determine the adequacy of ground-water resources to meet expanding demands. Ground water is the principal water source for public supplies, whereas surface water is used by industry, especially along the Mississippi.

Title: Status of Hydrologic Conditions-New Orleans Area (XII-28)

Status: Ongoing FY 76

Location: Southern Louisiana

Principal Contact: LA-1

Objective: To monitor the water-level declines and saltwater encroachment of selected aquifers.

Title: Water Resources of the Coastal Basins of Southeastern Massachusetts (XII-29)

Status: Ongoing FY 76

Location: Southeast Massachusetts

Principal Contact: MA-1

Objective: To provide information on the quality and quantity of water that is available to meet the future water needs of towns, cities, and industry.

Title: Geology and Hydrology for Environmental Planning in Michigan (XII-30)

Status: Ongoing FY 76

Location: Michigan

Principal Contact: MI-1

Objective: To describe the geologic and hydrologic resources of selected counties so that land use alternatives with regard to water resources can be evaluated.

Product:

Fleck, W. B., 1974, Geology and hydrology for environmental planning in Washtenaw County, Michigan: Mich. Geol. Survey, Environmental Geology Series Rept. 1.

Title: Water Resources of River Basins in Southeastern Michigan (XII-31) Status: Ongoing FY 76

Location: Southeast Michigan

Principal Contact: MI-1

Objective: Streamflow data and information on dams and lakes will be summarized in basin gazetteers and hydmologic atlases. The impact of alternative waste-water management systems on the ground-water reservoir will be assessed.

Product:

Twenter, F. R., Knutilla, R. L., and Cummings, T. R., 1974, Water resources of basins for minor streams draining into St. Clair River, Lake St. Clair, Detroit River and Lake Erie, Southeastern Michigan: U.S. Geol. Survey Hydrol. Inv. Atlas HA-546. 
Title: Environmental Impact Assessment of Copper-Nickel Mining Development in Northeastern Minnesota (XII-32)

Status: Ongoing FY 76

Location: Northeast Minnesota

Principal Contact: $\mathrm{MN}-1$

Objective: To describe the hydrology of the area in order to obtain baseline information. An assessment of the copper-nickel mining operation on the area's water resources will then be made.

Title: Hydrology of Watersheds in the Lake Superior Basin (XII-33)

Status: Ongoing FY 76

Location: Northeast Minnesota

Principal Contact: $\mathrm{MN}-1$

Objective: To assess data on the availability of surface-water and groundwater, quality, and water usage for municipal, industrial, agricultural, and recreational development.

Title: Water for Industrial Development in George, Hancock, Pearl River, and Stone Counties, Mississippi (XII-34)

Status: Ongoing FY 76

Location: Southern Mississippi

Principal Contact: MS-1

Objective: To determine the location, depth, and yield of aquifers, "dependable" flow of streams, the quality of water in streams and aquifers, and the potential for water supply from streams.

Title: Selection and Appraisal of Storm-Water Recharge Basins for Supplemental Recharge of Highly Treated Sewage in Nassau County, Long Island (XII-35)

Status: Ongoing FY 76

Location: Long Island, New York

Principal Contact: NY-1

Objective: To assess the suitability of the county's network of recharge basins to use their unused capacity to increase recharge rates.

Title: Snow Hydrology and Soil Moisture, Lake Ontario (XII-36)

Status: Ongoing FY 76

Location: Lake Ontario basin, New York

Principal Contact: NY-1

Objective: To determine the manner, rate, and infiltration to the soil during snowmelt periods, and the volume of water retained as soil moisture storage.

Title: Survey of Hydrogeology and Water Quality of That Part of Southeast Nassau County to be Served by Wantagh Sewage Treatment Plant (XII-37)

Status: Ongoing FY 76

Location: Long Island, New York

Principal Contact: NY-1

Objective: To gather hydrologic, water quality, and precipitation data before completion of sewering. 
Title: Water Resources of the South Fork of Long Island, New York (XII-38)

Status: Ongoing FY 76

Location: Long Island, New York

Principal Contact: NY-1

Objective: To describe the occurrence and movement of freshwater on the South Fork by investigating the interaction of surface-water and groundwater systems.

Title: Effect of Land Clearing and Drainage on Hydrology of the AlbemarlePamlico Area (XII-39)

Status: Ongoing FY 76

Location: Northeast North Carolina

Principal Contact: NC-1

Objective: To determine the extent to which the water balance and water quality of runoff are changed by land clearing and drainage activities.

Product:

Heath, R. C., 1975, Hydrology of the Albemarle-Pamlico region, North Carolina-a preliminary report on the impact of agricultural developments: U.S. Geol. Survey Water-Resources Inv. 9-75, 98 p.

Title: Water Resources Potential of Northeast North Carolina Above Cape Lookout (XII-40)

Status: Ongoing FY 76

Location: Northeast North Carolina

Principal Contact: NC-1

Objective: To prepare a hydrologic appraisal of the water resources of the area with special emphasis on water problems such as floods and saltwater encroachment.

Title: Water Resources Appraisal, Lincoln County Coast, Oregon (XII-41) Status: Ongoing FY 76

Location: West-central Oregon

Principal Contact: OR-1

Objective: To appraise the availability and quality of ground water and surface water with special reference to urbanization and water limitation.

Title: Cooper River Rediversion (XII-42)

Status: Ongoing FY 76

Location: Southeast South Carolina

Principal Contact: SC-1

Objective: To monitor and evaluate changes in siltation in Charleston Harbor stemming from the rediversion of Cooper River flow into the Santee River.

Product:

Spiers, C. A., 1974, Preliminary report of the effect of the Cooper River Rediversion Canal on the ground-water regimen of the St. Stephens area: U.S. Geol. Survey Admin. Rept., 53 p.

Title: Water Resources of the Tulalip Reservation (XII-43)

Status: Ongoing FY 76

Location: Northwestern Washington 
Principal Contact: WA-1

Objective: To provide technical information concerning the water resources of the reservation in terms of quality and areal distribution which will assist the Tulalip Indians in water-supply management.

Title: Departmental Planning and Great Lakes Hydrology (XII-44)

Status: Ongoing FY 76

Location: Madison, Wisconsin

Principal Contact: WI-1

Objective: To guide Geological Survey field offices in project planning for the Great Lakes Basin.

Title: Hydrology of the Menomonee River Basin (XII-45)

Status: Ongoing FY 76

Location: Southeast Wisconsin

Principal Contact: WI-1

Objective: To investigate ground-water occurrence and availability, waterpollution sources, sediment transport in streams, and the oxygen available in the river.

Title: Hydrology of Wetlands in Wisconsin (XII-46)

Status: Ongoing FY 76

Location: Wisconsin

Principal Contact: WI-1

Objective: To study the effects of wetlands on runoff, sedimentation, and the chemical nature of streams and lakes and to define the relation of wetlands to ground water.

\section{XIII.-EARTH- AND OTHER NATURAL-SCIENCE APPLICATION STUDIES}

The purpose of these studies is to develop and evaluate data and information products; techniques, and methodologies which can provide assistance to land use and natural resources planners and decisionmakers at all levels of government, and the private sector. Four discipline areas receive the greatest emphasis in these studies: urban geohydrology, natural science, geography, and cartography. The thrust of many of these studies is to provide insight into the environmental implications of alternative proposals for land and resources use. Study products are specifically designed to be understood and utilized by land use planners and decisionmakers who require natural resources information. Many of these individuals have had varying amounts of natural resources training, yet they are being increasingly involved in issues concerning the use of land and resources. They often require interpretive data products to facilitate their use of this information.

The successful completion of these application-oriented studies requires input from the scientific, planning, and decisionmaking 
communities. The basic perspectives of producers of natural resources information and the community of users of such information may differ. The products of these studies have been and can be used in formulating land use ordinances, drafting natural hazards reduction legislation, developing facilities-siting policies and methodologies, in the identification and management of critical areas, and in the development of natural resources information systems.

Urban geohydrologic studies are concerned with the severe demands imposed by urbanization and development on land and water resources in rapidly growing metropolitan areas. Land and water use allocations in these high-demand areas can be most effectively met with the application of technically sound geohydrologic data to assist planning and decisionmaking groups. Geohydrologic topics of concern include water-supply sources and their physical, chemical, and biological composition, waste-water treatment issues, erosion and sediment transport, sources of construction materials, and the identification of geologic, soils, and hydrologic constraints to intensive land uses, among others. The objective of these studies is to explore alternative techniques of collecting, interpreting, and displaying earth-science data to a nontechnical user group.

The principal products of the urban geohydrologic studies are single-factor basic-data maps which display the spatial distribution of various geologic and hydrologic characteristic and facts, including depth to bedrock, slope, thickness of unconsolidated deposits, landslide susceptibility, location of aquifers, productivity of aquifers, chemical quality of ground and surface waters, floodprone areas, potentially valuable metallic and nonmetallic minerals deposits, depth to ground water, seasonal wetlands, and many others In addition, interpretive reports, from which the singlefactor maps were derived, are published as well as others which evaluate the utility of the data maps to land use planners and decisionmakers. Scales of maps range from 1:500,000 for regional areas to $1: 24,000$ for local areas. The common regional-scale map for the San Francisco Bay region study, for example, is $1: 125,000$.

Many natural resources planning issues are multidisciplinary in nature, and require for their resolution information from many fields, including the natural sciences, life sciences, economics, sociology, law, and data processing. The field of comprehensive natural resources planning is relatively new, and many individual practitioners were trained in some other field or in a single discipline. Communications links between planning 
groups at all levels of government and in the private sector are often not highly developed. A common body of needs or issues of this group is emerging as the profession evolves. One of these needs pertains to the development, application, evaluation, and transfer of methodologies for such land planning purposes as the siting of powerplants, utility corridor location, siting the onshore facilities required by offshore energy development, State land resource inventory programs, and environmental impact assessment. Methodological studies have been completed or are currently underway which take a five-phase approach to these topics. This approach consists of: (1) a bibliographic search of available literature and methodologies; (2) methodology development, if required; (3) case-study application of methodology; (4) evaluation and revision of phases 2 and 3 ; and (5) transfer of knowledge developed in phases 1-4 through publications, workshops, and symposia. It is hoped that this process can make a contribution to planning techniques in both terms of review and dissemination of what has already been accomplished and also as an extension of the state of the art.

Another need in the natural resources planning field is improved communication between the producers of data, who are often Federally oriented, and the data users, who often have a State or local orientation. Studies have been started to identify and evaluate the utility to the State and local planning community of selected data and information products. Work is underway to produce a national product-evaluation survey and to conduct a series of workshops, attended by Federal and State representatives, to discuss data-product deficiencies, and to identify data and information gaps and procedures to alleviate them.

A prerequisite for competent decisions concerning natural resource use is access to existing information. Much natural resources information within the Department of the Interior is not readily accessible. Much data of great potential utility have not been cataloged or documented in such a way as to facilitate their wide dissemination. Projects are currently underway to develop and disseminate secondary information products to serve as directories to Department of the Interior data holdings, information systems, and data bases, and ongoing and completed research efforts.

The Geological Survey is currently engaged in a nationwide land use and land cover mapping and data compilation effort. The coastal zone has been given priority in production scheduling of land use maps (Fig. 14). The maps overlay the 1:250,000- 


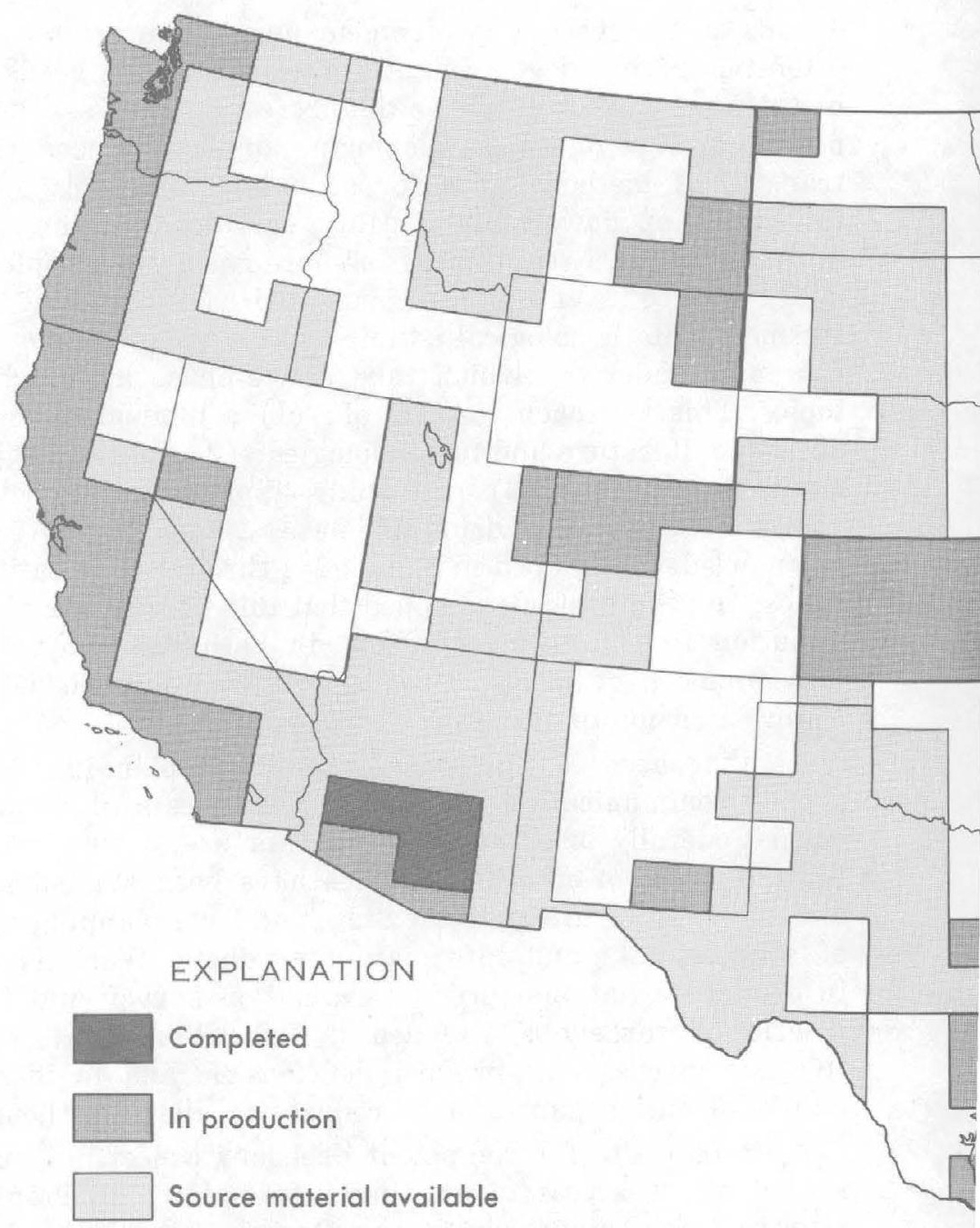

Fairbanks, Alaska sheet-In production

FIGURE 14.-Land use/land cover map production.

scale standard topographic series, which is being used as the mapping base. Land use and land cover is categorized according to the classification presented in U.S. Geological Survey Professional Paper 964. All urban and built-up features, feed lots, water surfaces, and strip mines, quarries, and gravel pits are being mapped using 10-acre (4-hectare) minimum mapping units, while other land features are being mapped in 40-acre (10-hectare) 


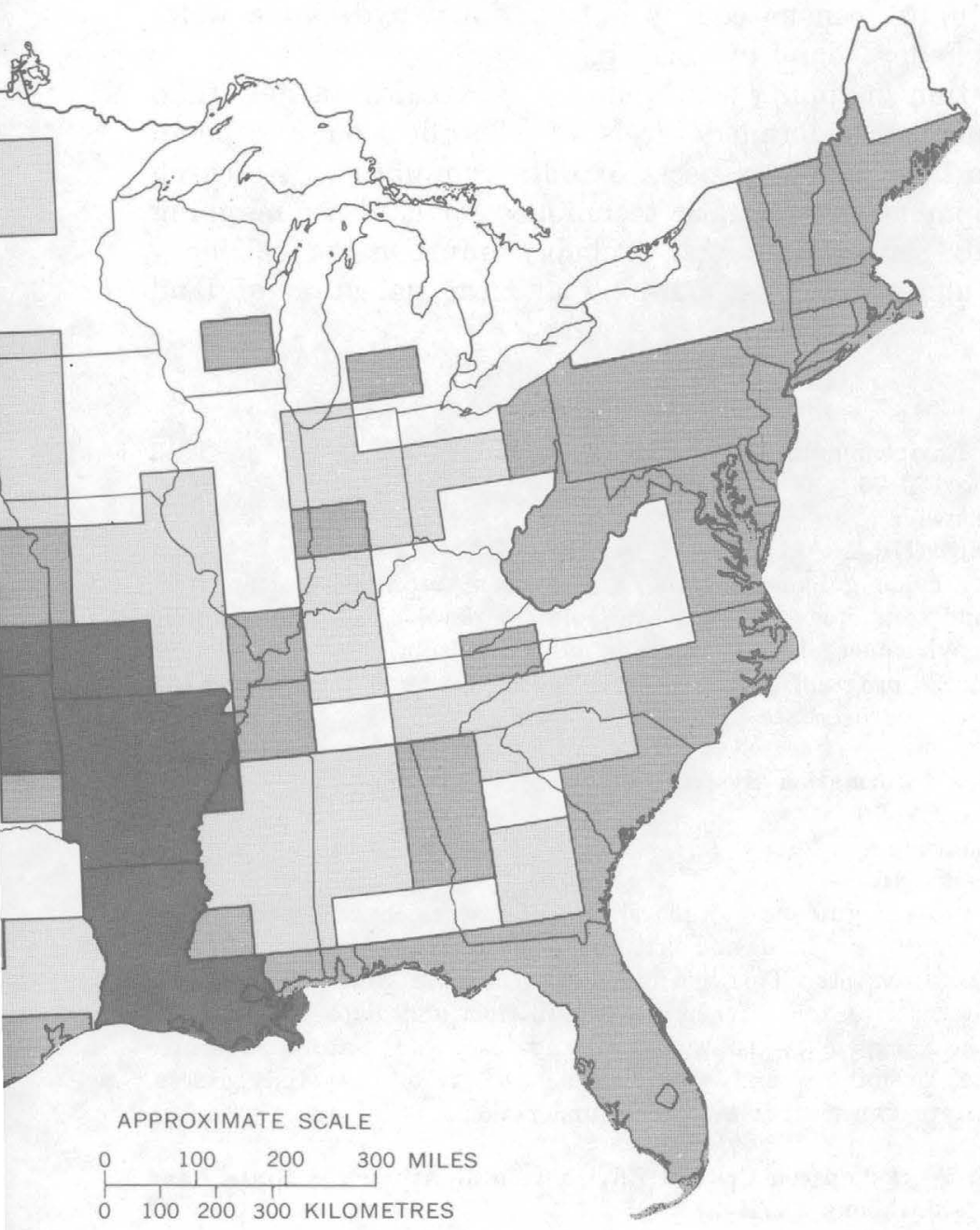

minimum mapping units. The land use and land cover information is available in map format after compilation and on digital tapes after digitizing in order to facilitate handling of land use data in conjunction with other data sets for the study of problems related to land use. Computer programs for geographic information systems are being developed to support land use data processing, as well as techniques for the handling and overlay of other information, such as census data, with the digitized land use data sets. Summary tabulations of land use are produced 
for political units, census county subdivisions, hydrologic units and areas of Federal land ownership.

Demonstration mapping of land use at scales larger than $1: 250,000$ and more detailed levels of classification are being performed to test various aspects of data compilation. Research in the development of automatic techniques for land use mapping from remotely sensed data will probably improve the efficiency of land use and land cover mapping and the detection of land use change.

\section{RELATED ACTIVITIES}

Title: Critical Environmental Areas Guidebook (XIII-1)

Status: Ongoing FY 76

Location: Nationwide

Principal Contact: NR-5

Objective: To provide guidance to the States about alternative definitions, methods, and techniques that are available for developing and managing a critical environmental area program. Issues and options for developing a critical areas program are being investigated, along with several casestudy evaluations of State approaches.

Title: Land Use Information Systems Guidebook (XIII-2)

Status: Ongoing FY 76

Location: Nationwide

Principal Contact: NR-5

Objective: To provide guidance to individual States which will assist them in determining their land and natural resource information and data handling requirements. This is intended to enable States to consider feasible alternatives for information acquisition and data handling, to enhance their capability to support land use and natural resource planning responsibilities and policy decisions. Several case-study assessments of State experiences are being undertaken.

Title: Regional Workshops on Critical Environmental Areas and State Land Inventory Guidebooks (XIII-3)

Status: Ongoing FY 76

Location: Nationwide, with regional meetings in Atlanta, Boston, Chicago, Denver, San Francisco, and Washington, D.C.

Principal Contact: NR-5

Objective: To have State planners review critically two methodological guidebooks, one on critical areas and the other on State and land inventory systems, at a series of six regional workshops. The workshops are designed for technology transfer to insure the information in the guidebooks reaches the audience for whom they were designed.

Title: Land Use Mapping and Data Compilation at 1:125,000-Scale (XIII-4) Status: Ongoing FY 76

Location: Nationwide Gulf, Atlantic, and Pacific coastal area will be given priority in FY 76.

Principal Contact: NR-2 
Objective: To inventory current land use and land cover, and to provide an update on this material every 5-10 years. Aerial photographs, satellite images, and maps are used to compile land use maps which are digitized, along with other data, such as boundaries of States, counties, census subdivisions, Federal ownership areas, and drainage basins.

Product:

Anderson, J. R., Hardy, E. E., Roach, J. T., and Witmer, R. E., 1976, A land use classification system for use with remote sensor data: U.S. Geol. Survey Prof. Paper 964, 28 p.

Title: Methodologies for Environmental Analysis (XIII-5)

Status: Completed FY $\mathbf{7 5}$

Location: Nationwide

Principal Contact: NR-5

Objective: To produce a set of documents which presents current techniques of environmental planning and analysis. Three areas were of concern: Environmental assessment, utility corridor selection, and powerplant siting. Each volume presents an overview of the basic techniques in use, a review of relevant regulatory and legislative requirements, and an annotated bibliography of pertinent documents.

Products :

Bennington, G., Lubore, S., and Pfeffer, J., 1974, Methodologies for environmental analysis, V. I, Environmental assessment: McLean, Va., The MITRE Corp., 160 p. Prepared for U.S. Geological Survey under contract No. 14-08-0001-14715.

Graf-Webster, E., Lubore, S., and Pfeffer, J., 1974, Methodologies for environmental analysis, V. I, Utility corridor selection: McLean, Va., The MITRE Corp., 84 p. Prepared for U.S. Geological Survey under contract No. 14-08-0001-14715.

Graf-Webster, E., Haus, S., Pfeffer, J., and Watson, J., 1974 Methodologies for environmental analysis, V. III, Power plant siting: McLean, Va., The MITRE Corp., 449 p. Prepared for U.S. Geological Survey under contract No. 14-08-0001-14715.

Title: Utility Corridor Study (XIII-6)

Status: Completed FY 75

Location: Nationwide

Principal Contact: NR-5

Objective: To investigate factors and methods of assessing the impacts of utility corridor proposals. Siting issues are considered for corridors and rights-of-way for electric power transmission lines and pipelines through which energy commodities of all types (gases, liquids, and slurry) flow. Case-study evaluations are made of utility corridor route location methodologies and their applications.

Product :

Holberger, R., Lubore, S., Morrow, L., Watson, J., and Williams, F., 1975, Resource and land investigations (RALI) program: Considerations in evaluating utility line proposals: McLean, Va., The MITRE Corp., 347 p. Prepared for the Bureau of Land Management with U.S. Geological Survey support under contract No. 08550-CT5-3. 
Title: Council of State Governments Task Force (VIII-7)

Status: Completed FY 75

Location: Nationwide

Principal Contact: NR-5

Objective: To study State land use programs and policies by the Task Force on Natural Resource and Land Use Information and Technology, appointed by the Council of State Governments.

Products:

Council of State Governments, 1974, Land use management, proceedings of the national symposium on resource and land information: Lexington, Ky., Council of State Governments, $127 \mathrm{p}$.

Task Force on Natural Resources and Land Use Information and Technology, 1975, Land, State alternatives for planning and management: Lexington, Ky., Council of State Governments, 100 p.

- 1975, Land use policy and program analysis, number 1, Intergovernmental relations in state land use planning: Lexington, Ky., Council of State Governments, $40 \mathrm{p}$.

,- 1975 , Land use policy and program analysis, number 2, Data needs and resources for state land use planning: Lexington, Ky., Council of State Governments, 35 p.

$\longrightarrow, 1975$, Land use policy and program analysis, number 3, Organization, management, and financing of State land use programs: Lexington, Ky., Council of State Governments, $84 \mathrm{p}$.

,- 1975 , Land use policy and program analysis, number 4, State-of-theart for designation of areas of critical environmental concern: Lexington, Ky., Council of State Governments, 52 p.

—_ 1975, Land use policy and program analysis, number 5, Issues and recommendations-State critical areas programs: Lexington, Ky., Council of State Governments, $45 \mathrm{p}$.

,- 1975 , Land use policy and program analysis, number 6, Manpower needs for State land use planning, and public involvement in State land use planning: Lexington, Ky., Council of State Governments, 30 p.

Title: Product Evaluation Project (XIII-8)

Status: Completed FY 76

Location: Nationwide

Principal Contact: NR-5

Objective: To design and initiate a feedback process between selected State land and natural resource data users and the Geological Survey. The Council of State Governments, as the contractor, canvassed State data users to determine: (1) the usability to these persons of a number of selected Federally prepared data products; (2) the current use of natural resource data by these users; and (3) the best means for continuing a product evaluation feedback mechanism that would facilitate communication between State users and Federal producers of data.

Product:

Council of State Governments, 1976, Natural resource data needs recommendations: Lexington, Ky., Council of State Governments, 25 p.

Title: Coordinating State and Federal Data Programs: Product Evaluation Workshops (XIII-9)

Status: Ongoing FY 76 
Location: Nationwide

Principal Contact: NR-5

Objective: The results of the Product Evaluation Project (XIII-8) performed by the Council of State Governments will be used as the basis for a series of workshops involving State land use and resource planners and Federal data producers. The workshop will provide the forum for the exchange of information, ideas, and issues faced by data producers (largely at the Federal level) and data users (largely at the State and regional levels) relating to the use of these data in solving land and resource probems. It is anticipated that out of these workshops a plan for systematic communications with State agencies and the evaluation of new products, systems, and sources, will emerge.

Title: Department of the Interior Information Services Directory (XIII-10) Status: Ongoing FY 76

Location: Nationwide

Principal Contact: NR-5

Objective: To provide, for Federal, State, and local land use and resource planners, a guide to the information services of the Department of the Interior. Much information currently exists in the Department but a guide is presently lacking which will assist the generalist who needs a broad spectrum of data on water, geology, mines, fish and wildlife, remote sensing, public lands, reclamation, hydroelectric resources, Tribal activities, and other areas of Departmental activity.

Title: Mined Area Reclamation and Related Land Use Planning (XIII-11)

Status: Ongoing FY 76

Location: Nationwide

Principal Contact: NR-5

Objective: To prepare a report which summarizes, for land and resource planners, the processes, methodologies, and alternative choices that arise as land is converted to surface mining and is later reconverted into an asset or is left as a liability. The report will be based on a literature review and study of representative case studies. The methodology will assist planners in the integration of land use plans with mining and

Product: reclamation plans.

Imhoff, E. A., Friz, T. O., and LaFevers, J. R., 1976, A guide to State programs for the reclamation of surface mined areas: U.S. Geol. Survey Circ. 731,33 p.

Title: National Environmental Statistical Report (XIII-12)

Status: Completed FY 75

Location: Nationwide

Principal Contact: NR-5

Objective: To provide a single source of generalized environmental data. About 200 tables have been compiled which provide data on characteristics such as air and water quality, pesticides, land use, energy, food, and transportation, among others. The data are organized principally by State, but some information is presented by watershed or standard metropolitan statistical area. 
Title: Development and Application of a Methodology for Siting Onshore Facilities Associated with Outer Continental Shelf Energy Development (XIII-13)

Status: Ongoing FY 76

Location: Maine, New Hampshire, Massachusetts, Rhode Island, and Connecticut

Principal Contact: NR-5

Objective: To develop a methodology to assist the States in planning for the onshore facilities anticipated from Outer Continental Shelf energy development. It is done under contract with the New England River Basins Commission. The methodology will include, as major components, the development of (1) energy resource scenarios; (2) estimates of numbers and kinds of required onshore energy facilities; (3) a siting procedure for the generation of alternative siting policies and strategies; and (4) the data and information requirements for sound siting decisions. The methodology will then be applied in the New England States and the experience of that application will be used for its refinement and transfer to other States experiencing OCS energy development.

\section{Title: Census Cities Project (XIII-14)}

Status: Ongoing FY 76

Location: California, Massachusetts, Washington, and the District of Columbia

Principal Contact: NR-2

Objective: To test the utility of satellite data and aerial photographs in mapping land use and land use changes around the cities of San Fran-

Product: cisco, Boston, Seattle, and Washington, D.C.

Wray, J. R., 1974, Folio of land use in the Washington, D.C., urban area: U.S. Geol. Survey Map Folio I-858, scale 1:100,000, 3 p.

Title: Central Atlantic Regional Ecological Test Site (XIII-15)

Status: Ongoing FY 76

Location: Virginia, Maryland, Delaware, New Jersey, and Washington, D.C. Principal Contact: NR-2

Objective: To test the utility of NASA satellite images and aerial photographs in mapping land use, as well as, geologic and hydrologic information. Both current land use and changes in land use are being mapped.

\section{Title: Baltimore-Washington Urban Area Study (XIII-16)}

Status: Ongoing FY 76

Location: Baltimore-Washington, D.C., area

Principal Contact: NR-3

Objective: To provide earth-science information needed by land use planners and decisionmakers in the National Capital area so that their choices among alternative land use possibilities consider the natural resources and hazards of the area.

Products:

Cleaves, E. T., Crowley, W. P., and Kuff, K. R., 1974, Towson quadrangle geologic and environmental atlas: Maryland Geological Survey, five maps, scale $1: 24,000$.

Froelich, A. J., 1975, Surface materials map of Montgomery County, Maryland: U.S. Geol. Survey Misc. Inv. Map I-920-A, scale 1:62,500. 
1975, Thickness of overburden map of Montgomery County, Maryland: U.S. Geol. Survey Misc. Inv. Map I-920-B, scale 1:62,500.

, 1975, Map showing contours on base of saprolite, Montgomery County, Maryland: U.S. Geol. Survey Misc. Inv. Map I-920-C, scale $1: 62,500$.

- , 1975, Bedrock map of Montgomery County, Maryland: U.S. Geol. Survey Misc. Inv. Map I-920-D, scale 1:62,500.

- 1975, Mineral resources map of Montgomery County, Maryland: U.S. Geol. Survey Misc. Inv. Map I-920-E, scale 1:62,500.

Glaser, J. D., 1973, Bowie quadrangle, geologic and environmental atlas: Maryland Geological Survey, four maps with text, scale 1:24,000.

Hack, J. T., and Froelich, A. J., 1974, Geology and soils in the Washington, D.C., area (abs.): Geol. Soc. America Abs. with Programs, v. 5, no. 1, p. 32-33.

Withington, C. F., and Froelich, A. J., 1974, Preliminary geologic map of the Beltsville quadrangle, Prince Georges, Montgomery, and Howard Counties, Maryland: U.S. Geol. Survey Misc. Field Studies Map MF-582.

Title: San Francisco Bay Region Study (XIII-17)

Status: Ongoing FY 76

Location: San Francisco Bay area

Principal Contact: CA-4

Objective: To demonstrate the application of earth-science information to regional planning needs. The San Francisco Bay region, selected for study jointly by the Geological Survey and the Department of Housing and Urban Development as a pilot study area, has special relevance because of its rapid population growth and its broad spectrum of natural hazards including landslides, earthquakes, and floods.

Products:

Blake, M. C., Jr., and others, 1974, Preliminary geologic map of Marin and San Francisco Counties, and parts of Alameda, Contra Costa, and Sonoma Counties, Calif.: U.S. Geol. Survey Misc. Field Studies Map MF-574, scale $1: 62,500$.

Borcherdt, R. D., ed., 1975, Studies for seismic zonation of the San Francisco Bay region: U.S. Geol. Survey Prof. Paper 941-A.

Frizzell, V. A., Jr., 1974, Reconnaissance photointerpretation map of landslides in parts of the Hopland, Kelseyville, and Lower Lake 15-minute quadrangles, Sonoma County, Calif.: U.S. Geol. Survey Misc. Field Studies Map MF-594, scale 1:62,500.

Frizzell, V. A., Jr., Sims, J. D., Nilsen, T. H., and Bartow, J. A., 1974, Preliminary photointerpretation map of landslide and other surficial deposits of the Mare Island and Caroline Strait 15-minute quadrangles, Contra Costa, Marin, Napa, Solano, and Sonoma Counties, Calif.: U.S. Geol. Survey Misc. Field Studies Map MF-595, scale 1:62,500.

Goss, Joseph, 1974, Availability of data on surface water quantity and quality in the San Francisco Bay region, Calif., with a summary of beneficial uses and implications for land use: U.S. Geol. Survey Misc. Field Studies Map MF-526, scale 1:250,000.

Hall, N. T., Sarna-Wojcizki, A. M., and Dupre, W. R., 1974 [1975], Faults and their potential hazards in Santa Cruz County, Calif.: U.S. Geol. Survey Misc. Field Studies Map MF-626, scale 1:62,500. 
Lajoie, K. R., Helley, E. J., Nichols, D. R., and Burke, D. B., 1974, Geologic map of unconsolidated and moderately consolidated deposits of San Mateo County, Calif.: U.S. Geol. Survey Misc. Field Studies Map MF-575, scale 1:62,500.

Nichols, D. R., and Buchanan-Banks, J. M., 1974, Seismic hazards and land use planning: U.S. Geol. Survey Circ. 690, 33 p.

Radbruch, D. H., and Crowther, K. C., 1974, Map showing areas of estimated relative amounts of landslides in California: U.S. Geol. Survey Misc. Inv. Map I-747, scale 1:500,000.

Radbruch-Hall, D. H., 1974 [1975], Map showing recently active breaks along the Hayward fault zone and the southern part of the Calaveras fault zone, California: U.S. Geol. Survey Misc. Inv. Map I-813, scale 1:24,000.

Sorg, D. H., and McLaughlin, R. J., 1975, Geologic map of the SargentBerrocal fault zone between Los Gatos and Los Altos Hills, Santa Clara County, Calif.: U.S. Geol. Survey Misc. Field Studies Map MF-643, scale $1: 24,000$.

Title: Connecticut Valley Urban Area Study (XIII-18)

Status: Ongoing FY 76

Location: Connecticut Valley

Principal Contact: CT-2

Objective: To demonstrate, for areas of diverse topographic, geologic, and hydrologic conditions, the importance, necessity, and usefulness of incorporating adequate knowledge of earth resources into regional planning for solving urban growth problems related to the development and management of land and water resources. To present fundamental scientific knowledge of earth processes and resources in new formats that will be easily understandable and readily useable by decisionmakers with nontechnical backgrounds. The Connecticut Valley area was selected for study because (1) it represents a glaciated area (one of the complex geologic terrains addressed by the urban area studies) within the densely populated "northeast corridor," (2) it faces major problems and decisions with respect to planning for urban growth and use of water and land for such conflicting purposes as solid-waste disposal, liquid-waste disposal, industrial development, sources of construction materials, and water supply, and (3) the current availability of up-todate data collected by the State of Connecticut and by the Connecticut Cooperative Geologic Program (III-7) would allow rapid progress in providing planners with information needed to resolve problems.

Products :

Bingham, J. W., 1975, Contour map of the bedrock surface, Middletown quadrangle, Connecticut: U.S. Geol. Survey Misc. Field Studies Map MF$639-B$, scale $1: 24,000$.

Brown, C. E., 1974, Contour map of the bedrock surface, Branford quadrangle, Connecticut: U.S. Geol. Survey Misc. Field Studies Map MF$560-\mathrm{C}$, scale $1: 24,000$.

- , 1974, Resources of coarse aggregate, Branford quadrangle, Connecticut: U.S. Geol. Survey Misc. Field Studies Map MF-560-B, scale $1: 24,000$.

- 1974, Unconsolidated materials, Branford quadrangle, Connecticut: U.S. Geol. Survey Misc. Field Studies Map MF-560-A, scale 1:24,000. 
Goldsmith, R., 1974, Unconsolidated materials, Montville quadrangle, Connecticut: U.S. Geol. Survey Misc. Field Studies Map MF-580-A, scale $1: 24,000$.

- 1974, Unconsolidated materials, Niantic quadrangle, Connecticut: U.S. Geol. Survey Misc. Field Studies Map MF-593-A, scale 1:24,000.

Haeni, F. P., 1974, Contour map of the bedrock surface, Clinton quadrangle, Connecticut: U.S. Geol. Survey Misc. Field Studies Map MF-553-A, scale $1: 24,000$.

- 1974, Contour map of the bedrock surface, Guilford quadrangle, Connecticut: U.S. Geol. Survey Misc. Field Studies Map MF-583-A, scale $1: 24,000$.

-_ 1974 , Contour map of the bedrock surface, Mount Carmel quadrangle, Connecticut: U.S. Geol. Survey Misc. Field Studies Map MF-540-A, scale $1: 24,000$.

- 1974, Contour map of the bedrock surface, Wallingford quadrangle, Connecticut: U.S. Geol. Survey Misc. Field Studies Map MF-554-A, scale $1: 24,000$.

,- 1975 , Contour map of the bedrock surface, Meriden quadrangle, Connecticut: U.S. Geol. Survey Misc. Field Studies Map MF-661-A, scale $1: 24,000$.

Haeni, F. P., and Sanders, J. E., 1974, Contour map of the bedrock surface, New Haven-Woodmont quadrangles, Connecticut: U.S. Geol. Survey Misc. Field Studies Map MF-557-A, scale 1:24,000.

Handman, E. H., and Ginsberg, M. H., 1975, Depth to bedrock, Mt. Carmel quadrangle, Connecticut: U.S. Geol. Survey Misc. Field Studies Map MF-540-B, scale $1: 24,000$.

Mazzaferro, D. L., 1975, Contour map of the bedrock surface, Southington quadrangle, Connecticut: U.S. Geol. Survey Misc. Field Studies Map MF-660-A, scale $1: 24,000$.

Meade, D. B., and Melvin, R. L., 1974, Contour map of the bedrock surface, Old Lyme quadrangle, Connecticut: U.S. Geol. Survey Misc. Field Studies Map MF-558-A, scale $1: 24,000$.

Naylor, R. G., 1974, Contour map of the bedrock surface, Essex quadrangle, Connecticut: U.S. Geol. Survey Misc. Field Studies Map MF-587-C, scale $1: 24,000$.

,- 1974 , Resources of coarse aggregate, Essex quadrangle, Connecticut: U.S. Geol. Survey Misc. Field Studies Map MF-587-B, scale 1:24,000.

- 1974, Unconsolidated materials, Essex quadrangle, Connecticut: U.S. Geol. Survey Misc. Field Studies Map MF-587-A, scale 1:24,000.

O'Leary, D. W., 1974, Resources of coarse aggregate, Moodus quadrangle, Connecticut: U.S. Geol. Survey Misc. Field Studies Map MF-510-B, scale $1: 24,000$.

- 1974, Unconsolidated materials, Moodus quadrangle, Connecticut: U.S. Geol. Survey Misc. Field Studies Map MF-510-A, scale 1:24,000, 2 sheets.

Thomas, M. P., 1974, Drainage areas, Essex quadrangle, Connecticut: U.S. Geol. Survey Misc. Field Studies Map MF-587-D, scale 1:24,000.

,- 1974 , Drainage areas, Moodus quadrangle, Connecticut: U.S. Geol. Survey Misc. Field Studies Map MF-510-C, scale 1:24,000.

$\longrightarrow$, 1975, Drainage areas, New Haven-Woodmont quadrangle, Connecticut: U.S. Geol. Survey Misc. Field Studies Map MF-557-B, scale 1: 24,000 . 
1975, Drainage areas, Marlborough quadrangle, Connecticut: U.S.

Geol. Survey Misc. Field Studies Map MF-645-B, scale 1:24,000.

-1975 , Drainage areas, Niantic quadrangle, Connecticut: U.S. Geol. Survey Misc. Field Studies Map MF-593-B, scale 1:24,000.

,- 1975 , Drainage areas, Old Lyme quadrangle, Connecticut: U.S. Geol. Survey Misc. Field Studies Map MF-558-C, scale 1:24,000.

Thomas, M. P., and Meade, D. B., 1974, Drainage areas, Deep River quadrangle, Connecticut: U.S. Geol. Survey Misc. Field Studies Map MF542-C, scale $1: 24,000$.

Thomas, M. P., and Palmer, J. E., 1974, Drainage areas, Clinton quadrangle, Connecticut: U.S. Geol. Survey Misc. Field Studies Map MF-553-B, scale $1: 24,000$.

,- 1974 , Drainage areas, Middle Haddam quadrangle, Connecticut: U.S. Geol. Survey Misc. Field Studies Map MF-630-A, scale 1:24,000.

- 1974, Drainage areas, Middle Haddam quadrangle, Connecticut: U.S. Geol. Survey Misc. Field Studies Map MF-630-A, scale 1:24,000.

- 1975, Drainage areas, Branford quadrangle, Connecticut: U.S. Geol. Survey Misc. Field Studies Map MF-560-D, scale 1:24,000.

- 1975, Drainage areas, Guilford quadrangle, Connecticut: U.S. Geol. Survey Misc. Field Studies Map MF-583-B, scale 1:24,000.

$\longrightarrow, 1975$, Drainage areas, Haddam quadrangle, Connecticut: U.S. Geol. Survey Misc. Field Studies Map MF-638-A, scale 1:24,000.

-1975 , Drainage areas, Middletown quadrangle, Connecticut: U.S. Geol. Survey Misc. Field Studies Map MF-639-A, scale 1:24,000.

\section{Title: Puget Sound Urban Area Study (XIII-19)}

Status: Ongoing FY 76

Location: Puget Sound area, Washington

Principal Contact: WA-2

Objective: To provide earth-science and other natural-science information to aid rational land use decisions. The Puget Sound area is one of substantial population growth, sometimes into areas that pose natural hazards to man's use of the land for siting of structures and various works. In addition, recent and expected increases in oil exploration in Alaska and the Gulf of Alaska have affected and will continue to affect land-based activities in the Puget Sound region.

Products :

Bortleson, G. C., and Foxworthy, B. L., 1974 [1975], Relative susceptibility of lakes to water-quality degradation in the southern Hood Canal area, Washington: U.S. Geol. Survey Misc. Inv. Ser. I-853-B, scale $1: 62,500$.

Miller, R. D., 1974, Map showing relative compressibility of earth materials in part of west-central King County, Washington: U.S. Geol. Survey Misc. Inv. Map I-852-C.

Rice, William, 1975, Map showing nonmetallic mineral resources in part of west-central King County, Washington: U.S. Geol. Survey Misc. Inv. Map I-852-D.

Richardson, Donald, 1974, Streamflow in the southern Hood Canal area, Washington, as related to land use planning: U.S. Geol. Survey Misc. Inv. Ser. Map I-853-C.

Tubbs, D. W., 1974, Landslides and associated damage during early 1972 in part of west-central King County, Washington: U.S. Geol. Survey Misc. Geol. Inv. Map I-852-B. 
Title: South Florida Environment Study (XIII-20)

Status: Ongoing FY 76

Location: South Florida

Principal Contact: NR-5

Objective: To synthesize the results of 51 previously completed environmental reports and to serve as background for the development of land management alternatives for the region. This study involved many bureaus of the Department of the Interior and dealt with the relationship between the natural environment of south Florida and man's activities.

Title: History of the Oil and Gas Industry on the Louisiana Coast (XIII-21)

Status: Ongoing FY 76

Location: Louisiana coast

Principal Contact: NR-2

Objective: To study the development and impact of shore facilities such as service bases and associated activities which serve the off shore oil industry. Maps, photographs, and economic and labor statistics from the past 30 years will be reviewed.

Title: Fairfax County, Virginia, Earth-Sciences Applications Study (XIII22)

Status: Ongoing in FY 76

Location: Fairfax County, Virginia

Principal Contact: NR-4

Objective: To provide land use planners and decisionmakers geohydrologic information to aid rational land use decisions. As part of the Nation's capital area, Fairfax County is experiencing a continuing rapid increase in population that is outstripping facilities for providing a water supply and waste-water treatment. Geologic materials in many areas of the county possess characteristics that make them poorly suitable as building foundations, as sources of ground water, or as sites for liquid waste disposal. When presented in carefully chosen formats, geohydrologic information providies land use decisionmakers a documented rationale for land use decisions.

\section{XIV.-EARTH RESOURCES OBSERVATION SYSTEMS (EROS) PROGRAM}

The Earth Resources Observation Systems (EROS) Program, a Department of the Interior program administered by the Geological Survey, in cooperation with the National Aeronautics and Space Administration, the Department of Commerce, and other agencies, is developing, demonstrating, and assisting in the application of remote sensing data acquired from aircraft and spacecraft to aid in the resolution of national and regional issues, among them mineral resource exploration, inventories of renewable natural resources, and environmental monitoring.

Three major areas of activity within EROS are: (1) remotesensing applications demonstration and research, (2) user as- 
sistance and training, and (3) data reproduction and dissemination. Over the past several years research has found many useful applications for Landsat (formerly ERTS) and other remotesensing imagery. Examples of these applications include Statebase photomosiac maps, monitoring of surging glaciers, systematic flood surveys and other disaster surveys, analysis. of vegetation and surface-water features in coastal and interior wetlands, and mapping of volcanoes and faults. Research is continuing in the development of methodologies for automatic cartographic handling of the digital Landsat data on magnetic tape. These procedures enable investigators to extract automatically land cover classes and relate these classes to their coordinate points on the Earth's surface.

The second major focus of the EROS Program is on the training of resource managers, both within the Department of the Interior and from other agencies, in the use of remotely sensed imagery and data. Training is provided in methods of remotesensing data analysis and feature extraction of various resource topics.

The EROS Data Center is the principal outlet for sale of Landsat and other satellite imagery, NASA aerial photography, and USGS aerial photography, both to the public and to other agencies of the Federal Government. Archives through June 1975 include about 600,000 items of satellite imagery, 1,800,000 items of NASA aircraft imagery and 3,600,000 items of aerial photography. Order forms for procuring imagery may be obtained by writing:

\section{EROS Data Center \\ U.S. Geological Survey \\ Sioux Falls, South Dakota 57198}

\section{RELATED ACTIVITIES}

Title: ERTS-1, A New Window on Our Planet (XIV-1)

Status: Ongoing FY 76

Location: Nationwide

Principal Contact: NR-6

Objective: "ERTS-1, a new Window on Our Planet" is a publication which organizes the results of Geological Survey, other agency, and university research utilizing ERTS imagery. A number of the studies cited deal with coastal resources.

Product:

Williams, R. S., Jr., and Carter, W. D., eds., 1976, ERTS-1, a new window on our planet: U.S. Geol. Survey Prof. Paper 929, 362 p. [In press.] 
Title: Optical and Computer Processing and Interpretation Techniques for Landsat Hydrology and Environmental Applications (XIV-2)

Status: Ongoing FY 76

Location: Lake Ontario, New York; southern Alabama; northwest Florida; Santa Barbara Channel, California: Atlantic Ocean area; and Delaware Principal Contact: NR-6

Objective: To demonstrate new hydrologic and environmental applications of Landsat data employing specialized optical reprocessing techniques and analog computer analysis.

Products:

Bukata, R. P., Harris, G. P., and Bruton, J. E., 1974, Detection of suspended solids and chlorophyll A using digital multispectral ERTS-1 data: Proc., Canadian Symposium on Remote Sensing, 2d, Guelph, Ontario 1974, p. 551-564.

Bukata, R. P., Bruton, J. E., Jerome, J. H., Bobba, A. G., and Harris, G. P., 1975, Application of Landsat I digital data to a study of coastal hydrography: Canadian Symposium on Remote Sensing, 3d, Edmonton, Alberta 1975, Proc. p. 331-337.

Title: Detection of Oil in Coastal Waters (XIV-3)

Status: Ongoing FY 76

Location: Offshore Delaware and Santa Barbara Channel, California Principal Contact: NR-6

Objective: To determine whether oil spills and natural oil seeps in coastal areas could be detected on Landsat data. Oil was detected floating on the waters of the Atlantic east of Delaware, the Mediterranean Sea, and the Gulf of Suez. In the latter study, employing digital analysis at full electronic resolution of the analog computer, the drilling platforms in the area of floating oil were detected.

Title: Coastal and Estuarine Flooding Resulting from Tropical Storms (XIV-4)

Status: Ongoing FY 76

Location: Offshore Florida and Alabama

Principal Contact: NR-6

Objective: To determine whether areas of coastal and estuarine flooding resulting from tropical storms could be delineated on Landsat imagery. Inspection of preliminary Landsat data collected over parts of the Gulf of Mexico coastline in Florida and Alabama indicates that a signature of the flooded area can be detected more than 2 weeks after the waters have receded. Development of an operational capability to map coastal and estuarine flooding will be of value in assessment of damages, in delineation of disaster areas for relief, for reconstruction and insurance purposes, and in the engineering design of structures in the affected areas.

Title: Applications of Remote Sensing to the International Field Year for the Great Lakes (IFYGL), International Hydrological Decade (XIV-5) Status: Ongoing FY 76

Location: Lake Ontario Basin, New York

Principal Contact: NR-6

Objective: To determine the utility of remotely sensed data toward meeting the objectives of assessing the water resources, water quality, and 
water dynamics of both the land and water portions of the Lake Ontario Basin of Canada and the United States. Of direct application to coastal zone problems was the demonstrated capability to determine the source, movement, and probable fate of natural and manmade pollutants in the waters of Lake Ontario. The studies employed photographic and thermal data collected from high-flying NASA and Canadian aircraft as well as multispectral scanner data from Landsat.

\section{XV.-REGULATORY RESPONSIBILITIES}

The U.S. Geological Survey is assigned the responsibility for regulating exploration and production of minerals on the Outer Continental Shelf (OCS). The Geological Survey's lease-management mission is concerned with personnel and equipment safety, conservation of resources, and prevention of pollution. Supervision is carried out through a set of rules and regulations that are implemented through field inspections and by review of applications and proposed plans.

The basic law governing these offshore activities is the Outer Continental Shelf Lands Act, Public Law 83-212, enacted in 1953. It establishes Federal jurisdiction over the submerged lands of the OCS and authorizes the Secretary of the Interior to lease such lands for the exploration and development of mineral deposits. Regulations promulgated under the act for leasing OCS lands for oil, gas, and sulfur are contained in Title 43, Part 3300 of the Code of Federal Regulations and are administered by the Bureau of Land Management. Regulations governing drilling and producing operations are found in Titles 30 and 43 of the Code. The operating regulations are applicable to all OCS areas. They are supplemented by OCS Orders which deal specifically with problems unique to a certain area.

The orders and regulations deal with safety and pollution control operations of oil and gas exploration and development, including surface and subsurface well controls, production facility controls, and pipeline controls. Regulations exist covering oil royalty payments and leasing regulations, among others.

Before drilling can be initiated, the lessee must submit an Application for a Permit to Drill, which details the plans for exploration and development and for handling emergencies. This plan is reviewed by the Geological Survey for compliance with orders and regulations.

If exploration is successful and commercially exploitable amounts of hydrocarbons have been located, the lessee must make application to install development drilling rigs and production platforms. These applications are also reviewed to insure that 
the design of the structures and plans for operation are in compliance with safety standards.

Once operation has begun the Geological Survey has the responsibility to inspect, monitor and document the activities and operations of the petroleum industry on the OCS. The inspection procedure seeks to verify that safety controls are in place and are capable of operation. Incidents of noncompliance require that prescribed enforcement actions be taken, which can result in warnings to operators or possible shutdowns of operations. Inspections are also performed to detect and investigate pollution incidents, such as oil spills and accidents on platforms.

\section{RELATED ACTIVITIES}

\section{Title: Outer Continental Shelf (OCS) Orders (XV-1)}

Status: Current FY 76

Location: Federal OCS

Principal Contact: DC-1, LA-2, and CA-2

Objective: Mineral exploration and production on the OCS are conducted under the Code of Federal Regulations supplemented by OCS Orders and Notices issued to lessees and operators. The rules and regulations are frequently reviewed and revised by the public, State and local government, and industry. These rules and regulations reflect changing technology, environmental and safety positions, and standards. These regulations define the responsibility and authority of the Geological Survey to regulate operations, to exercise control over drilling and production, Product: and to require adequate safety equipment.

U.S. Dept. of the Interior, 1975, Regulations pertaining to mineral leasing, operations and pipelines on the OCS as contained in Title 30 and Title 43 of the Code of Federal Regulations and the OCS Lands Act (67 Stat. 462) : Washington, D.C., 1975, OCS Orders 1 through 12 governing oil, gas, and sulfur leases in the OCS Gulf of Mexico area.

\section{XVI.-NATIONAL ENVIRONMENTAL POLICY ACT (NEPA) RELATED ACTIVITIES}

The National Environmental Policy Act (NEPA) of 1969 (Public Law 91-190) is the most comprehensive legislative statement of the Nation's commitment to protect the environment. The act requires that a Federal agency contemplating an action that could significantly affect the quality of the human environment must prepare a detailed statement of the environmental effects of the action. This statement must comprise a description of the proposed action, a description of the existing environment, a discussion of the impacts the proposal will have on the environment, the measures that are available to mitigate or lessen the impacts, the impacts that cannot be avoided, the re- 
sources that will be committed irreversibly and irretrievably by the proposal, a description of available alternatives to the proposal and their environmental impacts, and a discussion of the relationship between the short-term uses of the environment and the maintenance and enhancement of long-term productivity. The act further requires that statements be reviewed by other Federal agencies having pertinent jurisdiction or expertise. In final form, the statement plays an essential role in an agency's decisionmaking process.

The Environmental Impact Analysis Program provides an integrated Geological Survey response to the requirements of the National Environmental Policy Act of 1969. The program (1) provides direction, coordination, and expertise in the preparation of environmental impact statements for which the Geological Survey has lead or joint responsibility; (2) provides technical information and expertise in support of the preparation of statements for which the Geological Survey has contributing responsibility; (3) provides required or requested technical analysis, review, and comment on statements and related documents prepared by other agencies; (4) prepares manuals, guidelines, and training courses on the preparation and review of statements; and (4) stimulates, promotes, and conducts environmental research directly related to the work and anticipated needs of the program.

Currently, the Geological Survey has lead agency responsibility for two environmental impact statements in coastal zone areas. In addition, staff members are contributing expertise to several statements dealing with OCS development in which the Bureau of Land Management has lead responsibility. The review unit of the program annually comments on numerous coastal zone related environmental impact statements.

\section{RELATED ACTIVITIES}

Title: Oil and Gas Development in the Santa Barbara Channel Outer Continental Shelf off California (XVI-1)

Status: Ongoing FY 76

Location: California

Principal Contact: NR-8

Objective: To produce an environmental impact statement to examine impacts of further oil and gas development in the Santa Barbara Channel.

Product:

U.S. Geol. Survey, 1975, Draft environmental statement on oil and gas development in the Santa Barbara Channel Outer Continental Shelf off California: DES $75-35,3$ v. 
Title: Proposed Regulations Pursuant to Geological and Geophysical Explorations in the Outer Continental Shelf (XVI-2)

Status: Ongoing FY 76

Location: Federal Outer Continental Shelf

Principal Contact: NR-8

Objective: To produce an environmental impact statement to examine impacts of proposed regulations governing Outer Continental Shelf geological and geophysical exploration.

Product:

U.S. Geol. Survey, 1975, Draft environmental impact statement on proposed regulations pursuant to geological and geophysical explorations in the Outer Continental Shelf: DES 75-30, 180 p.

INDEXES

PRINCIPAL CONTACT CODE INDEX

Principal contact

Code reference

Harry Hulsing, District Chief

AK-1

Water Resources Division

U.S. Geological Survey

218 "E" Street

Anchorage, Alaska 99501

Lee R. Peterson, District Chief

CA-1

Water Resources Division

U.S. Geological Survey

855 Oak Grove Avenue

Menlo Park, California 94025

Conservation Manager, Western Region

$\mathrm{CA}-2$

U.S. Geological Survey

345 Middlefield Road

Menlo Park, California 94025

Regional Geologist, Western Region

CA-3

U.S. Geological Survey

345 Middlefield Road

Menlo Park, California 94025

Project Director

$\mathrm{CA}-4$

San Francisco Bay Region Study

U.S. Geological Survey

345 Middlefield Road

Menlo Park, California 94025

Regional Geologist, Central Region

$\mathrm{CO}-1$

U.S. Geological Survey

Building 25, Denver Federal Center

Denver, Colorado 80225

Frederick H. Ruggles, Jr., District Chief

CT-1

Water Resources Division

U.S. Geological Survey

Room 235, Post Office Building

135 High Street, PO Box 715

Hartford, Connecticut 06101 
PRINCIPAL CONTACT CODE INDEX-Continued

Principal contact

Code reference

Chief, Connecticut Valley Urban Area Study

CT-2

U.S. Geological Survey

PO Box 470, Main Street

Middletown, Connecticut 06457

Conservation Manager, Eastern Region

DC-1

U.S. Geological Survey

$1725 \mathrm{~K}$ Street, NW, Suite 43

Washington, D.C. 20244

Clyde S. Conover, District Chief

FL-1

Water Resources Division

U.S. Geological Survey

325 John Knox Road

Suite F-240

Tallahassee, Florida 32303

Leslie B. Laird, Regional Hydrologist

GA-1

Water Resources Division, Southeastern Region

U.S. Geological Survey

1459 Peachtree Street, NE

Suite 200

Atlanta, Georgia 30309

Lawrence A. Martins, District Chief

IL-1

Water Resources Division

U.S. Geological Survey

605 N. Neil Street, PO Box 1026

Champaign, Illinois 61820

James L. Cook, District Chief

IN-1

Water Resources Division

U.S. Geological Survey

1819 North Meridian Street

Indianapolis, Indiana 46202

Albert N. Cameron, District Chief

LA-1

Water Resources Division

U.S. Geological Survey

PO Box 66495

6554 Florida Blvd.

Baton Rouge, Louisiana 70806

Conservation Manager, Gulf of Mexico Operations

LA-2

U.S. Geological Survey

PO Box 7944

Metairie, Louisiana 70011

John A. Baker, District Chief

MA-1

Water Resources Division

U.S. Geological Survey

150 Causeway Street, Suite 1001

Boston, Massachusetts 02114 
PRINCIPAI CONTACT CODE INDEX-Continued

Principal contact

Code reference

Walter F. White, District Chief

MD-1

Water Resources Division

U.S. Geological Survey

8809 Satyr Hill Road

Parkville, Maryland 21234

Ray T. Cummings, District Chief

MI-1

Water Resources Division

U.S. Geological Survey

2400 Science Parkway

Okemos, Michigan 48864

Charles R. Collier, District Chief

$\mathrm{MN}-1$

Water Resources Division

U.S. Geological Survey

1033 Post Office Building

St. Paul, Minnesota 55101

Lamar E. Carroon, District Chief

MS-1

Water Resources Division

U.S. Geological Survey

430 Bounds Street

Jackson, Mississippi 39206

Ralph C. Heath, District Chief

NC-1

Water Resources Division

U.S. Geological Survey

PO Box 2857, Room 440, Century Sta.

Post Office Building

Raleigh, North Carolina 27602

Harold Meisler, District Chief

NJ-1

Water Resources Division

U.S. Geological Survey

PO Box 1238, Room 420, Federal Bldg.

402 East State Street

Trenton, New Jersey 08607

Joseph T. Callahan, Regional Hydrologist

NR-1

Water Resources Division, Northeastern Region

U.S. Geological Survey

433 National Center

Reston, Virginia 22092

James R. Anderson, Chief, Geography Program

NR-2

U.S. Geological Survey

710 National Center

Reston, Virginia 22092

Chief, Baltimore-Washington Urban Area Study

NR-3

U.S. Geological Survey

720 National Center

Reston, Virginia 22092 
PRINCIPAL CONTACT CODE INDEX-Continued

Principal contact

Code reference

Chief, Fairfax County Earth Sciences Applications Study _..- NR-4

U.S. Geological Survey

926 National Center

Reston, Virginia 22092

J. Ronald Jones, Chief, Resource and Land

NR-5

Investigations Program

U.S. Geological Survey

750 National Center

Reston, Virginia 22092

John M. DeNoyer, Chief, Earth Resources

NR-6

Observation Systems Program

U.S. Geological Survey

1925 Newton Square, East

Reston, Virginia 22090

Regional Geologist, Eastern Region

NR-7

U.S. Geological Survey

953 National Center

Reston, Virginia 22092

Herbert G. Stewart

NR-8

Special Assistant for Environmental Analysis

Office of the Director

U.S. Geological Survey

108 National Center

Reston, Virginia 22092

Robert J. Dingman, District Chief

NY-1

Water Resources Division

U.S. Geological Survey

PO Box 1350

343 Post Office \& Court House

Albany, New York 12201

Stanley F. Kapustka, District Chief

OR-1

Water Resources Division

U.S. Geological Survey

PO Box 3202

830 NE Holladay Street

Portland, Oregon 97208

Norman H. Beamer, District Chief

Water Resources Division

U.S. Geological Survey

PO Box 1107, 4th Floor, Federal Bldg.

228 Walnut Street

Harrisburg, Pennsylvania 17108

John S. Stallings, District Chief

SC-1

Water Resources Division

U.S. Geological Survey

2001 Assembly Street, Suite 200

Columbia, South Carolina 29201 
PRINCIPAL CONTACT CODE INDEX-Continued

Principal contact

Chief, Topographic Division

TD-1

U.S. Geological Survey

516 National Center

Reston, Virginia 22092

Chief, Eastern Mapping Center

TD-2

U.S. Geological Survey

567 National Center

Reston, Virginia 22092

Chief, Mid-Continent Mapping Center

TD-3

U.S. Geological Survey

USGS Building

1400 Independence Road

Rolla, Missouri 65401

Chief, Rocky Mountain Mapping Center

TD-4

U.S. Geological Survey

Topographic Division (510)

Box 25046, Denver Federal Center

Denver, Colorado 80225

Chief, Western Mapping Center

TD-5

U.S. Geological Survey

345 Middlefield Road

Menlo Park, California 94025

Dale I. Yost, District Chief

$\mathrm{TX}-1$

Water Resources Division

U.S. Geological Survey

630 Federal Building

300 East 8th Street

Austin, Texas 78701

William E. Forrest, District Chief

VA-1

Water Resources Division

U.S. Geological Survey

200 West Grace Street

Room 304

Richmond, Virginia 23220

Chief, Puget Sound Urban Area Study

WA-2

U.S. Geological Survey

Room 210

1305 Tacoma Avenue South

Tacoma, Washington 98402

C.L.R. Holt, Jr., District Chief

WI-1

Water Resources Division

U.S. Geological Survey

1815 University Avenue

Room 200

Madison, Wisconsin 53700 


\section{PRINCIPAL CONTACT CODE INDEX-Continued}

Principal contact

Code reference

Regional Hydrologist, Western Region

WR-1

Water Resources Division

U.S. Geological Survey

345 Middlefield Road

Menlo Park, California 94025

Edward A. Moulder, Asst. Chief Hydrologist,

WRD-1

Research and Technical Coordination

Water Resources Division

U.S. Geological Survey

414 National Center

Reston, Virginia 22092

\section{STATE INDEX}

All projects occurring within a State's boundaries or in offshore waters are indexed. Index numbers refer to project descriptions in the text. In addition, figures 2 through 14 show the status of topographic and land use mapping in the coastal States and Territories.

Alaska: I-3, 5; II-1-3, 19-31; III-10-14; IV-1-2; V-1; VI-1-3; VII-1-4, 7-10; VIII-8-9, 13-16; IX-1; X-1-2; XI-1; XII-1-5, 8-12; XIII-1-12; XIV-1; XV-1; XVI-2.

Alabama: I-1, 5; II-1-2, 14; III-5, 8; VI-1-4; VII-1-3; VIII-1-3, 5-6; IX-1, 3; X-1-2; XI-1; XII-1-4; XIII-1-12; XIV-1-2, 4 ; XV-1; XVI-2.

California : I-4-5; II-1, 16, 32-37; III-10-11, 15-16; IV-3-15 ; V-2-7; VI-1-3, 5-8; VII-1-4; VIII-8-9, 11-12, 17-19; IX-1, $4-6$; X-1-2; XI-1-4; XII-1-3, 13-14; XIII-1-12, 14, 17; XIV-1-3; XV-1; XVI-1-2.

Connecticut: I-1, 5; II-1-7 ; III-1-2, 17; VI-1-4 ; VII-1-3 ; VIII-1-2; IX-1; X-1-2, 4; XI-1; XII-1-4, 6, 15-16; XIII$1-13,18 ; \mathrm{XIV}-1-2 ; \mathrm{XV}-1 ; \mathrm{XVI}-2$.

Delaware: I-1, 5; II-1-6, 8-9; III-1-4; VI-1-4; VII-1-3; VIII1 ; IX-1-2; X-1-3; XI-1; XII-1-4; XIII-1-12, 15; XIV-1-3; $\mathrm{XV}-1 ; \mathrm{XVI}-2$.

Florida : I-1, 5; II-1-6, 11-12, 14, 38; III-1-2, 4, 6, 8-9; VI-1-5; VII-1-3, 5-6, 11; VIII-1, 3-6, 20-24; IX-1-3, 7-33; X-1-2, 5 ; XI-1, 5-9; XII-1-4, 17-25; XIII-1-12, 20 ; XIV-1-2, 4; XV-1; XVI-2. 
Georgia, I-1, 5-6; II-1-6 ; 11-12;III-1-2, 4, 6, 8-9; IV-17; VI-1-4; VII-1-3, 6 ; VIII-1, 3 ; IX-1; X-1-2; XI-1; XII$1-4 ;$ XIII-1-12; XIV-1-2; XV-1; XVI-2.

Hawaii : I-1-5; II-1; IV-16; VI-1-3; VII-1-2; IX-1; X-1-2; XI-1; XII-1-4; XIII-1-12; XIV-1.

Illinois: I-2, 5; II-2; III-18; VI-1-3; VII-1-2; IX-1; X-1-2, 6; XI-1; XII-1-4; XIII-1-12; XIV-1.

Indiana: I-1, 5; II-1; VI-1-3; VII-1-2; IX-1; X-1-2; XI-1, 10; XII-1-4, 7, 26; XIII-1-12; XIV-1.

Louisiana: I-2, 5 ; II-1-2, 12-15, 39, 40 ; III-8; VI-1-4 ; VII-1-3 ; VIII-1, 3-7; IX-1-3; X-1-2; XI-1; XII-1-4, 27-28; XIII$1-12,21 ; \mathrm{XIV}-1$; XV-1; XVI-2.

Maine: I-1, 5 ; II-1-7; III-1-2, 10, 19-20; VI-1-4; VII-1-3, 5; VIII-1-2; IX-1, 34; X-1-2; XI-1; XII-1-4; XIII-1-13; XIV-1-2; XV-1; XVI-2.

Maryland: I-1, 5; II-1-6, 8-9; III-1-4, 6, 7-9, 21; VI-1-4; VII-1-3, 5; VIII-1, 25 ; IX-1, 35; X-1-2; XI-1; XII-1-4; XIII-1-12, 15-16; XIV-1-2; XV-1; XVI-2.

Massachusetts : I-1, 5; II-1-7; III-1-4, 22; V-8-9; VI-1-4; VII-1-4; VIII-1, 26; IX-1, 36; X-1-2; XI-1; XII-1-4, 29; XIII-1-14; XIV-1-2; XV-1; XVI-2.

Michigan:I-1-2, 5 ;II-1;III-23; VI-1-3, 5;VII-1-2 ; IX-1, 37-38; X-1-2, 7; XI-1; XII-1-4, 7, 30-31; XIII-1-12; XIV-1.

Minnesota: I-2, 5; II-1; VI-1-3; VII-1-2; IX-1; X-1-2; XI-1; XII-1-4, 32-33; XIII-1-12; XIV-1.

Mississippi : I-2, 5 ; II-1-2, 14 ; III-5, 8; VI-1-4; VII-1-3; VIII$1,3-6$; IX-1-3; X-1-2, 8; XI-1, 11; XII-1-4, 34; XIII-1-12; $\mathrm{XIV}-1 ; \mathrm{XV}-1 ; \mathrm{XVI}-2$.

New Hampshire: I-1, 5; II-1-7; III-1-2; VI-1-4; VII-1-3; VIII-1-2; IX-1; X-1-2; XI-1; XII-1-4; XIII-1-13; XIV$1-2 ; \mathrm{XV}-1 ; \mathrm{XVI}-2$.

New Jersey: I-1, 5; II-1-6, 8-9; III-1-5, 7; VI-1-5; VII-1-4; VIII-1, 27; IX-1-2, 39-42; X-1-3, 9; XI-1; XII-1-4; XIII$1-12,15 ;$ XIV-1-2; XV-1; XVI-2.

New York: I-1, 5 ; II-1-6; III-1-4; VI-1-5; VII-1-3, 5 ; VIII$1-2,28$; IX-1, 43-50; X-1-3, 10-14; XI-1, 12; XII-1-6, 35-38; XIII-1-12; XIV-1-2, 5; XV-1; XVI-2.

North Carolina: I-1, 5; II-1-6, 11, 41; III-1-4, 6-9; VI-1-4; VII-1-3, 5-6; VIII-1, 29-30; IX-1; X-1-2; XI-1; XII-1-4, $39-40 ; \mathrm{XIII}-1-12 ; \mathrm{XIV}-1-2 ; \mathrm{XV}-1 ; \mathrm{XVI}-2$. 
Ohio: I-1, 5; II-1; VI-1-3; VII-1-2; IX-1; X-1-2; XI-1; XII$1-4,7 ;$ XIII-1-12; XIV-1.

Oregon: I-4-5; II-1, 16-18; III-10-12; VI-1-3; VII-1-3, 12; VIII-8-12; IX-1, 51; X-1-2; XI-1-2, 13; XII-1-4, 41; XIII-1-12; XIV-1; XV-1; XVI-2.

Pennsylvania: I-1, 5; II-1; VI-1-3; VII-1-2; IX-1-2, 52; $\mathrm{X}-1-3,12$; XI-1; XII-1-4; XIII-1-12; XIV-1.

Puerto Rico: I-1, 5; II-1-10; III-24; VI-1-3; VII-1-2; VIII-31.

Rhode Island: I-1, 5 ; II-1-7; III-1-2; VI-1-4; VII-1-3; VIII-1; IX-1; X-1-2; XI-1; XII-1-4; XIII-1-13; XIV-1-2; $\mathrm{XV}-1 ; \mathrm{XVI}-3$.

South Carolina: I-1, 5; II-1-6, 11; III-1-2, 4-6, 8-9; IV-17-19; VI-1-4; VII-1-3, 6 ; VIII-1, 3, 32; IX-1, 53; X-1-2, 15; XI-1; XII-1-4, 42; XIII-1-12; XIV-1-2; XV-1; XVI-2.

Texas : I-3, 5 ; II-1-2, 13-15, 42-43; VI-1-5; VII-1-4; VIII-1, $3-7,33-34$; IX-1-3, 54-61; X-1-2, 16; XI-1; XII-1-4; XIII-1-12; XIV-1; XV-1; XVI-2.

Virginia : I-1, 5; II-1-6, 11; III-1-4, 6-9; VI-1-4; VII-1-3, 13; VIII-1; IX-1, 62-64; X-1-2; XI-1; XII-1-4; XIII-1-12, 15,$22 ; \mathrm{XIV}-1-2 ; \mathrm{XV}-1$; XVI-2.

Virgin Islands: I-1, 5; II-1, 10; VI-1-3; VII-1-3.

Washington: I-4-5; II-1, 16-18; III-10-12, 25 ; VI-1-3, 5 ; VII$1-3$; VIII-8-12, 35; IX-1, 65-67; X-1-2; XI-1 ; XII-1-4, 43; XIII-1-12, 19; XIV-1; XV-1; XVI-2.

Wisconsin: I-2, 5; II-1; VI-1-3; VII-1-2; IX-1, 68-70; X-1-2, 17 ; XI-1, 14-16; XII-1-4, 44-46; XIII-1-12; XIV-1.

\section{REFERENCES CITED}

U.S. Department of Commerce, National Oceanic and Atmospheric Administration, 1975, Coastal zone management program administrative grants: notice of final rulemaking. Federal Register, v. 40, no. 6, part 1, Washington, D.C., p. 1683-1695.

Pritchard, D. W., 1967, What is an estuary?, in Lauff, G. H., ed., Estuaries: Washington, D.C., Am. Assoc. Adv. Sci., pub. 83, p. 3-5.

Senate Committee on Commerce, 1975a, Coast zone management act amendments of 1975: Report of the Senate Committee on Commerce on S586: Washington, D.C., U.S. Government Printing Office, 70 p.

$1975 \mathrm{~b}$, Energy facility siting in coastal areas: Washington, D.C., U.S. Government Printing Office, 126 p. 